\title{
Comparison of Large Central and Small Decentralized Power Generation in India
}

Antares Group, Inc. Landover, Maryland

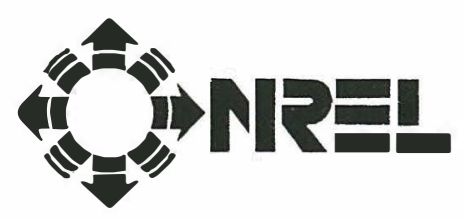

National Renewable Energy Laboratory 1617 Cole Boulevard Golden, Colorado 80401-3393

A national laboratory of the U.S. Department of Energy Operated by Midwest Research Institute for the U.S. Department of Energy

Under Contract No. DE-AC36-83CH10093 


\section{Comparison of Large Central} and Small Decentralized Power Generation in India

\section{Technical Monitor: Ralph Overend}

Antares Group, Inc.

Landover, Maryland

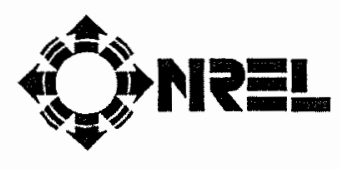

National Renewable Energy Laboratory 1617 Cole Boulevard

Golden, Colorado 80401-3393

A national laboratory of the U.S. Department of Energy Operated by Midwest Research Institute for the U.S. Department of Energy

Under Contract No. DE-AC36-83CH10093

Prepared under Subcontract Number KAP-4-1-14083-06

May 1997 


\section{NOTICE}

This report was prepared as an account of work sponsored by an agency of the United States govemment. Neither the United States govemment nor any agency thereof, nor any of their employees, makes any warranty, express or implied, or assumes any legal liability or responsibility for the accuracy, completeness, or usefulness of any infomation, apparatus, product, or process disclosed, or represents that its use would not infringe privately owned rights. Reference herein to any specific commercial product, process, or service by trade name, trademark, manufacturer, or otherwise does not necessarily constitute or imply its endorsement, recommendation, or favoring by the United States govemment or any agency thereof. The views and opinions of authors expressed herein do not necessarily state or reflect those of the United States govermment or any agency thereof.

Available to DOE and DOE contractors from:

Office of Scientific and Technical Information (OSTI)

P.O. Box 62

Oak Ridge, TN 37831

Prices available by calling (423) 576-8401

Available to the public from:

National Technical Information Service (NTIS)

U.S. Department of Commerce

5285 Port Royal Road

Springfield, VA 22161

(703) $487-4650$ 


\section{Acknowledgments}

The authors wish to thank Gary Burch, Director of the Biomass Power Program at the U.S. Department of Energy, and Kevin Craig, our technical manager at the National Renewable Energy Laboratory, for continuing to sponsor our work. We would also like to acknowledge the assistance of Chuck Kovarik, Peter McCallum, and Tom Perrot for their technical review and assistance in the collection of the data required to assemble this report.

Christian P. Demeter

Christopher A. Lindsey

Pallavi R. Shah 


\section{Executive Summary}

India is the second largest market in the world for new electricity capacity. Its total electricity consumption is expected to increase by $223 \%$ from 1995 to $2020 .{ }^{1}$ In comparison, electricity consumption during the same period in the Organization for Economic and Cooperative Development Countries is expected to increase by only $58 \% .^{2}$ Currently, most of India's electricity consumers are in metropolitan areas; however, approximately $75 \%$ of the population lives in rural areas. This sector has benefited from the government's rural electrification programs, but most villages still face recurrent power shortages and some have no access to power. As a result, there is a substantial potential market for supplying reliable power to rural consumers.

A variety of issues affect India's rural electricity demand, including economic development, power reliability, and environmental concerns. Distributed generation (DG) systems may represent one way of addressing these matters. Although many of the forecasted increases in electricity demand will probably be met by grid extension, there are rural communities in areas where grid extension is uneconomical or technically impractical. DG systems may improve the reliability of India's electricity infrastructure. Increased reliability can stimulate job creation and productivity, and improve the quality of life. In India specifically, reliability may help reduce agricultural subsidies that will strengthen the State Electricity Boards (SEBs). Reducing agricultural subsidies will generate more revenue for the SEBs, which will allow them to:

- $\quad$ Build a pricing structure that better matches the true cost of production

- $\quad$ Meet rising demand

- $\quad$ Save $\$ 29$ million if only $1 \%$ of the current effective subsidy is eliminated.

Biomass DG systems also:

- Help avoid transmission and distribution losses

- $\quad$ Create job and diversity in the agricultural economy through use of biomass fuel

- Benefit the environment by using biomass fuel.

In addition to discussing these issues, this report quantitatively compares four biomass-based DG technologies and a central grid 1,200-MW coal-fired station. The comparison focuses on calculating the costs of electricity (COE) for a Stirling engine, direct-fired combustion turbine, fuel cell, and biomass integrated gasification combined cycle. The results of the COE comparison between the biomass DG systems and the coal-fired central grid station were encouraging; they demonstrated that the technologies may be able to produce very competitively priced electricity by the start of the next century. Eventually, the technologies may experience sufficient cost reductions through production progress and manufacturing economies to make a significant impact on India's power generation mix and expand their marketability into other Asian countries.

The use of DG technology may provide a practical means of addressing many rural electricity issues that India will face in the future. Biomass DG technologies in particular offer unique advantages for the environment and for economic development that will make them especially attractive.

\footnotetext{
${ }^{1}$ DRIMcGraw Hill, 1996, The Future of the Electric Power Industry, p. 112.

${ }^{2}$ EIA, 1996, International Energy Outlook 1996.
} 


\section{Contents}

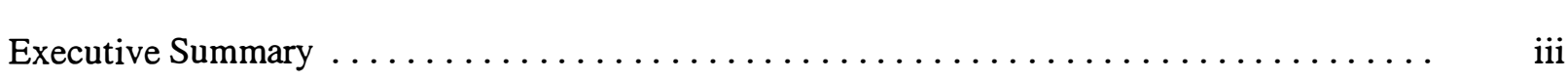

List of Exhibits $\ldots \ldots \ldots \ldots \ldots \ldots \ldots \ldots \ldots \ldots \ldots \ldots \ldots \ldots \ldots \ldots \ldots \ldots \ldots \ldots$

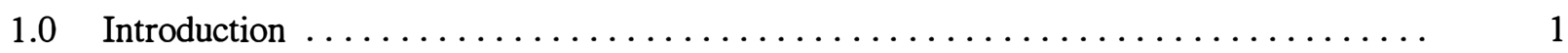

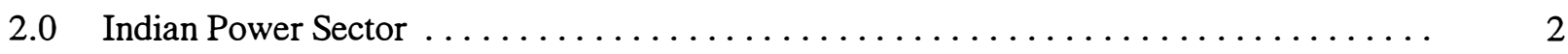

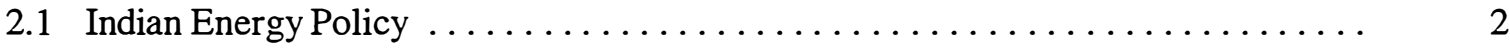

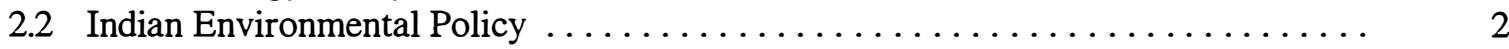

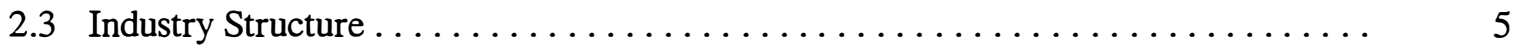

2.4. Current Demand and Forecast Growth $\ldots \ldots \ldots \ldots \ldots \ldots \ldots \ldots \ldots \ldots \ldots \ldots \ldots \ldots \ldots \ldots \ldots$

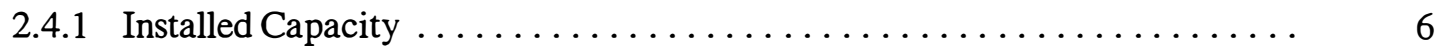

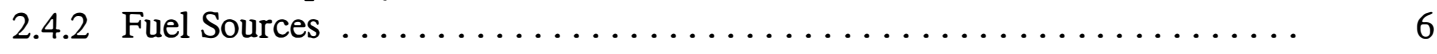

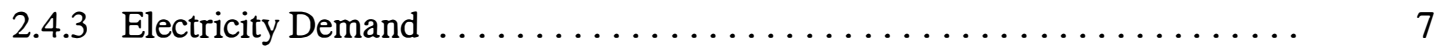

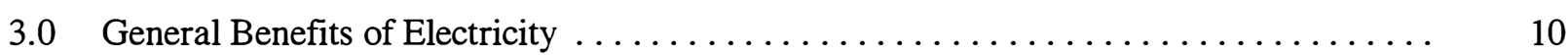

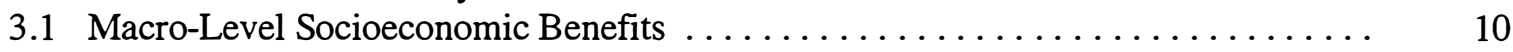

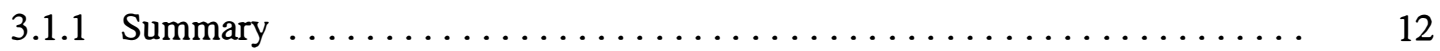

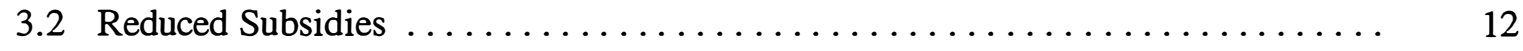

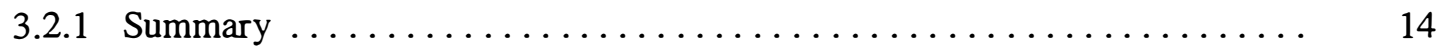

4.0 Benefits of DG Technology Using Biomass $\ldots \ldots \ldots \ldots \ldots \ldots \ldots \ldots \ldots \ldots \ldots \ldots$

4.1 Decentralized Power . . . . . . . . . . . . . . . . . . . . . . . 15

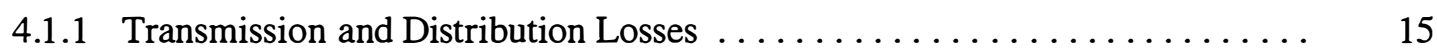

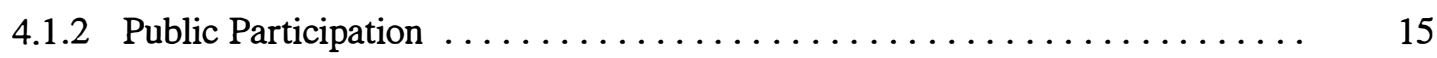

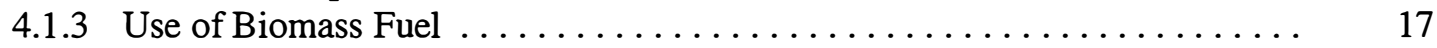

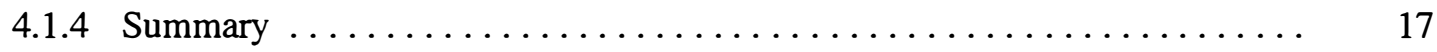

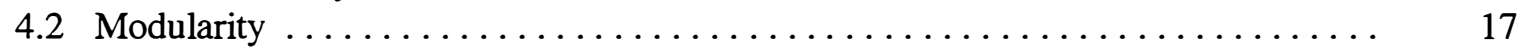

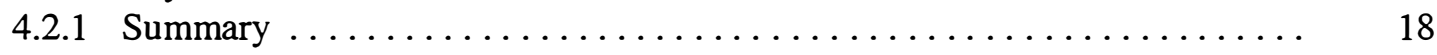

5.0 Benefits of Central Grid Coal-Fired Power Plant $\ldots \ldots \ldots \ldots \ldots \ldots \ldots \ldots \ldots \ldots \ldots$

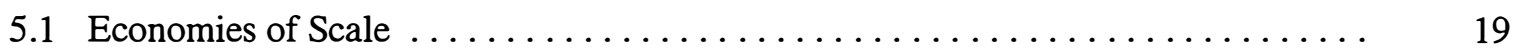

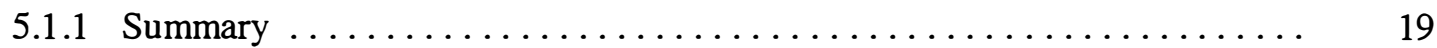

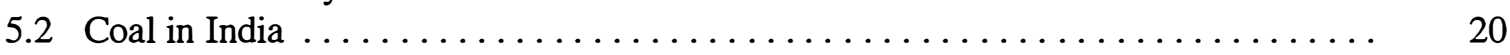

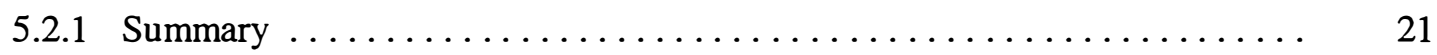

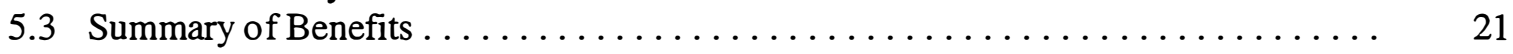

6.0 Biomass Distributed Generation Technologies Description $\ldots \ldots \ldots \ldots \ldots \ldots \ldots \ldots . \ldots \ldots$

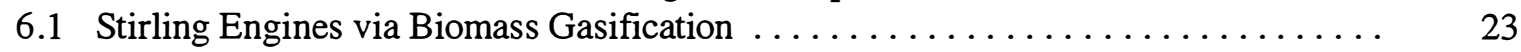

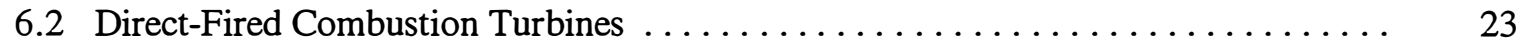

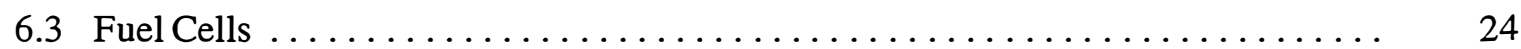

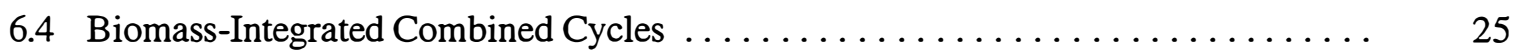

7.0 Cost of Electricity Comparison: DG versus Central Grid $\ldots \ldots \ldots \ldots \ldots \ldots \ldots \ldots$

7.1 Cost of Electricity: Description of Components . . . . . . . . . . . . . . 26

7.2 Assumptions That Affect Capital Cost Calculations for COE Analysis . . . . . . . . 27

7.2.1 Learning/Progress Curves, Economies of Production and Scale . . . . . . . 27

7.2.2 Estimates of Biomass DG Plant Construction Costs ............. 34

7.2.3 Capital Costs in COE Analysis . . . . . . . . . . . . . . . . . 35 


\section{Contents \\ (continued)}

Page

7.3 Assumptions That Affect O\&M Cost Calculations $\ldots \ldots \ldots \ldots \ldots \ldots \ldots \ldots \ldots \ldots$

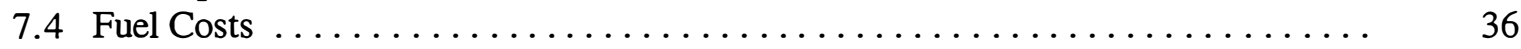

7.5 Transmission and Distribution Costs, Load Profiles, and Capacity Factors . . . . . . 37

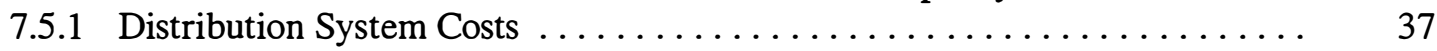

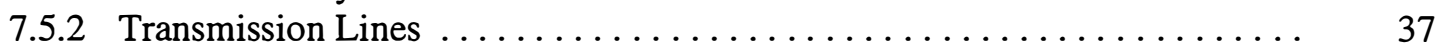

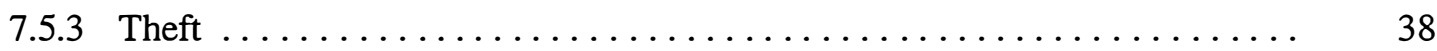

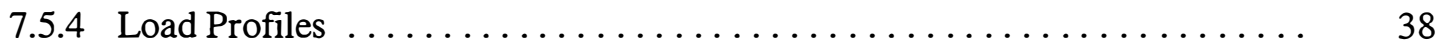

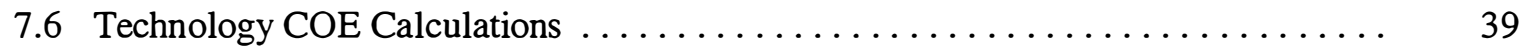

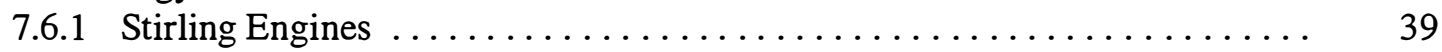

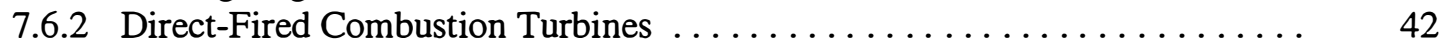

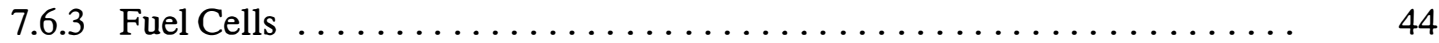

7.6.4 Biomass Integrated Gasification Combined Cycles $\ldots \ldots \ldots \ldots \ldots \ldots \ldots .47$

7.7 Assumptions Used in Coal Plant Analysis . . . . . . . . . . . . . . . . 49

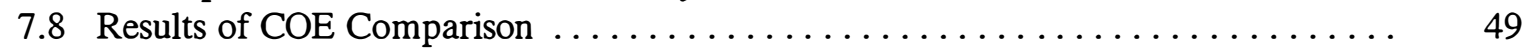

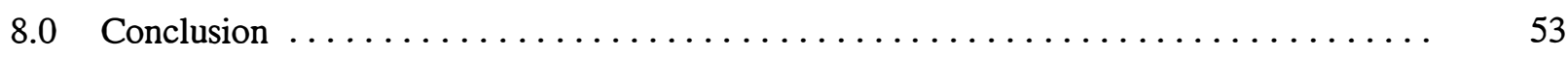

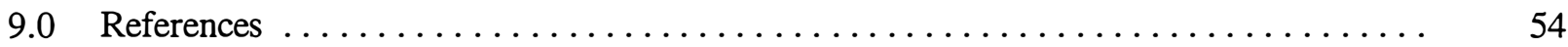

Appendix A: Assumptions and Calculations of Relevant Plant Costs 57

Appendix B: Cost of Electricity Sensitivities $\quad 74$ 


\section{List of Exhibits}

Page

Exhibit 2.2-1 Environmental Regulations in India $\ldots \ldots \ldots \ldots \ldots \ldots \ldots \ldots \ldots \ldots$

Exhibit 2.4-1 Types of Fuel Used to Generate Power in India . . . . . . . . . . . . 6

Exhibit 2.4-2 Sectoral Breakdown of Electricity Consumption for FY 1995-1996 . . . . . 8

Exhibit 3.2-1 Average Electricity Tariff Charged by State Electricity Boards $\ldots \ldots \ldots \ldots$

Exhibit 4.1-1 T\&D Losses as a Percentage of Availability $(1995 / 96) \ldots \ldots \ldots \ldots \ldots \ldots$

Exhibit 6.0-2 Summary of Economic Size Ranges for Each Technology . . . . . . . . 22

Exhibit 6.1-1 Sunpower Incorporated Biomass Stirling Engine $\ldots \ldots \ldots \ldots \ldots \ldots \ldots \ldots$

Exhibit 6.1-2 Stirling Thermal Motors Schematic of BioStirling Engine . . . . . . . . 23

Exhibit 6.2-1 BIOTEN Direct-Fired Combustion Turbine $\ldots \ldots \ldots \ldots \ldots \ldots \ldots \ldots \ldots .23$

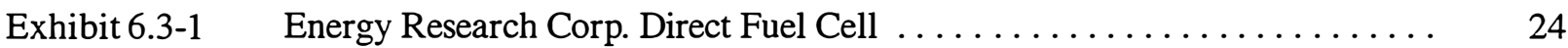

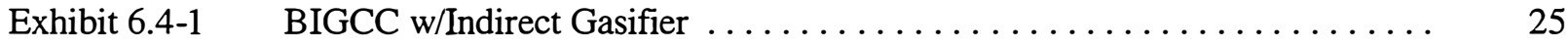

Exhibit 7.5-1 Schematic of Relationship between Power Generation Systems and

T\&D System ................................... 36

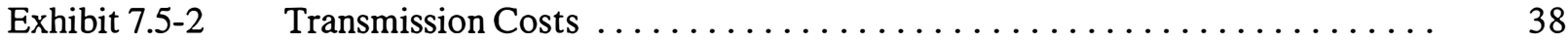

Exhibit 7.6-1 Capital Cost Assumption Summary-Stirling Engine . . . . . . . . . . . 41

Exhibit 7.6-2 Operating Cost Assumption Summary-Stirling Engine $\ldots \ldots \ldots \ldots \ldots .41$

Exhibit 7.6-3 Performance Assumption Summary-Stirling Engine . . . . . . . . . . . . 42

Exhibit 7.6-4 Average Costs and Efficiencies of Small Gas Turbines . . . . . . . . . . 43

Exhibit 7.6-5 Capital Cost Assumption Summary-Direct-Fired Combustion Turbine . . . . 43

Exhibit 7.6-6 Operating Cost Assumption Summary-Direct-Fired Combustion Turbine . . 44

Exhibit 7.6-7 Performance Assumption Summary—Direct-Fired Combustion Turbine . . . . 44

Exhibit 7.6-8 Capital Cost Assumption Summary_Fuel Cell . . . . . . . . . . 45

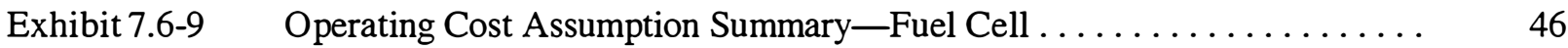

Exhibit 7.6-10 Performance Assumption Summary_Fuel Cell . . . . . . . . . . . 46

Exhibit 7.6-11 Capital Cost Assumption Summary-BIGCC $\ldots \ldots \ldots \ldots \ldots \ldots \ldots \ldots$

Exhibit 7.6-12 Operating Cost Assumption Summary_BIGCC $\ldots \ldots \ldots \ldots \ldots \ldots \ldots \ldots \quad 48$

Exhibit 7.6-13 Performance Assumption Summary_BIGCC . . . . . . . . . . . . . . 49

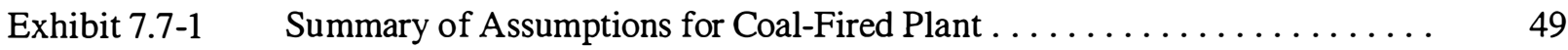

Exhibit 7.8-1 Cost of Electricity Analysis: Stirling Engine Summary of Results . . . . . . 50 
Exhibit 7.8-2 Cost of Electricity Analysis: Direct-Fired CT Summary of Results . . . . . 50

Exhibit 7.8-3 Cost of Electricity Analysis: MCFC Summary of Results . . . . . . . 51

Exhibit 7.8-4 Cost of Electricity Analysis: BIGCC Summary of Results . . . . . . . . 52 


\subsection{Introduction}

India is the second largest market in the world for new electricity capacity. Its total electricity consumption is expected to increase by $223 \%$ from 1995 to $2020 .^{3}$ In comparison, electricity consumption during the same period in the Organization for Economic Cooperation and Development (OECD) countries is expected to increase by only 58\%. ${ }^{4}$ Currently, most of India's electricity consumers are in metropolitan areas; however, approximately $75 \%$ of the population lives in rural areas. This sector has benefited from the government's rural electrification programs, but most villages still face recurrent power shortages, and some have no access to power. As a result, there is a substantial potential market for supplying reliable power to rural consumers.

India is a strong market for renewable power because it benefits from central government-supported institutions, policies, and financial incentives for renewable power. Its Ministry of Non-conventional Energy Sources is offering private power sector companies study grants, negotiable financial support, tax holidays, and lowimpact tariffs to develop wind farms, hydroelectric units, cogeneration units, and other alternative power generation stations.

This report focuses on two specific options. It discusses the benefits and costs of providing reliable power to rural areas with biomass-based distributed generation (DG) systems versus a 1,200-MW central grid coal-fired power plant. The Indian power sector has traditionally relied on central grid coal plants, but their inability to adequately service the rural areas warrants such a comparison. The biomass-based DG systems are examined both as alternatives to grid extension and as supplements to central grid power. The central grid plant is assumed to be a newly built, Nth plant design, tumkey unit.

The benefits are divided into three categories: those associated with providing reliable power from any source; those associated specifically with biomass-based DG technology; and benefits of a central grid coal plant. They are discussed more qualitatively because local-level economic data are limited. The remainder of this report compares the estimated delivered costs of electricity (COEs) from the DG systems to those of the central grid plant. Delivered costs comprise capital costs, operations and maintenance (O\&M) costs, fuel costs, and transmission and distribution (T\&D) costs. The analysis includes estimates for a central grid coal plant and four potential DG system technologies: Stirling engines, direct-fired combustion turbines, fuel cells, and biomass integrated gasification combined cycles (BIGCCs).

\footnotetext{
${ }^{3}$ DRIMcGraw Hill, 1996, The Future of the Electric Power Industry, p.112.

${ }^{4}$ EIA, 1996, International Energy Outlook 1996.
} 


\subsection{Indian Power Sector}

\subsection{Indian Energy Policy}

To date, the Indian government's energy strategies have focused on energy security, energy conservation, and substituting coal for oil. Broadly speaking, its objectives are to':

- $\quad$ Reduce dependence on energy imports by devoting one-third of total Five-Year Plan outlays to developing indigenous energy resources

- Allocate energy equitably, to ensure the equitable development of all regions in India and to safeguard the basic needs of the poor

- Control energy industries, to provide energy to the industrial sector and other sectors at low prices.

The government's energy pricing policies are considered to be a primary obstacle to improving energy efficiency in India. Its pricing rules include 6

- Cost-plus pricing, an administered pricing system that offers little incentive to improve energy efficiency

- $\quad$ Retention pricing system, in which the government allows enterprises to achieve a financial rate of retum of $12 \%$ after tax; through this cross-subsidy system, the government collects taxes from profitable enterprises and subsidizes high-cost enterprises

- Social price subsidies to promote rural electrification, which has been accompanied by low tariffs and poor payment collection from rural households.

Pricing policies are usually implemented at the state level. States charge higher tariffs to their commercial and industrial customers, so they can subsidize agricultural and residential customers. Although most states have similar cross-subsidy structures, some policies and incentives vary from state to state. This adds to the complexity of private power development. For example, Kamataka offers a 5-year electricity tax exemption for captive use, whereas the state of Uttar Pradesh offers no electricity tax exemptions. ${ }^{7}$ Understanding the variety of institutional structures is an important aspect of power project development.

\subsection{Indian Environmental Policy}

India's modem environmental philosophy centers around globalization and equity. With a growing emphasis on sustainable development, countries are realizing that their actions have far-reaching implications. In such a global society, the members are beneficiaries of both state and international law, and international law sometimes takes precedence. The consensus is that underdevelopment in countries such as India was a by-product of the imperial colonies' development. ${ }^{8}$ Developing countries therefore insist on the freedom to find their own

\footnotetext{
5 Ishiguro and Akiyama, 1995, Energy Demand in Five Major Asian Developing Countries: Structure and Prospects, pp.33-34.

6 Ibid, pp.35-6.

${ }^{7}$ NBIA, 1995, p.10.

${ }^{8}$ Pathak, R.S., "Intemational Trade and Environmental Development: A View from India," p.5.
} 
balance of sustainability between the environment and development. India's environmental regulations exemplify a developing country's attempt to find this harmony.

The Indian Constitution was amended in 1976 to include Article 48, which obliges the State to "endeavor to protect and improve the environment and to safeguard the forests and wildlife of the country," and Article 51, which imposes a duty on every Indian citizen to "protect and improve the natural environment including forests, lakes, rivers and wildlife, and to have compassion for living creatures." Exhibit 2.2-1 lists India's main environmental legislative acts. ${ }^{10}$

In addition to these regulations, the Indian government declared several policy initiatives: The National Forest Policy (1988); National Wild Life Action Plan; Forest (Conservation) Act (1988); Policy Statement for the Abatement of Pollution (1992); National Conservation Strategy and Policy Statement on Environment and Development (1992); and miscellaneous initiatives that include the cleaning of rivers, urban housing, land use, and recycling of wastes. ${ }^{11}$ Rural power systems that use biomass are one way of combining the twin objectives of environmental protection and development.

\footnotetext{
${ }^{9}$ Pathak, R.S., p.2.

${ }^{10}$ Pathak, R.S., pp.2-3.

${ }^{11}$ Pathak, R.S., p.4.
} 
Exhibit 2.2-1. Environmental Regulations in India

\begin{tabular}{|c|c|}
\hline Title of Act, Year & Description \\
\hline $\begin{array}{l}\text { Water (Prevention and } \\
\text { Control of Pollution) Act, } 1974\end{array}$ & $\begin{array}{l}\text { - Provides for the prevention and control of water pollution and the } \\
\text { maintenance or restoration of water's purity and } \\
\text { wholesomeness. } \\
\text { Without prior consent of the State Pollution Control Board, no } \\
\text { person is permitted to establish any industry that is likely to } \\
\text { discharge sewage or trade effluent into a stream, well, sewer, or } \\
\text { on land. } \\
\text { Contravention of this provision by any person is punishable by } \\
\text { imprisonment for a prescribed minimum of } 11 / 2 \text { years. }\end{array}$ \\
\hline $\begin{array}{l}\text { Water (Prevention and } \\
\text { Control of Pollution) Cess } \\
\text { Act, } 1977\end{array}$ & $\begin{array}{l}\text { - Provides for the levy and collection of a tax on water for human } \\
\text { consumption within industries and by local authorities. } \\
\text { A rebate is available for a person or local authority that installs a } \\
\text { plant for the treatment of sewage or trade effluents. }\end{array}$ \\
\hline $\begin{array}{l}\text { Air (Prevention and Control } \\
\text { of Pollution) Act, } 1981\end{array}$ & $\begin{array}{l}\text { - No person is permitted, without the previous consent of a state } \\
\text { board, to establish or operate any industrial plant in an air } \\
\text { pollution controlled area, and where such industrial plant is } \\
\text { permitted, the emission of an air pollutant must not exceed the } \\
\text { standards promulgated by the state board. }\end{array}$ \\
\hline $\begin{array}{l}\text { Environment (Protection) Act, } \\
1986\end{array}$ & $\begin{array}{l}\text { - The central government has been empowered to take all } \\
\text { necessary measures protect and improve the quality of the } \\
\text { environment, and prevent, control, and abate environmental } \\
\text { pollution. } \\
\text { Such measures include planning and executing a nationwide } \\
\text { program prevention, control, and abatement of environmental } \\
\text { pollution; demarcate areas in which industries, operations, or } \\
\text { processes shall be carried out under certain safeguards; and } \\
\text { promulgate procedures and safeguards for handling hazardous } \\
\text { substances. }\end{array}$ \\
\hline $\begin{array}{l}\text { Public Liability (Insurance) } \\
\text { Act, } 1991\end{array}$ & $\begin{array}{l}\text { Designed to provide relief to persons affected by accidents that } \\
\text { occur while a company is engaged in handling hazardous } \\
\text { substances. } \\
\text { Every company must carry liability insurance against claims that } \\
\text { arise from such accidents. } \\
\text { - Contravention of the Act subjects not only companies, but also } \\
\text { individual supervisors, to criminal and monetary penalties. }\end{array}$ \\
\hline $\begin{array}{l}\text { Wild Life (Protection) Act, } \\
1972\end{array}$ & $\begin{array}{l}\text { - Provides protection for wild animals and birds. } \\
\text { Cas amended in } 1991 \text { to ban hunting of all species of wildlife for } \\
\text { commerce or pleasure. }\end{array}$ \\
\hline $\begin{array}{l}\text { National Environment } \\
\text { Tribunal Bill, } 1992\end{array}$ & $\begin{array}{l}\text { - If enacted, would provide for the establishment of tribunals to } \\
\text { provide relief, compensation, and restitution to victims of } \\
\text { accidents that occur as a result of handling hazardous } \\
\text { substances, and to victims of environmental damage. }\end{array}$ \\
\hline
\end{tabular}




\subsection{Industry Structure}

The Indian power sector has traditionally been almost exclusively a public sector monopoly. The structural basis for the power sector was established by the original Indian Electricity Act and the Electricity (Supply) Act of 1948 that provided for three types of utilities: the State Electricity Boards (SEBs), government-owned generating companies, and licensees. ${ }^{12}$

The SEBs generate, transmit, and distribute electricity, and control about $65 \%$ of the country's installed generating capacity. To supplement the efforts of the SEBs, the government formed the following central power utilities: National Thermal Power Corp. (NTPC), National Hydroelectric Power Corp. (NHPC), North Eastern Electric Power Corp. (NEEPCO), National Power Transmission Corp. (NPTC), and the Nuclear Power Corp. The NTPC operates coal- and gas-fired plants, and with $13 \mathrm{GWs}$ installed (which represent $13 \%$ of India's bulk power), is the country's largest single plant operator. ${ }^{13}$ Along with the NHPC, the NTPC supplies power to the grid, the retail distribution is carried out by the SEBs. The NPTC (recently renamed the Power Grid Corp.) owns all the transmission assets of the central power utilities.

The SEBs and the central government utilities account for approximately $96 \%$ of the electric power generated in India. The public utilities, however, are not as financially healthy or efficient as the private companies. Underpriced power is the culprit. In 1995-1996, the ability of the SEBs to collect only $\$ 0.821$ for every dollar it cost them to supply power was a result of the low average tariffs charged to consumers. ${ }^{14}$ Currently, five major private utilities account for the remaining 4\% of India's power supply: Bombay Suburban Electric Supply Limited, Tata Electric Companies, Ahmedabad Electricity Company, Surat Electric Company, and CESC Ltd. These five companies have a combined installed capacity of about $2.9 \mathrm{GW} .{ }^{15}$ However, continuing power shortages and the inability of SEBs and central utilities to meet rising demand compelled the Indian Ministry of Power to amend the electricity legislation in January 1991. The new legislation allows private companies to install their own capacity and distribute electricity as licensees of the SEBs.

Other players in the power sector include five regional electricity boards that oversee areas where investments of benefits are shared by multiple states, 13 municipal utilities that generate power under license from state governments, and 30 cooperatives that distribute electricity in rural areas.

\footnotetext{
${ }^{12}$ Utility Data Institute, 1996, International Directory of Electric Utilities, Eighth Edition, UDI: Washington, DC, January, p.119.

${ }^{13}$ Ibid.

${ }^{14}$ Government of India (GOI) Planning Commission, 1995, Working of SEBs, p.84.

15 Ibid., p. 120 .
} 


\subsection{Current Demand and Forecast Growth}

\subsubsection{Installed Capacity}

India has an installed generating capacity of $85 \mathrm{GW} .{ }^{16}$ More than $50 \%$ of this capacity was added between 1980 and $1990 .{ }^{17}$ This trend continued in the 1990s, when the estimated load growth was $10 \%-13 \%$ per year. Total electricity generated in 1993 was 314 billion $\mathrm{kWh} .^{18}$ Exhibit 2.4-1 shows the types of fuel used to generate power in India. Coal represents $85 \%$ of the fuel used in thermal plants, and the "Other" category consists of nuclear plants at $1.9 \%$ and renewables at $0.1 \%$.

Despite its success in adding new power capacity, the Indian power system faces several technical obstacles. As of 1990 , about $80 \%$ of the country was electrified; however, only $65 \%$ of the total installed capacity is typically available on-peak. ${ }^{19}$ The country's inability to build enough capacity to meet the rising demand has led to peak capacity shortages that range from $9 \%$ to $34 \%$ (based on regional variations). ${ }^{20}$ Larger units are also

EXHIBIT 2.4-1

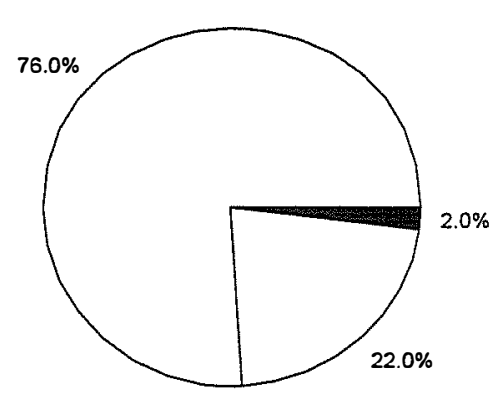

Thermal $\square$ Hydro Other of ten run at less than design capacity, which reduces overall efficiency. ${ }^{21}$ The current T\&D system exacerbates the power shortages. T\&D losses approach $20 \%$ and are attributed to several factors, including inadequate distribution systems, voltage and frequency variations, poor-quality equipment, and theft of electricity. ${ }^{22}$ Thus, even after generating at just $65 \%$ of capacity, another $20 \%$ is virtually lost because of faulty T\&D. The country's skill in addressing these factors is vital to successfully meeting future electricity demand.

\subsubsection{Fuel Sources}

Although it heavily relies on coal, India has a variety of indigenous fuels. In 1992, proven fossil fuel reserves

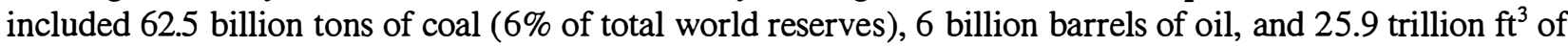
natural gas. ${ }^{23}$ Biomass resources are also abundant-in 1987, 56\% of India's total energy consumption was from biomass sources. ${ }^{24}$ Most of this consumption was for cooking and home heating. However, the local

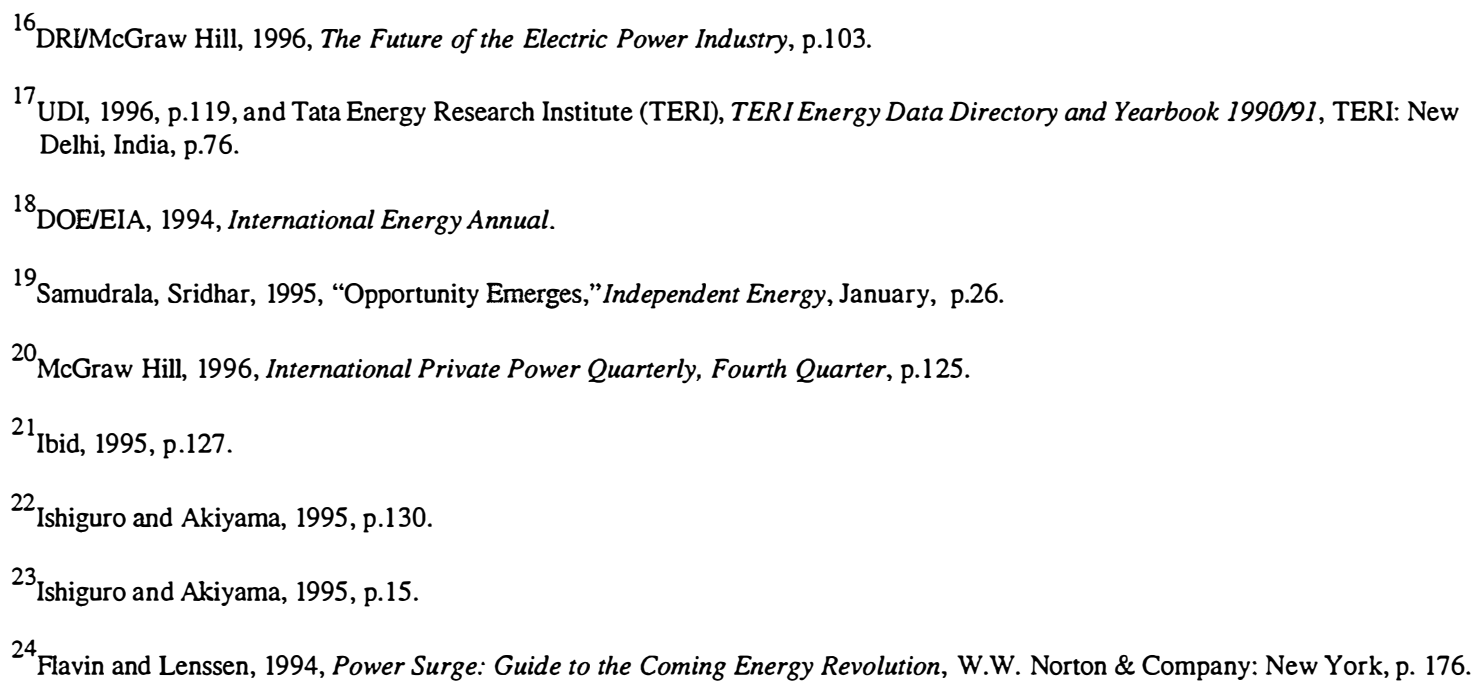


availability of the resource and the rural population's familiarity with it give biomass the potential to be widely used in small-scale power units.

The country has significant sugar, rice, wheat, maize, and industrial roundwood production, so power generated from agricultural or forestry residues is an attractive option. Bagasse-generated power is the most viable, because in 1995 India was the world's largest producer of sugar cane, with an output of 144.1 million tons. ${ }^{25}$ A recent study shows that, assuming 1 ton of cane can generate $120 \mathrm{kWh}$, Indian sugar mills can generate 2.5 $\mathrm{GW}$ of power. ${ }^{26}$ This study also states that the residues from rice, wheat, and maize production have the potential to provide more than $33 \mathrm{GW}$ of power, ${ }^{27}$ and residues from industrial roundwood can provide $3.6 \mathrm{GW}$ of power, if all the residue is used to generate electricity. Dung is also commonly used as biogas energy in rural areas, and several pilot projects that use dung in small-scale rural power plants have been undertaken.

In terms of energy crops, if 3\% of all agricultural land is devoted to energy crop production, the country could support $17 \mathrm{GW}$ of power. ${ }^{28}$ However, India's potential to develop energy crops is less promising than this figure suggests. Although more than $60 \%$ of the total area is agricultural land, food production will always have priority on land use. With a burgeoning population, the Indian government will not sacrifice the country's ability to attain food self-sufficiency for the sake of energy crop production, even if it is a cheaper or more economically beneficial energy alternative. ${ }^{29}$ In addition, a limited water supply and salinization may adversely affect the amount of land ultimately suitable for crops. But even if energy farms are not pursued with much enthusiasm, the country has a variety of organic resources that offer the fuel flexibility required for successful rural biomass power projects.

\subsubsection{Electricity Demand}

India's rapid economic growth has led to a corresponding increase in electricity demand. Current per-capita electricity consumption is about $300 \mathrm{kWh}$, compared to $10,000 \mathrm{kWh}$ in the developed world. However, with a population of more than 900 million and a growing economic base, total electricity consumption is projected to jump from $386 \mathrm{TWh}$ in 1995 to 1,245 TWh in 2020. ${ }^{30}$ This expansion is deemed essential to meeting the country's economic goals. According to S. Rajgopal, former Cabinet Secretary and Secretary of Power for the Indian government, "If India is to become a global player and achieve industrial and economic growth targets, the current per capita energy consumption needs to be raised to the world average of $2,400 \mathrm{kWh} . " 31$

To meet this rising demand, India is expected to add $305 \mathrm{GW}$ of generating capacity by 2020 , with $142 \mathrm{GW}$ needed by $2005 .^{32}$ According to information obtained from the 1996 Utility Data Institute World Electric Power Plant Database, approximately $44 \mathrm{GW}$ of power is currently planned for the country:

\footnotetext{
${ }^{25}$ USDA, 1995, Sugar \& Sweetener S\&O, vol.20, no. 2, June.

${ }^{26}$ Antares Group, Inc., 1996, Global Repowering Opportunities for Biomass Power, Appendix.

${ }^{27}$ These results assume a generation rate of $1.4,1.3$, and 1.0 tons of residue/ton of production, and heating values of $16.28,17.51$, and $17.65 \mathrm{GJ} / \mathrm{ton}$ of residue, for rice, wheat, and maize, respectively.

${ }^{28}$ Antares Group, Inc., 1996, Global Repowering Opportunities for Biomass Power, Appendix.

${ }^{29}$ Tata Energy Research Institute (TERI), personal communication, 11/20/96.

${ }^{30}$ DRU/McGraw Hill, 1996, The Future of the Electric Power Industry, p.112.

${ }^{31}$ Independent Power Quarterly, 1st Quarter 1994.

${ }^{32}$ McGraw Hill, 1996, p. 125.
} 
- $\quad 34 \mathrm{GW}$ from coal-fired units

- $\quad 5.6 \mathrm{GW}$ from natural gas-fired units

- $\quad$ 1.3 GW from oil-fired units

- $\quad 3.4 \mathrm{GW}$ from nuclear units.

In addition, the NHPC and/or the SEBs plan to develop nearly $5.8 \mathrm{GW}$ of hydroelectric power and $5 \mathrm{GW}$ of wind power. ${ }^{33}$ Recurrent power shortages, blackouts, load shedding, and the poor financial health of the SEBs hinder India's ability to meet all the future demand with its current generation capacity. The government is therefore inviting private sector investment in the power market. Through the amended Electricity Act, independent power producers are expected to add most of India's electrical capacity after the year 2000. Estimates of private power development range from 24 to $38 \mathrm{GW}$ during the next several years.

Exhibit 2.4-2 shows the sectoral breakdown of electricity consumption for FY 1995-1996. ${ }^{34}$ This sheds more light on the complications that surround the power situation in India. The industrial sector is the largest power consumer in India, mainly because its operations are more energy-intensive than their counterparts in most other countries. The agricultural sector is the second largest power consumer, but its electricity tariffs are heavily subsidized by the industrial sector and the SEBs do not want to lose this revenue. Therefore, two opposing forces are at work: efficiency improvements in industrial plants would decrease their electricity consumption, but if the SEBs lose their primary source of electricity revenue, they cannot provide agricultural subsidies, which has political implications.

Exhibit 2.4-2

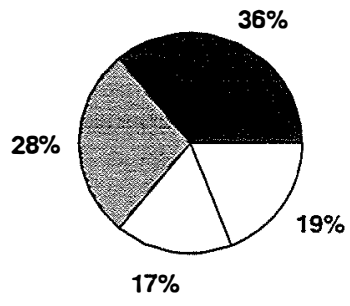

Industrial Agricultural
$\square$ Residential $\square$ Commercial, others

The current situation in the Indian paper industry is an example of some industrial inefficiencies. The country's 245 pulp and paper mills and 327 paper and board mills ${ }^{35}$ consume almost five times as much energy as do mills in industrialized countries. Energy represents approximately $25 \%$ of the manufacturing costs in the Indian paper industry. ${ }^{36}$ Specifically, the mills purchase almost $70 \%$ of their total internal energy requirement, and only $40 \%$ of them use cogeneration. ${ }^{37}$ By not using the internal biomass by-products such as black liquor and wood waste, the mills operate inefficiently. To address this issue, some state organizations are starting to work with the paper industry; the Industrial and Technical Consultancy Organization of the state of Tamil Nadu signed an agreement with Sun Paper Mill Ltd., to set up a captive 6-8-MW cogeneration plant that would use the biomass waste generated by the mill. ${ }^{38}$

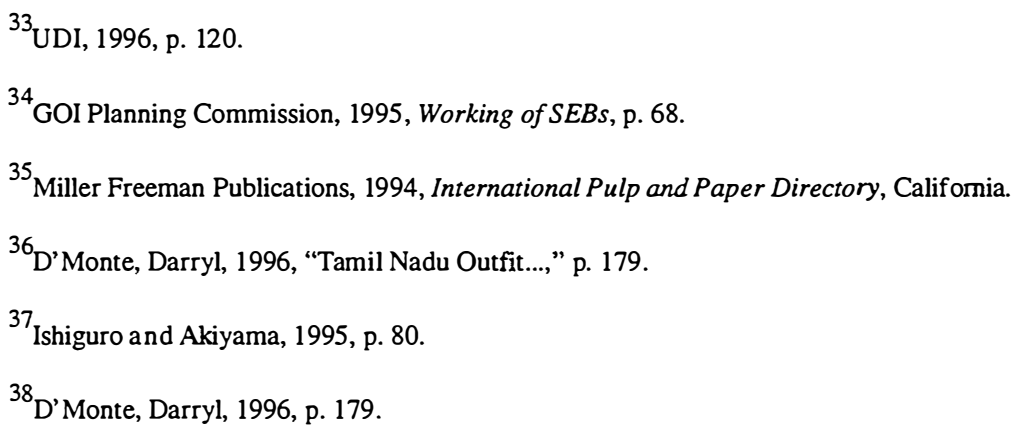


In view of these facts, Indian industrial customers appear to be direct targets for rural DG systems. Approximately $42 \%$ of India's registered small-scale industries are in rural areas. ${ }^{39}$ Proximity to raw materials has enticed many small manufacturing companies (such as cotton and jute mills) away from the urban centers. These establishments need electricity, and because the SEBs are financially strapped, power developers are looking for alternatives to selling power to the SEB. Captive power plants, such as the project at Sun Paper Mill, have been suggested as such an option. Selling power directly to one or more industrial hosts eliminates the SEB's involvement, and avoids power shortages and the poor quality of grid supply.

However, captive plants still need approval from the SEB, so the SEB is faced with a dilemma. It knows it cannot provide reliable, reasonably priced power to industry, which can be provided by the captive plants, but it also needs the revenue from these customers. By granting approval for these plants, the SEBs would help industry but would lose a major source of financing, hence the dilemma. There may be, however, a way to solve this problem. The SEBs can grant approval, if the captive plants sell their excess power back to the SEBs for less than the SEBs cost to deliver electricity to its customers. Thus, the industrial host receives reliable power and the SEB can service a portion of its electricity demand at a lower cost. The Indian government recognized this potential and recently amended its private sector investment policies to allow captive plants and SEBs to set up such relationships. ${ }^{40}$

${ }^{39}$ GOI, Office of the Economic Adviser, 1995, Handbook of Industrial Policy and Statistics 1995, p. 215.

${ }^{40}$ GOI, Ministry of Power, 1994, India's Electricity Sector - Widening the Scope for private Participation.. 


\subsection{General Benefits of Electricity}

Benefits associated with power development are of interest to national policy makers and planners who are seeking to provide electricity equitably across India. A basic set of benefits are accrued just by providing constant, reliable power to areas that either never had it or had unreliable power. These are discussed in two contexts: macro-level socioeconomic benefits and benefits in the form of reduced agricultural subsidies.

\subsection{Macro-Level Socioeconomic Benefits}

Inf rastructure raises productivity, improves living standards, and helps modemize and diversify production in an economy. In most developing countries, power has been given primary importance in overall infrastructure plans. The World Bank's lending to power projects increased from $\$ 72$ million in 1950 to $\$ 2.6$ billion in $1993 .{ }^{41}$ Outlays for energy also comprised the largest percentage of official development assistance for infrastructure (based on OECD's calculations) in 1991. ${ }^{42}$ Although linkages between power and economic growth have not been explicitly proven, ${ }^{43}$ several socioeconomic benefits do accrue when reliable power is introduced. These benefits usually stem from rural electrification (RE) programs.

Many developing countries' national plans have included RE as an important part of rural economic development strategies. Government officials believe that RE can help rectify some of the large economic imbalances between rich urban and poor rural areas in their countries. The Indian government is one example. RE was introduced in the country's first 5-year plan of 1951-1956, and was initially envisioned to provide electricity as a social amenity. ${ }^{44}$ It was first confined to a few states, but was eventually extended to all states. The program gained importance during the drought in the mid-60s, when large-scale lift irrigation was needed to save subsistence crops.

During FY 1995, the percentage of total power sector outlay given to states for RE programs ranged from $0.25 \%$ for the Delhi SEB, to $14.6 \%$ for the Meghalaya SEB (non-RE generation, renovation, and modernization, and T\&D comprise the remainder of the total outlay to states). ${ }^{45}$ In terms of overall percentages, India's RE program implementation has been fairly successful. By $1995,85 \%$ of the villages were served by grid electricity and 11 of 25 states had electrified $100 \%$ of their rural areas. ${ }^{46}$ However, these figures are misleading because, according to the government's current definition, a village is considered electrified if one or more households have this service. ${ }^{47} \mathrm{RE}$, therefore, can still play a significant role.

$\mathrm{RE}$ is often perceived as a catalyst for economic development. Consumers depend on reliable electricity for their daily activities. 'It helps make business and industry more productive and profitable; India's original focus on energizing water pumpsets increased agricultural productivity. In fact, power shortages and unreliability have been determined to adversely affect industrial production. Some studies have tried to correlate gross domestic product (GDP) and electricity sales; in 1983-1984, the effect of power shortages on Indian industry

\footnotetext{
${ }^{41}$ World Bank, 1994, World Development Report 1994 -- Infrastructure for Development, p.149.

${ }^{42}$ World Bank, 1994, p.149.

${ }^{43}$ Schramm, Gunter, 1993, Rural Electrification in LDCs as a Tool for Economic Development: Facts and Fiction, p.4.

${ }^{44}$ Govemment of India (GOI), 8th Five Year Plan, p. 195.

${ }^{45}$ GOI Planning Commission, 1995, Working of State Electricity Boards and Electricity Departments, p. 27.

${ }^{46}$ TERI, 1995/96,TEDDY, p. 72.

${ }^{47}$ GOI, 8th Five Year Plan, p. 195.
} 
was calculated to yield a $1.5 \%$ loss in GDP. ${ }^{48}$ These production losses vary by industry and region-for example, loss in the iron and steel industry was about $43 \%$ in the southern region but only $3.5 \%$ in the western region. ${ }^{49}$ If averaged across all large industries in a region, industrial production losses ranged from $1.5 \%$ in the western region to $13 \%$ in the eastern region..$^{50}$ Furthermore, these figures are underestimated because they exclude the value of foregone services associated with residential and commercial outages, and they exclude the income that is lost in future periods as a result of current losses.

There can be direct economic benefits in providing power to an area. New jobs are associated with supplying fuel to the plant, transporting the fuel, and constructing and regularly maintaining the plant. However, calculating the net gain in employment for the service area is important because even though the new plant may create jobs, it may also unemploy or underemploy other people. This could happen in the case of an advanced biomass-based distributed system that replaces a coal-fired plant if some workers at the coal-fired plant are not able to transfer their skills. There are also broader economic impacts to reliable power, often referred to as the secondary and induced effects of a specific economic activity. This "multiplier" effect can create jobs in ancillary industries such as equipment manufacturers and other service industries.

A recent study on India concluded that a biomass-based power plant can support a rural industrial complex and add value to the agricultural economy. ${ }^{51}$ The researchers studied a rural industrial complex planned for a population of 20,000 to 25,000 . It contained a biogas power plant (supplying $145 \mathrm{~m}^{3} /$ day of fuel gas), which would support a dairy, flour mill, fruit and vegetable processing unit, and a milk processing unit. The researchers assumed that the complex would benefit from the backward and forward linkages, where the industrial units would supply fuel to the power plant, and it, in tum, would supply power to them. They calculated that about 60 jobs would be created: 45 in the dairy and three to five jobs in each of the other four establishments, including the power plant. The researchers point out that such a complex would survive only where the raw materials were readily available, so not every rural region in India can implement such a complex. However, with a rural population of 675 million (900 million total population with $75 \%$ in rural areas), and a diverse agricultural economy, the potential to support similar systems seems significant, and would give biomassfueled power an integral role.

Reliable power offers several additional socioeconomic benefits. It may stem rural-to-urban migration, and reduce the strain on already overburdened urban infrastructure and public services. There are also quality-oflife improvements and productivity increases. In most developing countries, women are responsible for household activities. Regular electricity can make their lives easier by allowing for flexibility in rescheduling chores and food preparation. Quality of life is improved through the increase in leisure time, because more productive domestic and work environments foster more free time.

How directly electrification relates to economic development is unclear, because although electrification does improve the quality of life, it cannot do so in a vacuum. If household incomes are not simultaneously raised, electrification may actually widen the gap between the "haves" and the "have-nots." ${ }^{\text {"If }}$ If left at the same income level, the very poor often cannot afford the electricity or the end-use equipment (e.g., appliances) associated with it. Therefore, although it is widely used and accepted, RE alone does not raise living standards but is an integral part of overall economic development.

\footnotetext{
${ }^{48}$ Jones, et.al, 1988, The Impacts of Inadequate Electricity Supply in Developing Countries, p. 17.

${ }^{49}$ USAID, 1988, Power Shortages in Developing Countries: Magnitude, Impacts, Solutions, and the Role of the Private Sector, p. 18.

${ }^{50}$ USAID, 1988, p. 18.

${ }^{51}$ Vijay, V.K., et al., 1996, “A Case for Biogas Energy Application for Rural Industries in India,” pp. 993-996.

52 Jones, et al., 1988, p. 36.
} 


\subsubsection{Summary}

General benefits associated with reliable power include:

- $\mathrm{RE}$ and economic development

- primary and secondary job creation (e.g., at power plant, in equipment manufacturing)

- development of ancillary industries

- improved productivity

- Stemming rural-to-urban migration

- Improved quality of life.

\subsection{Reduced Subsidies}

Electric power tariffs constitute a practical and efficient way to raise public revenues, and subsidies help provide basic energy needs to the low-income groups. Subsidies, however, are inefficient because the price of electricity does not reflect its true cost. This is true in India, where subsidies have actually hurt the SEBs and, in tum, hindered the advancement of the electric power sector. A reduction in subsidies, therefore, benefits the whole country because it strengthens the states' economies and the power industry. Herein lies another role for DG systems. If RE is successful in broadening the area's economy and helping raise its standard of living, electricity subsidies for that area become less necessary because the people can better afford to pay for power. As a result, the SEB can reduce its subsidies to that area and have a corresponding decrease in revenue loss. Nationwide benefits would then accumulate as this effort is duplicated from state to state.

In an attempt to promote development for rural areas, the Indian SEBs have historically subsidized the agricultural sector (see Exhibit 3.2-1). This is because India's economy is mainly based on agriculture, and power subsidies are a way to maintain stability in the rural economy. Unfortunately, this has led them to a cycle of poor financial health and a deteriorating performance record. The SEBs have not been able to raise enough revenue to honor current financial obligations, maintain facilities, or expand infrastructure to meet rising demand. Furthermore, India's Electricity Supply Act specified a statutory rate of retum of 3\% for the SEBs. To achieve this rate, SEBs would have to raise their electricity tariffs an average of $24 \% .^{53}$

To illustrate these points, in 1994-1995: ${ }^{54}$

- The agricultural sector consumed $29.1 \%$ of total electricity sold in the country

- Revenue from the agricultural sector comprised only $4.8 \%$ of total sales revenue to the SEBs

- The SEBs received a rate of return of $-10.5 \%$ in $1985-1986$

- Their rate of return declined to $-14.2 \%$ in $1991-1992$.

\footnotetext{
${ }^{53}$ TERI, 1995/96, TEDDY, p. 141.

${ }^{54}$ GOI Planning Commission, 1995, pp.69-72.
} 
The effective subsidy is the amount actually lost by the SEB because it sells at less than average cost to a sector. In 1992-1993, the effective subsidy to agricultural consumers was $\$ 2.06$ billion, and it jumped to $\$ 2.9$ billion in 1994-1995 (an exchange rate of Rs.35 to $\$ 1$ U.S. was used). ${ }^{55}$ To put this in context, in 19941995 the average electricity tariff (across all customers) was more than six times the average agricultural tariff. ${ }^{56}$ Within these amounts, cross-subsidization from the commercial and industrial sectors to the agricultural sector comprised $22.9 \%$ of the total subsidy in 1990-91, and $44.9 \%$ of the total subsidy in 1994-1995. ${ }^{57}$

\section{Exhibit 3.2-1 Average Electricity Tariff Charged by State Electricity Boards (Paise* per kWh)}

\begin{tabular}{|l|r|r|r|r|r|}
\hline $\begin{array}{l}\text { State Electricity } \\
\text { Boards }\end{array}$ & Domestic & Commercial & Industrial & $\begin{array}{r}\text { Public } \\
\text { Lighting }\end{array}$ & Agricultural \\
\hline \hline Andhra Pradesh & 75.25 & 145.00 & 135.89 & 66.62 & 14.52 \\
\hline Assam & 80.00 & 169.75 & 141.09 & 150.00 & 76.00 \\
\hline Bihar & 95.42 & 109.92 & 156.00 & 100.00 & 41.33 \\
\hline Goa & 78.00 & 131.00 & 125.09 & 80.00 & 84.00 \\
\hline Gujarat & 76.09 & 171.25 & 148.09 & 5.07 & 16.00 \\
\hline Haryana & 76.75 & 149.00 & 162.18 & 109.00 & 21.00 \\
\hline Himachal Pradesh & 54.00 & 120.00 & 89.60 & 60.00 & 33.00 \\
\hline Karnataka & 78.68 & 192.48 & 115.68 & 76.44 & 6.53 \\
\hline Kerala & 48.66 & 78.00 & 56.09 & 24.87 & 22.00 \\
\hline Madhya Pradesh & 30.57 & 125.27 & 147.79 & 45.29 & 15.87 \\
\hline Maharashtra & 82.98 & 182.99 & 154.00 & 90.00 & 15.00 \\
\hline Meghalaya & 49.62 & 94.20 & 85.97 & 86.35 & 27.78 \\
\hline Orissa & 48.87 & 87.29 & 72.46 & 48.95 & 34.00 \\
\hline Punjab & 87.26 & 136.30 & 99.46 & 123.55 & 8.15 \\
\hline Rajasthan & 68.05 & 115.98 & 120.07 & 77.00 & 36.55 \\
\hline Tamil Nadu & 69.86 & 181.26 & 162.79 & 104.97 & exempted \\
\hline Uttar Pradesh & 97.07 & 155.99 & 179.09 & 135.00 & 35.68 \\
\hline West Bengal & 72.77 & 115.05 & 123.21 & 63.60 & 32.55 \\
\hline DESU & 65.50 & 183.03 & 178.91 & 125.00 & 20.00 \\
\hline
\end{tabular}

*Note: 100 paise $=1$ Rupee (Rs); Rs $34.855=\$ 1$ U.S. (June 1996)

Source: Basic Statistics Relating to the Indian Economy States, CMIE, September 1993.

\footnotetext{
${ }^{55}$ GOI Planning Commission, 1995, p. 125.

${ }^{56}$ GOI Planning Commission, 1995, pp. 118-120.

${ }^{57}$ GOI Planning Commission, 1995, p. 7.
} 
Furthermore, some states have only partly compensated their SEBs for these subsidies, and some states do not compensate them at all. In addition to the $44.9 \%$ from cross-subsidies in 1994-1995, state government compensation amounted to only $14 \%$ of the effective subsidies that SEBs had to bear (14\% included subsidies for the agricultural and domestic sectors).$^{58}$ Although cross-subsidies and state government assistance are ways for SEBs to counteract the effect of the subsidies, last year the SEBs still had to absorb $55.1 \%$ of the subsidy cost. If even $1 \%$ of the agricultural subsidies were eliminated, the SEBs would save $\$ 29$ million (1\% of $\$ 2.9$ billion).

There are political and social reasons for maintaining subsidies, but if the SEB is unable to collect enough revenue to offset its costs, it has to take money from another source to supplement the deficiency. This affects the state's economy because it may force the state to institute higher income taxes, sales taxes, or fees, which can put an undue burden on consumers and on the overall economy. This is an even bigger problem in developing countries such as India because they do not have sophisticated enforcement mechanisms, and they of ten have large "underground" economies. As a result, tax rates and fees may increase, but in reality, the states may not be able to collect the money due. This spiraling effect is the reason SEBs are reluctant to give up their primary revenue source and approve industrial captive plants, unless they can benefit as well.

The SEBs' poor financial situation also directly affects future power development. They are expected to have losses of $\$ 2.2$ billion in 1996. To compensate, many private power developers are seeking "counter guarantees" from the central government for large projects. ${ }^{59}$ However, this time-consuming. In addition, conservation objectives usually run counter to subsidy effects. Inexpensive power provides no incentive to conserve resources or reduce electricity demand. Subsidies also distort the choices between various energy supply alternatives because they are usually not subsidized or are subsidized to a lesser degree. If they are a part of a successful RE plan, biomass-based DG systems can help reduce the need for agricultural subsidies. The SEBs can then collect more revenue and lower their financial losses, which would strengthen them and the whole power sector in the process.

\subsubsection{Summary}

Reducing agricultural subsidies will generate more revenue for the SEBs, which will allow them to:

- Build a pricing structure that better matches the true cost of production

- Meet financial obligations

- Maintain facilities

- Meet rising demand

- Obtain a profitable rate of return

- Attract private power developers without the need for counter guarantees

- Save $\$ 29$ million if only $1 \%$ of the current effective subsidy is eliminated.

${ }^{58}$ GOI Planning Commission, 1995, p. 85.

59 "One Watt at a Time," 1996, The Economist, p. 65. 


\subsection{Benefits of DG Technology Using Biomass}

Benefits of biomass-based DG systems accrue by changing from a remote, centralized service that uses imported and indigenous fuels, to building a localized system based on modular technology that uses only indigenous fuels. Decentralized power that uses biomass can avoid T\&D losses, offer a participatory project development process, and increase rural employment based on an indigenous resource. The modularity associated with DG systems offers planning and financing benefits to the project developer.

\subsection{Decentralized Power}

The benefits of DG are hotly debated. Most discussions focus on avoided costs such as the savings accrued through reduced line losses and capital savings on new lines and substations. Additionally, avoided costs may include estimates of productivity losses that result from unreliability in the central power supply or financing benefits associated with the construction of several small power facilities rather than one large plant.

\subsubsection{Transmission and Distribution Losses}

T\&D losses in India averaged $18.9 \%$ in 1995-1996 (see Exhibit 4.1-1). These losses are due to a lack of adequate investment in T\&D systems, too many transformation stages (which result in high transformer losses), improper load distribution, and extensive RE ${ }^{60}$ To address this issue, a governmental committee recommended that $50 \%$ of the total outlay to the power sector should be earmarked for $\mathrm{T} \& \mathrm{D}$ facilities, with a high priority given to the construction of high-tension transmission lines of $400 \mathrm{kV}$ and $220 \mathrm{kV}$. $^{61}$

There is also a rising share of $11 \mathrm{kV}$ distribution lines-the proportion of low-tension lines increased from $4.2 \%$ in $1965-1966$ to $15 \%$ in $1992-1993 .{ }^{62}$ This is attributed to providing electricity to remote areas and the increased emphasis on RE. However, the T\&D lines are not equipped to service the increasing number of distribution lines, so many line losses are due to the extension into rural areas. In fact, there is some evidence that as many as $50 \%$ of the T\&D line losses are associated with the RE network. ${ }^{63}$ Because this network is predominantly served by central plants via grid extension, DG systems can help curtail some of these losses associated with RE efforts. Estimates of T\&D costs are discussed in Section 7.5.

\subsubsection{Public Participation}

The next set of benefits associated with decentralized power centers around public participation. By localizing a previously removed service such as central grid electricity, the DG systems can be designed to meet local needs and cultures, and siting will more likely fit with local values. Thus, communities will have more say in what affects their immediate surroundings and will be given more control because they are helping meet the rise in electricity demand. This helps alleviate local political discontent by helping establish a stronger link between local areas and state government. Biomass-based DG systems can also promote local skill acquisition, energy self-sufficiency, and the development of rural cooperatives. Distributed systems can also reduce the displacement of human settlements associated with large power projects.

\footnotetext{
60 TERI, 1996, TEDDY 1995/96, p. 71.

${ }^{61}$ TERI, 1996, TEDDY 1995/96, p. 71.

${ }^{62}$ TERI, 1996, TEDDY 1995/96, p. 71.

${ }^{63}$ GOI, 8th Five Year Plan, p. 195.
} 
Exhibit 4.1-1. T\&D Losses as a Percentage of Availability (1995/96)

\begin{tabular}{|c|c|}
\hline State Electricity Boards & Percent \\
\hline Andhra Pradesh & 18.0 \\
\hline Assam & 20.5 \\
\hline Bihar & 19.0 \\
\hline Delhi (DESU) & 20.0 \\
\hline Gujarat & 20.0 \\
\hline Haryana & 22.5 \\
\hline Himachal Pradesh & 16.6 \\
\hline Jammu \& Kashmir & 41.9 \\
\hline Karnataka & 18.0 \\
\hline Kerala & 19.0 \\
\hline Madhya Pradesh & 18.5 \\
\hline Maharashtra & 15.0 \\
\hline Meghalaya & 13.6 \\
\hline Orissa & 22.0 \\
\hline Punjab & 18.2 \\
\hline Rajasthan & 21.5 \\
\hline Tamil Nadu & 16.5 \\
\hline Uttar Pradesh & 21.0 \\
\hline West Bengal & 20.0 \\
\hline \multicolumn{2}{|l|}{ Electricity Departments } \\
\hline Arunachal Pradesh & 29.0 \\
\hline Goa & 19.3 \\
\hline Manipur & 22.0 \\
\hline Mizoram & 26.0 \\
\hline Nagaland & 30.1 \\
\hline Pondicherry & 14.5 \\
\hline Sikkim & 20.1 \\
\hline Tripura & 29.0 \\
\hline AVERAGE & 18.9 \\
\hline
\end{tabular}

Source: GOI Planning Commission, 1995, p. 63. 


\subsubsection{Use of Biomass Fuel}

Using biomass as the fuel for the DG systems also offers employment benefits. An example was the rural industrial complex discussed in section 3.1, where four to five jobs were provided at the power plant. There are also labor benefits on the fuel supply side. When instituted in a rural area, these systems use an agriculturalbased fuel in an agricultural economy, so the people in the region are already familiar with the resource. This can create new harvesting and residue handling jobs. Even if the residues are already used for compost or fertilizer, the DG systems can tum these by-products into a commodity by creating another market for them (this would happen only if the cost of the replacement fertilizer were less than the profit received from the power plant for the residue). Farmers then have incentive to diversify their crop base, which can diversify the rural economy.

There are also environmental benefits in the form of reduced air emissions of using biomass fuel. The environmental impacts for each DG technology are discussed later in this report.

\subsubsection{Summary}

Benefits associated with decentralized power that uses biomass include:

- Avoided T\&D losses

- Public participation

- Job creation and diversified agricultural economy through use of biomass fuel

- Rural familiarity with resource

- Environmental benefits of using biomass fuel (see Section 7.0).

\subsection{Modularity}

Modularity can benefit the power project developer and the country as a whole. It allows a large number of units to be placed relatively quickly to meet increases in power demand. The developer can add new units as needed, then move them in case a site is not approved. These systems have location flexibility, which gives them a higher salvage value; if a system is not feasible for one area, it can be moved to a better location. They also have partial availability - the whole system does not have to shut down if one part is nonoperational. Mobility allows for greater planning flexibility. It may provide shorter lead times for generation, $T \& D$ than nonmodular plants.

This early availability means that the modular plant can bring in revenues earlier than nonmodular plants; i.e., while the nonmodular plant is still under construction. For example, assume a 50-MW modular unit has a 6month lead time (i.e., a 500-MW plant takes 5 years to complete) and a 500-MW unit has a 5-year lead time. If each unit has a 20-year life, the modular unit can start to earn revenue 6 months after the start of construction; the nonmodular plant produces no revenue until the fifth year. ${ }^{64}$ Furthermore, if a 500-MW plant has revenues of $\$ 500$ million every 6 months and the discount rate is $10 \%$, the present value of the modular plant

${ }^{64}$ Hoff and Herig, Managing Risk Using Renewable Energy Technologies, p.21. 
is $\$ 710$ million versus $\$ 540$ million for the nonmodular plant. ${ }^{65}$ Therefore, through the time value of money advantage, modular systems provide this unique benefit.

International power project development faces a higher level of uncertainty and risk than are associated with domestic power development. Issues such as the country's economic and political stability, foreign investment policy, and financing difficulties can prolong project development. By instituting DG systems in a country such as India, international power developers have added advantage in approaching some of these hurdles. The shorter lead times associated with modular systems reduce project risk because cost overruns tend to be smaller and less revenue is lost because of plant delays. ${ }^{66}$ Furthermore, developers only have to finance only one segment of a DG system at a time, so they incur fewer initial costs and need less working capital, and they can stop the project without facing a total loss. ${ }^{67}$

On the manufacturing side, modularity can foster new economic activity. DG system technologies coupled with India's skilled, inexpensive workforce can help move the country beyond import substitution. By manufacturing these units inexpensively in-country, new jobs can be created in India and, in the longer term, the units can be exported. Production economies associated with DG systems are addressed in section 7.0.

\subsubsection{Summary}

Benefits associated with modularity include:

- Location and planning flexibility

- Early availability

- Less up-front working capital needed, as each segment can be financed one at a time

- Ability to be manufactured inexpensively in-country.

\footnotetext{
${ }^{65}$ Hoff and Herig, p. 22.

${ }^{66}$ Hoff and Herig, p. 26.

${ }^{67}$ Hoff and Herig, p. 26.
} 


\subsection{Benefits of Central Grid Coal-Fired Power Plant}

India's power development process has traditionally centered around large coal-fired plants. Many factors influence the decision to build a power plant, but this section focuses on two reasons for India's approach: the potential benefits of economies of scale and the benefit of using coal.

\subsection{Economies of Scale}

Economies of scale provide a greater than proportionate return for a proportionate change in all inputs; if inputs in an industrial process are doubled, outputs are more than doubled. As more product is made or service becomes available, the per-unit cost decreases. Conversely, inputs and outputs in a situation with constant retums to scale have a one-to-one relationship. Scale economies are attributed to industrial processes, infrastructure services such as power and water, and regional economic development. Industrial and economic development are positively correlated with the rise of cities. In explaining rates of urbanization, regional economists state that economic activities agglomerate at certain locations, mainly because of the benefits of economies of scale. Urbanization draws the major economic players to a concentrated area.

India is no exception to this trend. Its rapid urbanization justified building large-scale power plants close to cities to efficiently serve their growing customer bases. With a large-scale plant, more electricity consumers can be served from a central source. Multiplier effects also increase as the size of the establishment increases. As economies agglomerate, labor moves into the area to take advantage of more jobs. The number of ancillary businesses then rises as the number of potential customers increases. One early study concluded that the capital cost for each kilowatt of power produced declines as demand increases: assuming a subtransmission line length of $4 \mathrm{~km}$, the capital cost (in 1972 dollars) of electricity supplied from a $20-\mathrm{kW}$ grid plant was $\$ 543$ per customer versus $\$ 400$ per customer from a $50-\mathrm{kW}$ grid plant. ${ }^{68}$ The authors said that in addition to the ability to serve more customers from the same location, the cost reduction was due to technical economies of scale, for which the per-unit setup, storage, and initial costs (e.g., design costs) decreased as the plant size increased. Furthermore, lower per-unit costs are realized in an area that has a concentrated demand for power, because siting and permitting are needed once (instead of many times) for distributed systems.

However, the benefits of scale economies specifically related to power plants have been questioned. Some have argued that economies of scale are not realized to this extent and do not significantly reduce the cost of electricity to the customer. Refer to section 7.2 for a more detailed explanation.

\subsubsection{Summary}

Economies of scale provide the following benefits:

- Support urbanization trends

- Efficiently serve a concentrated set of customers

- Attract ancillary industries to the area

- For power plants, offer technical economies of scale (e.g., decreased per-unit setup and siting charges)

${ }^{68}$ Turvey and Anderson, 1977, Electricity Economics, p. 155. 


\subsection{Coal in India}

The coal mining industry in India was privately owned until 1973, when all coal mines were transferred to national ownership. With an annual production of more than 200 million tons, India ranks third in coal production (after China and the United States). ${ }^{69}$ Coal India Limited is the second largest employer in the world. It has about 646,000 employees, and contributes more than $90 \%$ of the coal produced in the nation. ${ }^{70}$ Coal is predominantly used by power utilities, which account for more than $60 \%$ of India's total consumption. ${ }^{71}$

Most Indian coal, however, is not very high quality. Large portions of the reserves are low-quality noncoking coals; typical Indian coal has an energy content between 6,000 and 8,000 Btu/lb, an ash content of $26 \%$ to $32 \%$, and a sulfur content between $0.2 \%$ and $0.5 \%$ by weight. ${ }^{72}$ Despite high production levels and low quality, coal demand exceeds supply. Transportation problems exacerbate the shortages. Sixty-seven percent of all coal produced in 1991 was transported by rail. The railway system, however, is strained and operating at capacity saturation levels. ${ }^{73}$ Upgrading this system will require large capital investments. Nevertheless, the country's substantial reserves, the industry's contribution to the economy, and a government-set minemouth price allow coal to dominate the power market.

The central government fixes the pithead price of coal as directed by the 1945 Colliery Control Order. ${ }^{74}$ Price revisions are based on the recommendations of the Bureau of Industrial Costs and Prices, which seeks to compensate coal companies for any increase in the cost of coal production. According to these recommendations, the pithead price of coal should be based on the average costs of production and some return on capital, but in many cases, coal prices are fixed below the average cost of production. However, contrary to popular belief, coal used by the power and industrial sectors is not subsidized. ${ }^{75}$

The pithead price is set by the government, but the delivered price of coal varies based on transportation costs. Each power station negotiates a delivered rate with its coal suppliers. This geographic sensitivity allows plants located close to coal reserves (e.g., in the eastern states of Orissa and West Bengal) to pay less for the same coal than plants located elsewhere. In response to this, there has been interest in developing pithead power stations, which locate the plant at the coal mine. This takes advantage of the high-quality reserves and avoids the transportation costs.

Abundant reserves and the industry's significant contribution to the country's employment will maintain coal's dominant position in the Indian power sector. The residential sector is subsidized for using coal, but because it comprises such a small percentage of the total consumption, its subsidies do not greatly affect the overall health of India's coal economy. In summary, a power plant fired by coal offers the benefits of historical presence, synergism with an extensive transportation infrastructure, and a substantial national employment impact.

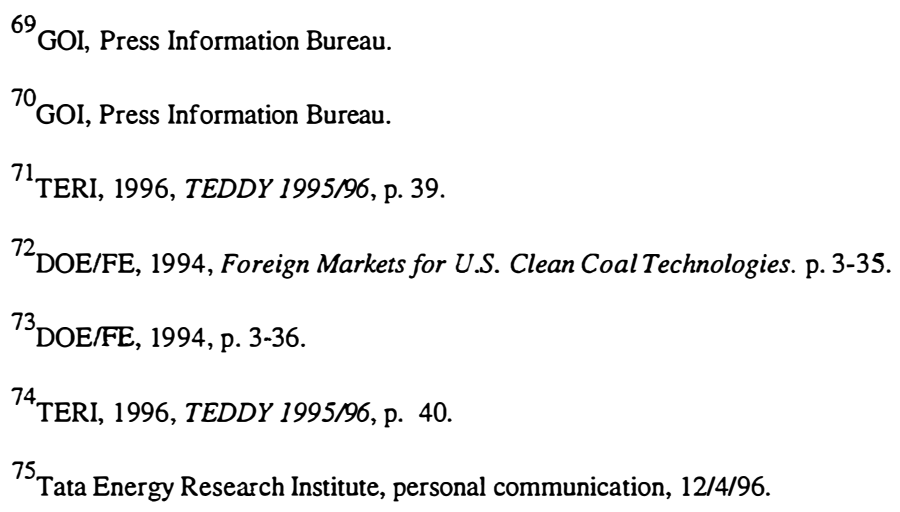




\subsubsection{Summary}

Benefits of using coal in India include:

- Abundant reserves

- The coal industry employs a significant percentage of the working population

- Uses a well-established transportation infrastructure

- Pithead price of coal is fixed by the government.

\subsection{Summary of Benefits}

Regardless of how it is supplied, rural areas of India will benefit from the introduction of reliable power. The potential macro-level socioeconomic benefits and reduced subsidies are reasons enough to forge ahead with rural power development. Biomass-based DG systems provide an added set of economic, social, and environmental benefits that other options cannot claim, but we cannot ignore the dominance of central-grid coal plants in India's electricity mix. Thus, the remainder of the report focuses on the comparative COE analysis of DG systems versus central grid coal-fired plants. 


\title{
6.0 Biomass Distributed Generation Technologies Description
}

\author{
Exhibit 6.0-2. Summary of Economic Size Ranges for Each Technology
}

\begin{tabular}{|l|l|}
\hline \multicolumn{1}{|c|}{ DG Technology } & \multicolumn{1}{c|}{ Size } \\
\hline Stirling engine & Greater than $1 \mathrm{~kW}$, less than $100 \mathrm{~kW}$ \\
\hline Direct-fired combustion turbine & Greater than $5 \mathrm{MW}$, less than $25 \mathrm{MW}$ \\
\hline Fuel cell* & Greater than $25 \mathrm{~kW}$, into the MW size \\
\hline BIGCC & Between 20 and $80 \mathrm{MW}$ \\
\hline \multicolumn{2}{|c|}{${ }^{*}$ Smaller fuel cells may be introduced as part of the transportation market }
\end{tabular}

The technologies examined in this report are Stirling engines, direct-fired combustion turbines, fuel cells, and BIGCCs. Several factors must be considered when determining which technologies are best suited for a particular biomass DG technology, including the amount of power required to meet the needs of the end-use market, the load characteristics of the demand, the availability of feedstock, emission requirements, and process steam requirements. These are in addition to social and economic concerns.

The following technologies represent only a few of the innovative biomass power DG configurations being developed. Other possibilities, including diesel engines using producer gas, have already been field tested. However, this particular technology (and many others) have low cycle efficiencies or other complications (in this example $15 \%-35 \%$ of the total fuel requirement must still met by petroleum diesel fuel) that may inhibit their potential for expanding into widespread commercial use.

An issue of ultimate importance with respect to biomass power in India is the availability of biomass resources for use as fuel for these technologies. In this respect, the smaller technologies that can be supported by small amounts of waste residues will have a considerable advantage in the rural sector. Competing uses for land in the agricultural community will probably not allow for significant acreage to be dedicated to energy crop production, and in general, there is not a lot of abundant, well centralized waste material available for power production. In fact, residues are likely to be used for home heating or cooking.

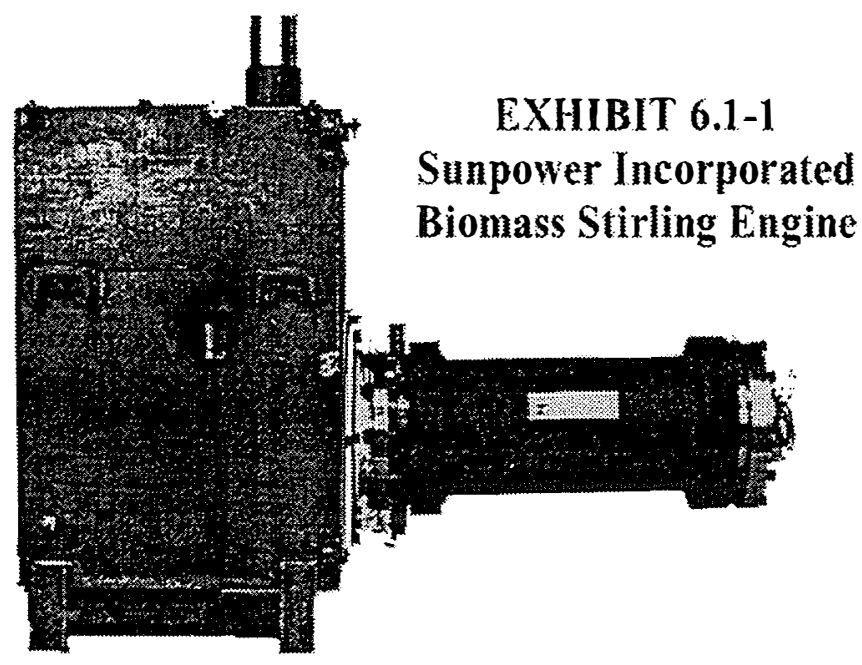

However, having considered these issues, we can make some initial forecasts about which biomass technologies will affect the future power generation market, and how well they may fill the role as DG power systems. The results of this analysis will provide data (based on calculated COEs) on how well these technologies may compete against coal-fired central grid electricity. A brief overview of each of the four technologies selected is provided as part of this section, and more detailed discussions relevant to operating and capital cost issues are reserved for Section 7. 


\section{STM BioStirling System}

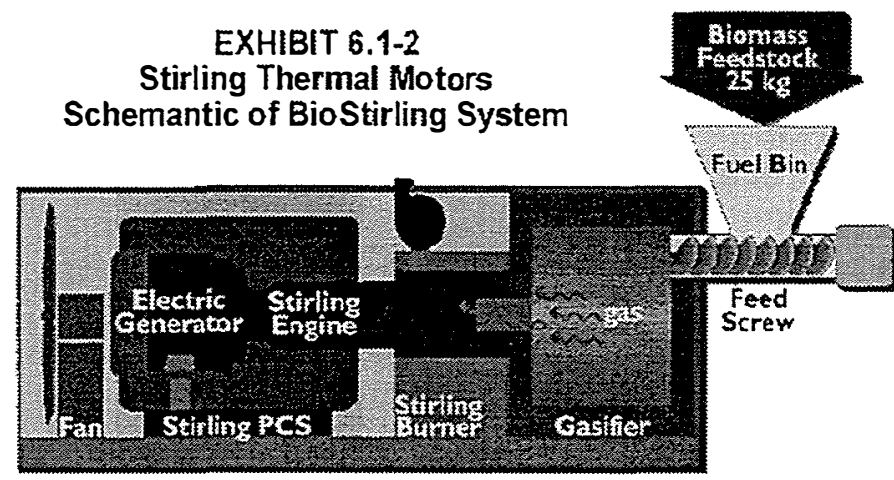

Figure 4

\subsection{Stirling Engines via Biomass Gasification}

Stirling engines are under development for various applications and in many sizes. Currently two types of engines, kinematic and free-piston, are being investigated. Both types are applicable for small (less than $100 \mathrm{~kW}$ ) DG applications, and they share a number of other key characteristics. In general, Stirling engines enjoy good efficiencies (even at part loads) and a high degree of fuel flexibility. The low environmental impacts of these engines including noise, exhaust emissions, and heat rejection, improve siting flexibility, and may make these systems suitable for a variety of DG applications. Initially, these systems may find their niche competing with gasoline- and diesel-fired generation.

These characteristics may make Stirling engines ideal for powering small villages or groups of villages that do not require extensive $T \& D$ inf rastructure. If manufactured inexpensively enough, they may also provide an economic means of providing grid stabilization for villages that already have power. Refer to Figures 6.1-1 and 6.1.2 for examples of biomass-powered Stirling engines.

\subsection{Direct-Fired Combustion Turbines}

Direct-fired combustion turbine systems, such as the ones being tested by BIOTEN at Red Boiling Springs, Tennessee, attempt to join the operational efficiency and reliability of combustion turbines with biomass-derived fuels without a separate gasification step. Initial development of directfired combustion turbines have been plagued by technical problems that include turbine blade fouling, fuel feeding and drying, high oxides of nitrogen $\left(\mathrm{NO}_{\mathrm{X}}\right)$ emissions, system availability, and concerns about overall system safety. Of perhaps greatest concern is the limited number of acceptable biomass fuels. Currently, many research data $\begin{array}{llllllllll} & \mathrm{v} & \mathrm{a} & \mathrm{i} & \mathrm{l} & \mathrm{a} & \mathrm{b} & \mathrm{l} & \mathrm{e}\end{array}$ on these systems are based on tests performed using sawdust, which because of its small particle size and material properties, is an ideal biomass material to use in this application. Future tests of these systems use a wider array of biomass materials will ultimately determine their share of the biomass power market. However, the engineers at BIOTEN have managed to overcome many of these obstacles in a manner sufficient to allow for commercial-scale demonstration of the technology. In some cases, this has meant comromising efficiency, but the facility is a necessary first step in larger-scale demonstrations and com-

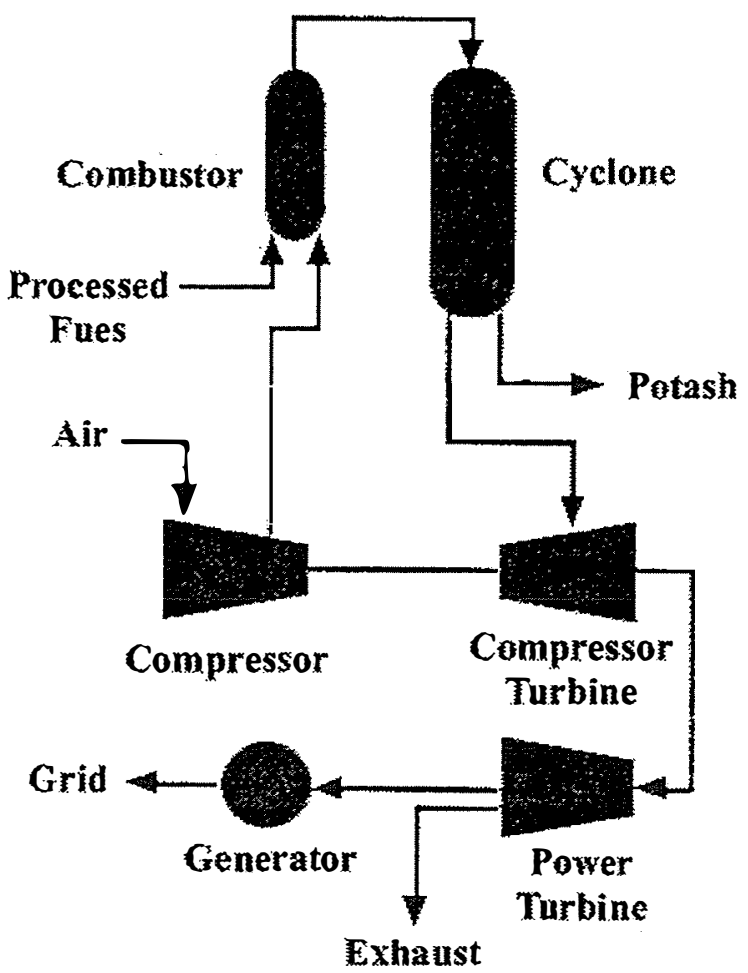

\author{
EXHIBIT 6.2-1 \\ BIOTEN \\ Direct-Fired Combustion Turbine
}


mercialization. Currently, the BIOTEN facility is rated at $5 \mathrm{MW}$ net and in the short-term, plants using this technology are expected to stay below $25 \mathrm{MW}$. Larger systems and higher cycle efficiencies may be possible with modifications that would include combined cycle configurations.

Also, much of the specific performance information obtained for this report reflects information provided by BIOTEN. ${ }^{76}$ Although the BIOTEN system does not represent all the direct-fired combustion turbine designs (such as those under development by Power Generating Incorporated), the availability of performance data and the apparent success of the demonstration unit make this system a likely competitor in the near-term biomass power market. Competitive units would be expected to meet or beat the system performance data presented. A diagram of BIOTEN's facility is provided as Exhibit 6.2-1.

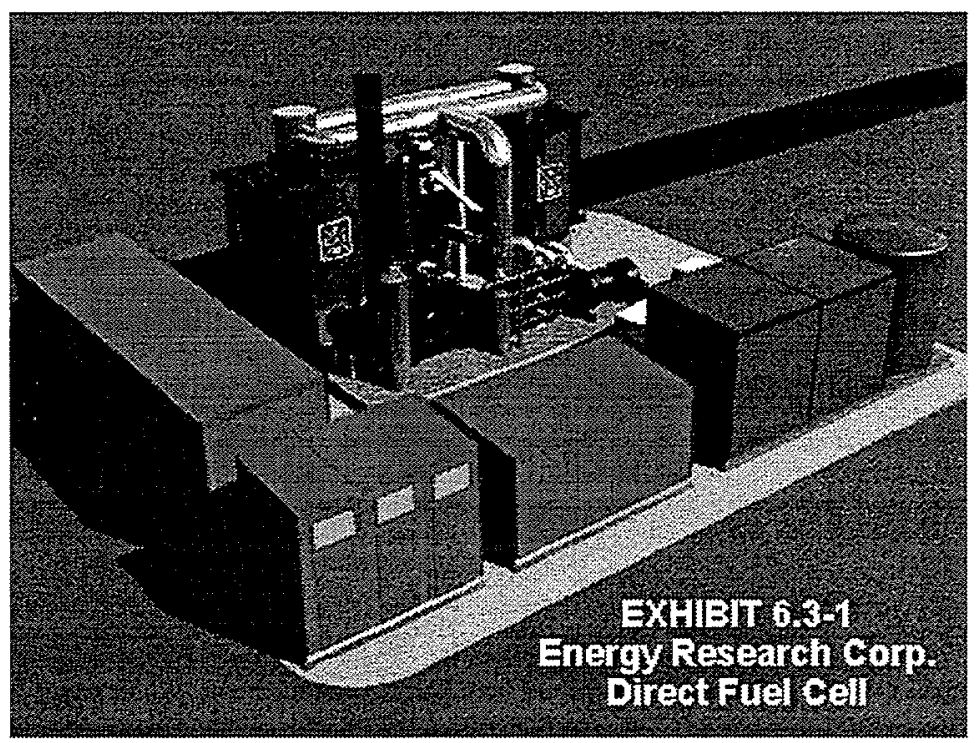

\subsection{Fuel Cells}

Currently three types of fuel cells are receiving most of the attention from researchers and pilot project developers; phosphoric acid (PAFC), molten carbonate (MCFC), and solid oxide (SOFC). Of these, PAFCs are furthest along in development. In fact, more than 40 MW of PAFC demonstration units operate around the world. They range in capacity from about $25 \mathrm{~kW}$ to $11 \mathrm{MW}$. These units, which operate mostly on natural gas, have efficiencies between $37 \%$ and $42 \%$. However, cell lives, voltage decays, and leakage problems have somewhat dampened expectations for these systems. MCFCs offer potentially higher efficiencies (50\% to 60\%) than PAFCs, with some additional benefits. Cells may be less costly to fabricate, and the rejected heat is high enough to be used in combined cycle or cogeneration applications. Several pilot projects, such as the 2-MW Santa Clara project, are under way. SOFCs are also now being tested at several facilities. Westinghouse has already delivered $25-\mathrm{kW}$ units and is expected to deliver a $100-\mathrm{kW}$ unit. Efficiencies for these systems are also expected to be very high, as are the operating temperatures. These high operating temperatures may be useful in cogeneration or possibly in combined cycle operation. SOFCs feature solid-state cell elements and simpler designs. However, MCFCs have the advantage of being able to convert more of the gas constituents (carbon monoxide and methane as well as hydrogen) into electricity; this makes them even more suitable for power generation that uses low- $\mathrm{H}_{2}$ gases such as those derived from biomass. Therefore, most of the information provided for the remainder of this report will focus on the use of MCFCs for biomass power generation.

Adapting MCFCs for use with biomass fuels will require biomass gasification. Coupling of a biomass gasifier and an MCFC has not yet been demonstrated. However, gasification will probably be accomplished using a variety of commercially available units or gasifiers currently under development. Effective gas cleanup will be of utmost importance in implementing this technology. The presence of even low levels of trace metals, halogen compounds, sulfur, tars, oils, and arsenic may adversely affect the fuel cells' efficiency and service life. On the other hand, coupling these systems may provide opportunities to take advantage of thermal and chemical synergies that have yet to be determined. The success of this type of power generation system will probably depend on the effective selection of equipment, and the extent to which components can be modified

\footnotetext{
${ }^{76}$ J.W. Rizzie, F.M. Picker, W.W. Freve, Jr., 1996, Startup and Operation of a Biomass-Fueled Combustion Turbine Commercial Demonstration Plant
} 
without large sacrifices in efficiency. Refer to Exhibit 6.3-1 for an illustration of a possible biomass-based fuel cell.

\subsection{Biomass-Integrated Combined Cycles}

BIGCCs promise some of the highest biomass power efficiencies that use technologies well along in development. A number of gas turbine manufacturers have stated that they will honor the warranties on their engines if low-Btu, clean alternative fuels are used in some of their machines. In fact, there is considerable interest by these manufacturers in exploring the marketing and sales opportunities associated with these cycles. The development of these systems is helped considerably because at least some major componnents of these systems represent proven technology. The gas turbines, steam turbines, and generators in these plants would be configured like their fossil-fired cousins. The DOE coal gasification program has also provided relevant data to allow BIGCC performance estimates to be refined. Further, except for the gasification plant, power

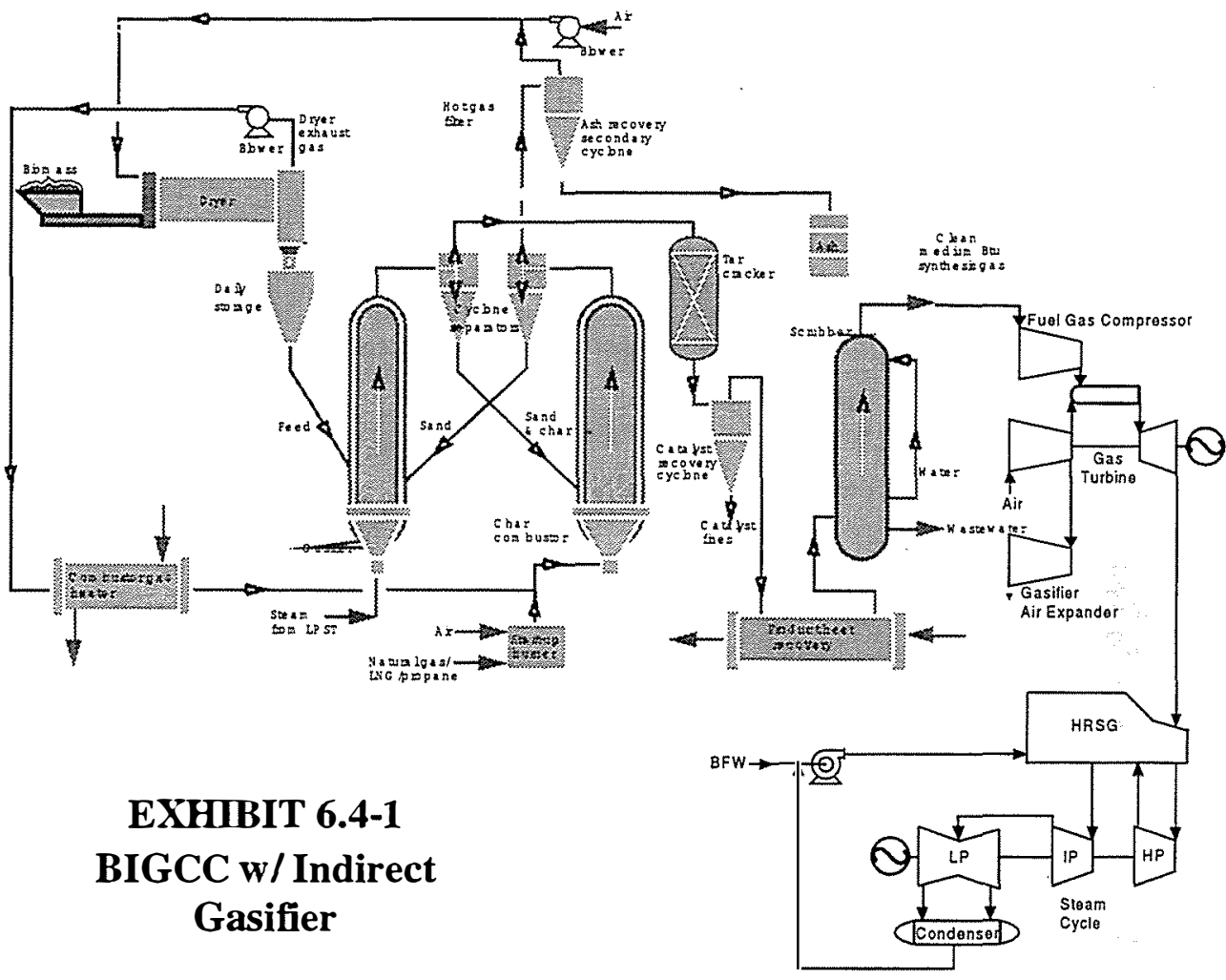
generators are familiar with this type of system, and BIGCCs may attract project developers who are reluctant to implement more exotic concepts such as fuel cells.

However, BIGCCs represent the upper bound of DG technologies because they are likely to be most economical in the 20- to 80-MW range. Certainly, if power is being supplied to a small cluster of villages or to a single commercial user, this would be too much electricity. More likely, these systems will be used to meet the power or thermal needs of industrial users (possibly captive), in grid stabilization, or in mini-grid environments.

Gasification of biomass presents the same problems in this configuration as it does in some other systems reviewed in this report. For example, product gas must be free of erosion that releases particulates or compounds that would contribute to turbine blade fouling.

Many gasification processes are all under development. A debate is ongoing on the applicability of each process to various biomass power generation technologies. Of concern in selecting these technologies for application in BIGCCs is the cost of the system, the heating value of the product gas, the pressure and temperature of the product gas, maintenance, and the impact on overall efficiency in delivering the gas to the combustor of the gas turbine. Refer to Exhibit 6.4-1 for a diagram of a BIGCC with indirect gasifier. Figure 6.4-2 lists each technology and likely economic size ranges. 


\subsection{Cost of Electricity Comparison: DG versus Central Grid}

A number of methods have been used in other studies to attempt to quantify the possible benefits of distributed power generation. These reports often focus on calculating the avoided costs of using such systems, and usually include such items as reduced T\&D line and equipment capital costs and reduced transmission losses. They may also include less direct cost savings such as those that result from increased productivity through higher system reliability. These cost savings are often translated into a $\mathrm{COE}$ value that can be subtracted from the estimated busbar COE of a given DG system and then compared to the busbar COE of a central grid station. Further, these comparisons are of ten made against the COE of peaking capacity at the plant. Peaking power is usually more expensive to produce than baseload generation.

This analysis will take a slightly different approach for several reasons. First, many of the analyses described earlier do not depict the real cost of power generated with DG technologies. For example, increased productivity that results from increased system reliability may be a benefit of DG systems. However, these cost savings are difficult to quantify and greatly depend on specific situations. Other avoided costs may include emission credits and tax incentives. Unfortunately, quantifying the financial impact of unwritten (or in some cases under-enforced) environmental policies is also highly speculative. Instead, in the short term the economics of DG systems will more likely be required to stand on the merit of cost savings that can be realistically estimated and included in a project developer's income stream, and not on the indirect benefits that may accrue. Lastly, avoided cost calculations can, in some cases, unnecessarily complicate the point of comparing DG and central grid generation - the COE to the consumer. Although several simplifying assumptions have been used, the comparisons between the selected biomass technologies and the large coal-fired power plant presented in this report are intended to provide the reader with a general understanding of:

- The possibility that technology improvements may improve the cost competitiveness of biomass based technologies

- The importance of avoiding long T\&D lines in the cost comparison between DG and central grid power.

This section begins by identifying the costs and performance parameters necessary to quantitatively compare the economic benefits of DG technologies powered by biomass to a new central grid, coal-fired power station. A number of issues and parameters are important to accurately represent this comparison. Typically these include plant capital costs, O\&M costs, T\&D costs, fuel costs, and load profiles. Additional effort has included an investigation of the plant capital cost savings that may be realized by developing the biomass power generation technologies themselves. Specifically, the COE calculations for each biomass DG technology are adjusted to include estimates of cost reductions that may be realized through economies of scale and production at several levels.

\subsection{Cost of Electricity: Description of Components}

The analysis presented in upcoming sections involves sensitizing the COEs for each technology to a number of key variables: capital costs, fuel costs, $O \& M$ costs, and T\&D costs. The resulting number of sensitivities necessitated a shorthand approach to estimate the COEs. Therefore, each technology's COE was assumed to be composed of: 


$\begin{array}{ll}\text { Capital Costs } & (\phi / \mathrm{kWh})+ \\ \text { O\&M w/o fuel } & (\phi / \mathrm{kWh})+ \\ \text { Fuel costs } & (\phi / \mathrm{kWh})+ \\ \text { Transmission Costs } & (\phi / \mathrm{kWh})+ \\ \text { Distribution Costs } & (\varnothing / \mathrm{kWh})= \\ \text { Total COE } & (\phi / \mathrm{kWh})\end{array}$

No consideration will be given to Indian state- and federal-level subsidies in the comparative analysis except for a tax break granted to renewable power generation explained later. Although these subsidies exist in varying degrees for power generation throughout India, the extent biomass power will be affected is unclear. All cost estimates are presented in 1996 dollars.

As part of this report many various sensitivity analyses, whose purpose is to provide insight into the value of biomass DG relative to central grid coal-fired generation, will be performed. A brief description of the analyses is listed below and will be a point of reference in forthcoming discussions.

Capital Costs Sensitized to:

Production Progress Cost (Leaming Curve) reductions

Economies of Production

Economies of Scale

Fuel Costs Sensitized to:

Biomass fuel cost-two cases, low and high fuel cost

Transmission and Distribution Costs Sensitized to:

Transmission line lengths

\subsection{Assumptions That Affect Capital Cost Calculations for COE Analysis}

Because of the number of variables involved, calculating the impact of capital costs on the COEs for each technology examined in this report was the most complex portion of the COE calculations. Major variables include equipment manufacturing fixed costs, equipment manufacturing variable costs, profit margins and resulting retail sales price, product demand, plant installation labor costs, and plant installation materials costs. The values of these factors are unknown for emerging biomass power technologies. Therefore, the capital cost estimates, and their impact on the COEs, are sensitized on a number of parameters and rely heavily on the use of manufacturer data (where available), "best guess" estimates of the costs associated with manufacturing and plant construction, cost analogs, and average values. Although much effort has been put forth into creating these estimates, they should not be viewed as the actual costs forecast by the manufacturers, but as providing some perspective on how the biomass technologies will compare to the central grid plant over time. Additionally, all these technologies are assumed to be on the verge of commercialization, and no cost reductions that may result from major scientific breakthroughs are assumed in any of the forecasts.

\subsubsection{Learning/Progress Curves, Economies of Production and Scale}

Since the empirical discovery of production cost improvements and the 1936 publication of the first article on learning curve theory (Wright 1936), various cost reduction models have been proposed. There are also many interpretations of production cost improvements, which often cause confusion about the production improvement effect being discussed. Generally, however, there are three types of cost improvements: (1) learning curves; (2) manufacturing or production economies; and (3) and scale economies.

Much of the confusion can be traced to learning and economies of scale, which can occur at various levels between the time components are manufactured to the time they are eventually installed into a power plant. Additionally, these types of cost reductions may not be mutually exclusive, and in practice may be extremely 
difficult to quantify given the complexity of modem cost accounting methods and cost allocations. Therefore, this report uses some simplifying assumptions to clarify some of this confusion, and to describe the potential impact of each type of cost reduction and how biomass DG technology may benefit.

\section{Learning Curves (Progress Curves)}

A learning curve describes the phenomenon by which the time per cycle to perform a particular task decreases as the number of repetitions of the task increases. Typically, the effect is strongest when a single product is produced in a single factory by the same manufacturer. As one might expect, learning can occur in a number of ways and for a variety of tasks. As an example, the manufacturer of key equipment may expect to see a decrease in production costs as workers become more efficient in assembling or manufacturing components (equipment cost reduction through learning). Similarly, as a construction contractor repeatedly builds the same type of plant, contingency costs could be reduced and the overall construction costs could diminish over time (construction cost reduction through leaming). This report these two types of learning discussed independently, as they will have different effects on the technologies examined.

Learning Curves at the Manufacturing Facility. Leaming occurs at various levels at a manufacturing/assembly plant. Original equations for learning were based on empirical observations regarding the noticeable decrease in direct labor time spent on the manufacturing or assembly of a part relative to the cumulative number of parts produced. All other things being equal, this would translate into a reduction in the per-unit labor costs, and overall lowered per-unit production cost. The impact of this type of learning is based on elements such as the complexity of the task, the capabilities of the worker, the amount of worker training, and the level of automation in the process. However, observed cost reductions are not limited to the impact of the amount of time the individual worker spends on each part. The entire manufacturing facility can exhibit learning. The factors that influence the entire organization's learning include the improvements in $^{77}$ organization, in the dimensions of the pieces to be assembled, in work methods, and in the means of production (new machines), as well as an increase in the skill of employees (human learning).

This organizational learning (which includes human learning) may now be considered more general and can be referred to as production progress. In production progress, not only is direct labor spent on each unit reduced, other indirect costs may be reduced on a per-unit basis. For example, suppose the manufacturing process of a particular product includes the manufacture of two components that are eventually glued together. After producing 1,000 of these units, the supervising plant engineer may decide that producing one part instead of gluing two parts together would be more cost efficient. The cost reductions are expected to come from less direct labor input and reduced material waste. In implementing the new process, the overall facility will become more efficient (the efficiency is influenced negatively if the workers have to be completely retrained in the new process). As a result, the manufacturing facility's learning curve, or production progress curve (which uses the same general equations as the human learning curve) may exhibit an overall higher rate of learning than could be attributed to the individual. This would lower overall costs beyond the impacts of direct labor reductions. In this example, an indirect laborer, not the direct laborer, suggests the improvement. This scenario seems to support the hypothesis that learning can occur more generally than just at the direct labor level.

Considerable research into the effects of learning on production costs has been performed. The equations to describe learning can involve a great number of terms intended to capture the impact of various levels of learning for each subtask in manufacturing and assembly processes. However, most are derived from the original equation, and a form of this equation is used in this report.

\footnotetext{
${ }^{77}$ Handbook of Industrial Engineering, New York, 1982, pp. 4.3.10.
} 


Where $\quad \begin{array}{lll}\mathrm{VC} & = & \text { Variable cost of unit }(\mathrm{X}) \\ \mathrm{K} & = & \text { Variable cost of first unit } \\ \mathrm{X} & = & \text { Number of units } \\ \mathrm{n} & = & \% \text { cost reduction for doubling in production }\end{array}$

For this report the unit cost $\mathrm{VC}(\mathrm{X})$ does not represent the entire cost of any given unit. Rather, the cost component of the nth unit produced will be sensitized to reflect cost reductions through production progress. It is not intended to reflect the variable cost defined in some cost accounting allocation methodologies-in reality the two costs would be related. Therefore, the total unit cost is described by the following equation:

Total Unit Cost $(\mathrm{X})=$ Variable Cost $\mathrm{VC}(\mathrm{X})+$ Nonvariable

Equation 7.2-2

This equation assumes that unless the unit or the manufacturing/assembly process is radically redesigned or bulk discounts in material costs are realized, the basic amount of fixed costs required to generate a unit remains constant on a \$/unit basis. The nonvariable costs include consumables such as plastic or metals, water, or chemicals required in the assembly/manufacturing process. Other costs that might remain fixed (nonvariable) over the production of a certain number of units. These would include costs such as allocations of equipment and facilities costs. These costs are explained in more detail in the subsection entitled "Economies of Production." Although the above equation is conservative, as some reduction in materials cost will probably occur in all DG systems, this provides a lower bound to the cost reductions and reduces the likelihood of obtaining unreasonably low cost estimates. Detailed breakdowns of manufacturing costs and their relationship to developer/manufacturer estimates of final installed costs are unavailable. For lack of more specific information, an estimate of $30 \%$ fixed costs and $70 \%$ variable costs was developed from another source. ${ }^{78}$

All equipment costs for a given power plant should be sensitized to production progress. For example, the BIGCC plant analyzed in this study is assumed to be composed of a gasification plant, a gas-fired turbine, a steam turbine, and balance-of-plant equipment. Of these major components, only the gasification plant would represent newly commercialized technology, and is therefore the only part of the total plant equipment costs that is likely to significantly benefit from production progress or other manufacturing-based economies. Even more specifically, only the variable cost of manufacturing a gasifier are assumed to be affected by production progress. The following equations summarize the assumed relationship between the various costs examined and the initial installed capital cost.

Totaled installed costs $\quad=\quad$ construction labor costs + plant equipment costs

Plant equipment costs $\quad=\quad$ new technology equipment + commercial equipment

New technology equipment $\quad=\quad$ variable manufacturing costs + nonvariable manufacturing costs

Given these relationships, only a portion of the total installed costs (Variable Manufacturing Costs) will ultimately be sensitive to production progress.

Limited material is available on the values of the production progress cost reduction exponent ' $n$ ' that have been experienced by manufacturers (this exponent represents the rate at which costs are reduced as cumulative production doubles). Often the value of many inputs into production progress curves for any facility/ manufacturer are proprietary. However, some general data are available and were used to compile this report.

\footnotetext{
${ }^{78}$ Based on overhead allocations found in, McLanahan, J.Craig, Cost and Error Characteristics of Three Cost Accounting System

Types: Full Cost Accounting, Marginal Costing, and Activity Based Costing, Journal of Cost Analysis, 1994, p. 141. Assumed overhead allocations approximately equal to relative costs in typical manufacturing process.
} 
The exact exponents applied to each DG technology will be described in the specific discussions of that technology's costs.

Exhibit 7.2-3

Sample of the Percent Production Progress Found in Various Industries ${ }^{79}$

\begin{tabular}{|l|c|}
\hline Source & $\begin{array}{c}\text { Percent Production } \\
\text { Progress }\end{array}$ \\
\hline Volkswagen, 1945 to 1949 & 40 \\
\hline Volkswagen, 1950 to 1954 & 20 \\
\hline Twenty light alloy products & 20 \\
\hline Repair of goods wagon & 20 \\
\hline Home construction & $14-27$ \\
\hline Welding of thin steel & 30 \\
\hline Airplane production & $25-30$ \\
\hline Shipbuilding & $10-26$ \\
\hline Vehicle bodies & $20-30$ \\
\hline German armament industry & $18-35$ \\
\hline Railway carriages & $7-25$ \\
\hline
\end{tabular}

Learning Curves at the Construction Site. It is evident from the list provided in Exhibit 7.2-3 that manufacturing or assembling almost any product can reduce costs through production progress. Further, processes that require a great deal of assembly benefit more from learning than do machine-paced processes ${ }^{80}$ This suggests that construction costs may also be reduced through learning. Additionally, larger, more complex power plants would benefit more from cost reductions that result from leaming than do smaller, extremely modular systems. However, a certain degree of caution should be used in applying this concept. The same complexity that may provide a higher potential for learning curve-based cost reductions for larger fossil-fired plants than for smaller plants, may also introduce a higher potential of cost overruns because of unexpected costs such as delays in component deliveries. Therefore, the larger cost reductions implied in some of the analogs listed earlier may be more difficult to obtain consistently. The analogs provided are part of a report that was published in 1964. Undoubtedly, manufacturing and assembly processes have changed significantly in 30 years, with a tendency to become more reliant on automation, which usually lowers the overall cost reduction potential that result from learning.

A more timely discussion of learning curve effects on construction costs was provided by the Electric Power Research Institute (EPRI) in testimony before Congress that supported a deployment scenario for the third

\footnotetext{
${ }^{79}$ De Jong, J.R., 1964, Increasing Skill and Reduction of Work Time, Time and Motion Study, September, pp. 28-41.

${ }^{80}$ Stump, E.J., 1987, “Composite Leaming Curves for Fast Estimating,” Journal of Cost Analysis, vol. 5, no.1, pp. 59-69.
} 
round of clean coal technology. During deployment, EPRI hypothesized that the performance and reliability risks of a new technology are quantified, resolved, and reduced as operational experience grows with successive demonstrations. Contingencies on design and equipment are reduced as confidence and reliability increase. The U.S. Department of Energy (DOE) incorporates this concept of declining costs through continuous reductions in uncertainty by including a contingency allowance in construction project cost estimates (DOE 1983). The contingency allowance depends on the status of design, procurement, and constructions and on the complexity and uncertainties of the project's component parts. Getting to the Nth plant was also discussed in the DOE biomass energy program planning (DOE 1994). In a discussion that follows the lines of the EPRI testimony, DOE posits that cost improvements can be made incrementally during the commercial deployment of a new technology.

As further support, the Rand Corporation reports as much as a $30 \%$ reduction in costs of building a second synfuel plant under certain conditions: (1) the size of the first pioneer plant is limited to a single commercial-scale module; (2) the pioneer plant experiences prolonged start-up; (3) the second plant does not start until the pioneer plant has 5 to 10 years of operational experience; (4) designers of the second plant have access to the results from pioneer plants; and (5) the first and second plants have similar site characteristics (RAND 1976).

In general, the literature seems to support the relationship that in field construction, a second plant built at the same site costs about $90 \%$ of the first. This impact will be very important to this analysis as it relates to the capital costs associated with the 1,200-MW coal plant modeled.

\section{Economies of Production}

Economies of manufacturing or production (as defined in this report) represent another means by which perunit production costs can be reduced, and are not necessarily directly related to production progress curves. Perhaps the best way to illustrate the difference is with a simplified example. Suppose plant A manufactures 100 widgets/day at a cost of $\$ \mathrm{X} /$ unit, in two 8-hour shifts. Eventually market conditions become such that the company that owns the plant would like to increase production and decides to add an additional 8-hour shift to increase production to 150 units/day. Assuming the direct labor and materials costs for the parts being manufactured remain unchanged on a $\$$ /unit basis (materials costs may actually be reduced through improved bulk discounts and could be attributed to the economy-of-manufacturing phenomenon), the plant should experience a moderate reduction in its $\$$ /unit cost because facilities costs and indirect labor are leveraged over the larger number of units being produced. This type of cost reduction is not due to increased learning of the facilities' workers, but is a function of the production rate, which allows the plant to leverage indirect costs more efficiently. However, in examining production progress curves closely, at least part of the cost reduction per unit may be a result of increased manufacturing throughput (less labor spent on each part means that more parts are produced per unit time). Therefore, although economies of production do not necessarily involve learning, production progress is likely to include increased throughput and will introduce some economies of production. This study therefore assumes that production progress will drive most cost reductions expected for the technologies examined; a smaller but significant cost reduction is assumed for economies of production.

Estimating economies of production/manufacturing requires a fairly detailed knowledge of a given plant to estimate how larger or higher-producing facilities may perform. This information is not yet available for the technologies examined in this report. Therefore, this analysis assumes that the manufacturing facilities are operating at a capacity consistent with the work rates of the employees, and that the length of shifts and extent of the production lines are ideally optimized for the plants that produce the DG systems or components (as reflected in the initial unit costs). Information provided as part of a report entitled The Effect of Scale and Quantity on the Cost and Performance of Energy Technologies: A Literature Review ${ }^{81}$ states that for the

\footnotetext{
${ }^{81}$ Hill, D., Effect of Scale and Quantity on the Cost and Performance of Energy Technologies: A Literature Review.
} 
production of heliostats, a 35\% increase in production volume yielded only a 5\% decrease in unit cost. This moderate effect formed the basis for the cost reductions assumed in this study, which are explained in more detail in section 7.6.

\section{Forecasted System Demand}

When examining the impacts of production progress and economies of manufacturing, the number of units and the time period in which they are produced must be considered. Although indisputable, accurately estimating how many systems will be installed during any given period is beyond the scope of this study. The contradiction this appears to create is resolved by estimating the potential sales of these units based on estimates of future power requirements of India and other large electricity markets.

Estimates of yearly production volumes for each biomass system examined are based on two market potential groups: (1) the low market potential group, which is based solely on the projections of future electricity requirements of India, and (2) the high market potential group, which is based on the future electricity requirements of India, China, and OECD countries combined (sufficient data were not available to support a global analysis for the high potential case). For reasons alluded to in previous chapters, biomass-based DG systems are anticipated to be deployed in rural areas more than in urban centers. Therefore, estimating the percentage of total projected electricity demand that was due to rural consumption was necessary. Information on electricity consumption was unavailable for all data sets, so other indicators (such as rural population) were used as surrogates, if the electricity forecasts could be broken down by customer class. Projected consumptions by consumer type were unavailable, but an average of the historical percentage of total consumption for each class was calculated and applied to all future time periods. Although the percentage of total electricity consumption for each class has not been constant in the past, the variation over the sample time periods was less than $10 \%$ for any class or country group. The impact of any error introduced by the assumption of constant percent demand by class is considered low relative to more significant assumptions. The electricity requirements of the rural sector are calculated using the forecasted demand by sector and rural electricity consumption data to determine the potential market for rural DG technologies. Biomass technologies represent only one type of DG technology that may be applicable to the rural sector, so an additional market penetration factor was applied. Each biomass technology was assumed to capture only $1 \%$ of the potential rural DG power market. This probably represents a conservative estimate of these systems' potential, because some will not be restricted to using only biomass fuel or in stationary power systems (Stirling engines, fuel cells). However, competition from conventional power systems (which are commercially accepted and initially less expensive) and grid extension projects will probably limit initial market penetration, so a low constant penetration was assumed.

Yearly production rates are calculated by subtracting the forecasted generation requirements of successive time periods to calculate incremental demand. Because forecasts were available only in 5-year increments, yearly production is calculated by dividing the incremental generation into equal segments. The total forecasted generation is converted into the number of units based on the technical data, such as system size, supplied for each system.

\section{Economies of Scale}

Economies of scale may also provide a means to reduce overall plant costs for some of the technologies investigated. There appear to be cost reductions caused by scale-up in a linear relationship for large pieces of stationary equipment such as boilers and (to a lesser degree) for rotating equipment such as turbines. Engineering cost estimation bases this phenomenon on the relationship of the volume of a sphere to its surface area. Traditionally, the six-tenths power law stated that cost increased by only half with a doubling of plant size, reducing cost per unit to $75 \%$. Thus the six-tenths fact rule (Peters and Timmerhaus 1968) or six-tenths power law (Comtois 1977) states: 


$$
\frac{\text { Cost of Unit } A}{\text { Cost of Unit } B}=\left(\frac{\text { Capacity of Unit } A}{\text { Capacity of Unit } B}\right)^{s}
$$

where the scale factor $(\mathrm{s})=0.6$

If the capacity of unit $\mathrm{A}$ is twice that of unit $\mathrm{B}$, its cost is about 1.5 times as much and thus cost per unit of capacity is $(1.5 / 2)$ or $75 \%$ as much. However, although much research and effort has been expended on the subject, there does not seem to be universal agreement on the impact of these economies on the construction of power plants, or even what cost items should be included in the analysis. Further, the large body of engineering data that would support the expectation that economies of scale should occur (provided everything goes right) may underestimate the probability that things will go wrong, thus reducing the actual economies of scale realized. Statistical studies done by Mooz (1980) and Komanoff (1981) used multiple regression analysis to establish a correlation between dependent variables of plant construction costs and construction duration with a variety of independent or explanatory variables including temporal trending variables, scale variables, and learning effect variables. Scale factors were not as important as the traditionally accepted standard, (i.e., a cost reduction to $60 \%$ for each doubling of capacity). Mooz found no sizeable diminution in unit cost as the size of the plant increased. Komanoff found that the capital cost per unit of nuclear plant capacity varied with the -0.2 power of the plant megawattage; therefore, a doubling of plant size could reduce cost per kilowatt to $87 \%$. For coal plants, Komanoff found only a weak scale effect: a 3\% reduction for a doubled size, with only $82 \%$ confidence in the result.

On the other hand, the following analysis suggests that for natural gas-fired combined cycle plants, there may be a significant scaling effect.

Exhibit 7.2-4 Average Costs and Efficiencies of Natural Gas Combined Cycle Plants

\begin{tabular}{|c|c|c|}
\hline Plant Size & $\begin{array}{c}\text { Avg. } \\
\text { LHV } \\
\text { Efficiency }\end{array}$ & $\begin{array}{c}\text { Avg. Turnkey } \\
\text { Price }(\$ / \mathbf{k W})\end{array}$ \\
\hline Less than $35 \mathrm{MW}$ & $45.3 \%$ & 807 \\
\hline Greater than or Equal to 35, Less than $70 \mathrm{MW}$ & $48.5 \%$ & 729 \\
\hline Greater than or Equal to 70 , Less than $140 \mathrm{MW}$ & $49.8 \%$ & 729 \\
\hline Greater than or Equal to 140 , Less than $280 \mathrm{MW}$ & $52.7 \%$ & 468 \\
\hline Greater than or Equal to 280 , Less than $560 \mathrm{MW}$ & $55.6 \%$ & 474 \\
\hline
\end{tabular}

A simple graphical analysis of these data suggests that scaling factors for these plants may range from between 0.67 and 0.95 (an average value of 0.82 was used in the upcoming BIGCC cost calculations). Although the analysis used in this report is too simple to allow definitive conclusions, it suggests that efficiency increases and installed cost on a $\$ / \mathrm{kW}$ basis decreases with size for these plants. Also, the two variables are likely related somehow, and the exact impact of scale would require a more detailed study.

${ }^{82}$ Gas Turbine World Handbook, vol. 17, 1996, Pequot Publishing. 
The extent to which the biomass DG systems examined in this report will benefit from economies of scale is also unclear. However, in general the larger units examined will probably be better suited to take advantage of large scale-ups than, for example, the Stirling engine technologies. To that end, specific assumptions for each technology were made and are treated as part of the overall cost discussions in section 7.6.

\subsubsection{Estimates of Biomass DG Plant Construction Costs}

Information about the first commercial unit's installed capital costs (on a $\$ / \mathrm{kW}$ basis) for each $\mathrm{DG}$ technology was the starting point for all calculations that involved capital costs. This information was derived from a variety of sources, including technical papers, joumals, and technology developer/manufacturer estimates. However, in all cases these estimates were provided based on the assumption that the plants were to be constructed in the United States.

Specific assumptions for each biomass DG system are reserved for the individual technology sections found toward the end of this chapter. However, certain general assumptions were used to sensitize total plant costs to a variety of factors. These are explained below. Topics to be discussed include construction cost reductions for in-country labor rates and construction cost reduction through learning.

Construction Cost Reduction for In-Country Labor Rates. As this study focuses on employing these technologies in India, the total installed costs should be adjusted to reflect lower construction labor costs in India relative to the United States. To adjust for the differences in labor rates, we estimated that $13 \%$ of the total plant installed costs for the direct-fired combustion turbine, fuel cell, and BIGCC power systems were construction labor and $87 \%$ was composed of costs not sensitive to labor rate (this calculation is based on sources and specific calculations can be found in the Appendix). For the Stirling systems, the calculation of required construction labor was based on discussions with Caterpillar, a manufacturer of small diesel gensets. These systems were presumed to be similar to the Stirling systems in that they are small, modular, and setup is expected to be limited to site leveling, installation of concrete slabs, and connection to switchyard hardware. With this in mind we estimated that only $8 \%$ of the total plant cost (TPC) will be attributable to construction labor. Specific assumptions and calculations regarding construction labor costs can be found in the appendix.

Using information from the International Labor Organization ${ }^{83}$ (ILO) on the hourly cost of construction labor in the United States and India, a ratio of relative costs was calculated. This ratio was then applied to the estimates of U.S. labor costs and recombined with the estimate of nonlabor rate-sensitive costs. The application of this ratio reduced plant costs by almost $13 \%$ in the case of the larger systems and $8 \%$ in the Stirling systems, as average Indian construction wage rates appear to be about $\$ 0.10 / \mathrm{h}$. The large difference in wages between the two countries was also apparent in the O\&M and fuel cost estimates. The adjustment of TPC for wage differences can be clarified by the following equations:

\begin{tabular}{|c|c|c|}
\hline Tot. Installed Plant Costs (US) & $=$ & U.S. Rate-Sensitive Costs + U.S. Non-Rate Sensitive Costs \\
\hline Labor Rate Sensitive Costs & $=$ & (Total Installed Plant Costs) $* 0.13$ \\
\hline Materials@BOP Equip. Costs & $=$ & (Total Installed Plant Costs) $* 0.87$ \\
\hline Indian Labor Ratio & $=$ & $\begin{array}{l}\text { (India Const. Labor Rate/U.S. Const. Labor Rate) }=0.0080 \\
\text { where U.S. avg. wage }=\$ 15.04 / \mathrm{h} \text {, India avg. wage }=\$ .12 / \mathrm{h}\end{array}$ \\
\hline nd & $=$ & (U.S. Labor Costs * Indian Labor Ratio) \\
\hline ndia) & $=$ & Indian Labor Costs + U.S. Materials \& BOP Equip. Cost \\
\hline
\end{tabular}

${ }^{83}$ International Labor Organization, 1993 \& 1994, Statistics on Occupational Wages and Hours of Work and on Food Prices. 
This adjusted, or Indian TPC, was then used in all future calculations that involved total capital expenditures. This calculation inherently assumes that equipment costs will be the same in the United States and India. Assuming similar wage differences in the manufacturing sectors of these countries, manufacturing major plant components in India could further lower overall capital costs by reducing equipment costs.

Construction Cost Reduction through A\&E Learning. Previous discussions have provided background on the possible impacts of the construction contractor's learning curve on plant costs and seems to suggest that some reduction in costs should be expected over time. However, the difference in Indian and United States construction labor rates nearly eliminated all construction labor costs for the TPC estimates. Any additional reduction realized through leaming (by reducing contingency costs, for example) fell within the error of more significant assumptions, so no further cost analysis was performed in this area.

\subsubsection{Capital Costs in COE Analysis}

The carrying charge calculations are based on the EPRI TAG methodology. Annual carrying charges are equal to the sum of return on debt, returm on equity, income tax, and other miscellaneous taxes, which are calculated from the TPC. The analysis assumes that all plants are developed by out-of-country developers and that a $75 / 25$ debt/equity ratio with corresponding rates of retum of $12 \%$ and $22 \%$ would be sought. Although a $22 \%$ rate of return on equity is higher than the $16 \%$ cap set by the Indian government, we hypothesized that the renewable technologies represented higher risk investments and investors would need higher rates of retum. For the coal plant a retum of $16 \%$, which reflects a lower perception of risk, was used. Another fundamental difference between the finance assumptions for the renewable technologies and the coal plant was plant depreciation schedule. The coal plant faces a conventional, 20-year straight-line tax depreciation schedule, but renewable energy projects in India receive preferential tax treatment. They are allowed to expense 100\% of their capital cost in the first year of operation, so they face only a 1-year depreciation schedule. This affords the DG systems a large tax advantage for the life of the plant.

\subsection{Assumptions That Affect O\&M Cost Calculations}

O\&M costs are calculated consistently with the methodology described for TPC. Using ILO wage information and U.S. O\&M cost estimates for each technology, we could estimate the costs of operating the various power plants in India. The impact of assumed wage rates on the cost estimates was as substantial as it was for TPCs as estimates of the two country's O\&M wage rates differed by several orders of magnitude.

\begin{tabular}{|c|c|c|}
\hline O\&M w/o fuel costs $($ Us) & $=$ & 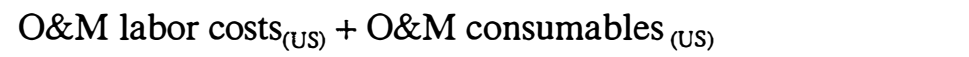 \\
\hline O\&M w/o fuel costs ${ }_{\text {(INDIA) }}$ & $=$ & O\&M labor costs ${ }_{(\mathrm{INDIA})}+\mathrm{O} \& \mathrm{M}$ consumables $(\mathrm{US})$ \\
\hline O\&M labor costs (INDIA) & $=$ & $\begin{array}{l}\text { O\&M labor costs } \\
\text { Costs }_{(\mathrm{USD})} *(\text { Average Labor } \\
\text { where [U.S. avg. wage }(\$ 22.46 / \mathrm{h}) / \text { India avg. wage }(\$ 0.11 / \mathrm{h})]= \\
0.0044\end{array}$ \\
\hline
\end{tabular}

These equations assume that plant consumables costs are the same in both countries. Further, this analysis assumes that the same number of personnel would be used in both countries to operate similar plants. This may, in fact, not necessarily be the case. Certain unions or local laws may set minimum staffing requirements that would increase the operating costs. The cost of consumables is most probably not the same in both countries, either. However, as with the construction labor costs, the significant difference in labor rates greatly overshadows any error that may be introduced because of cost differentials in this category. Lastly, the wage data used in this calculation and all wage-based analyses represent country-wide averages. Plants in specific areas may have considerably different wage rates that would affect these calculations. However, the consistent application of these assumptions allows reasonable comparisons. Detailed calculations and assumptions regarding plant O\&M costs are included in the Appendix. 


\subsection{Fuel Costs}

Plants that use biomass will undoubtedly strive to obtain the lowest cost fuel available. The cost of fuels will inevitably vary, and predicting even average costs is speculative. However, this analysis assumes that higherand lower-cost fuels will be used in combination to meet the feedstock needs of these plants. Therefore, depending on the ratio of the amount of low- and high-cost fuels used, the average fuel cost (blended fuel cost) will vary on a $\$ / M M B t u$ basis. The two blends assumed to provide a high and low average cost scenario are:

$$
\begin{array}{lll}
\text { High avg cost } & =\quad 75 \%(\text { High-cost Fuel })+25 \%(\text { low-cost fuel }) \\
\text { Low avg cost } & =\quad 25 \%(\text { High-cost Fuel })+75 \%(\text { low-cost fuel })
\end{array}
$$

Equation 7.4-1a

Equation 7.4-1b

The high cost fuels are assumed to be equal in price to the cost of growing a dedicated feedstock on an energy farm, and were estimated with models developed by ANTARES Inc. ${ }^{84}$ for growing and processing hybrid willow. The fuel cost is estimated to be approximately $\$ 2.00 / \mathrm{MMBtu}$ in the United States. This represents current costs (using 7.5 tons/acre yields for a 500-acre farm and nominal land rental costs of \$20/acre and a $10 \%$ retum on investment), and assumes the fuel is chipped and ready to be introduced into the plant. Adjusting for average differences in agricultural wage rates between the United States and India, this cost could be $\$ 1.60 / \mathrm{MMBtu}$ for the high-cost fuel. The lower-cost fuels are assumed to be primarily composed of agricultural residues delivered to the plant gate at no cost. The cost of using the fuel is therefore reduced to handling, estimated at $\$ 2 /$ dry ton. This is approximately equivalent to $\$ 0.18 / \mathrm{MMBtu}$, assuming a higher heating value (HHV) of 5,600 Btu/lb for cereal residues. ${ }^{85}$ The average cost of each scenario described in Equation 7.4-1 can now be evaluated as follows.

$$
\begin{array}{ll}
0.75(\$ 0.18 / \mathrm{MMBtu})+0.25(\$ 1.60 / \mathrm{MMBtu})=\$ 0.54 / \mathrm{MMBtu}(\text { low-cost blend }) & \text { Equation 7.4-2a } \\
0.25(\$ 0.18 / \mathrm{MMBtu})+0.75(\$ 1.60 / \mathrm{MMBtu})=\$ 1.25 / \mathrm{MMBtu} \text { (high-cost blend) } & \text { Equation 7.4-2b }
\end{array}
$$

The high and low values are intended to represent the likely ends of the biomass fuel supply costs in any given area and provide some perspective regarding possible COEs for these systems. Advanced biomass power generation systems will probably rely initially on low-cost (not no-cost) residues and may introduce energy crop feedstock as part of their fuel blend only as it becomes available and at lower cost than alternative fuel supplies. In addition, as potential suppliers of biomass begin to realize that the residue is a valued commodity, the price of residues may rise and reduce the price differential between fuel supplies. As these effects are difficult to quantify and predict, we determined that the range presented in this study would be more representative of fuel costs than the arbitrary selection of a biomass fuel price, or presenting a "no-cost" and "energy crop high-cost" scenario. Of course, to place a real power plant in a specific
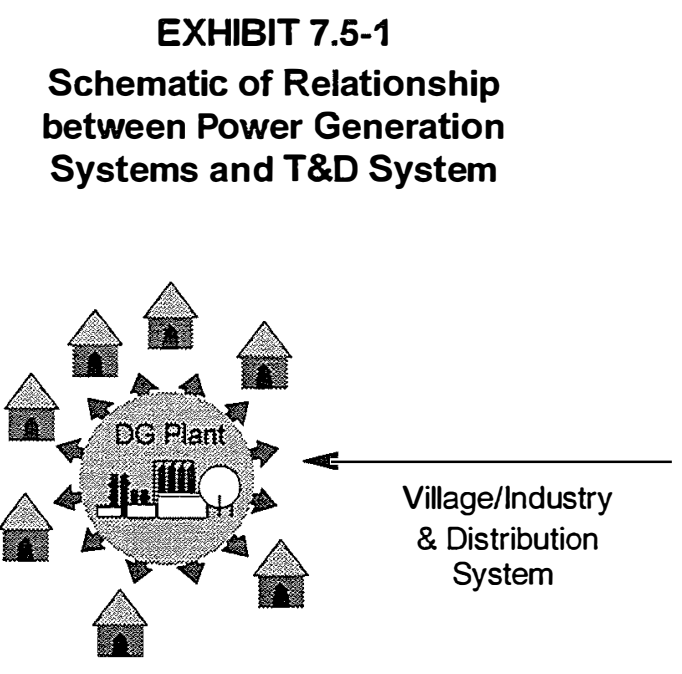

1200 MW Central Grid Plant

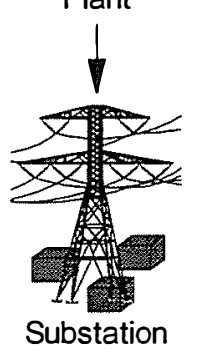

\footnotetext{
${ }^{84}$ Antares Group Incorporated, Landover, MD. These cost can be significantly lower using anticipated increases in farm size and feedstock yields.

${ }^{85}$ D. Hall, Renewable Energy: Sources for Fuels and Electricity, ch. 14, p. 632.
} 
part of India, a more complex approach to determining probable fuel costs would be needed. In fact, the amount of available resource may also rule out the use of larger biomass power generation options such as BIGCCs. On the other hand, larger facilities offer potential fuel suppliers a steady and more significant demand for their product. In a competitive biomass fuel environment, this may allow larger power plants to obtain discounts based on volume.

\subsection{Transmission and Distribution Costs, Load Profiles, and Capacity Factors}

Exhibit 7.5-1 shows the relationship between the various power generation technologies and the T\&D systems. In every distributed generation study it is important to consider these costs, as they can significantly affect the overall COEs. In this analysis several assumptions were made to simplify the comparison between the very different technologies that were evaluated. These assumptions and their impact on the analysis follow. The cost assumptions used in the analysis are based on U.S. experience derived from the fuel cell handbook ${ }^{86}$ and other U.S. technical data. Many are based on empirical calculations (such as line losses for transmission line length) and are not expected to vary because of regional differences.

\subsubsection{Distribution System Costs}

In this analysis the costs associated with the distribution lines for a new DG power plant or a new grid power plant are assumed to be approximately equal on a cent $/ \mathrm{kWh}$ basis. This assumes that both the DG system and the central grid power system would be used for the same purpose. Either the DG and central grid stations both provide a grid stabilization function and sell all generated power into the grid (no distribution system) or they sell all new power generated to new or upgraded distribution systems. This assumption is important in ensuring that on a cent/kWh basis, neither system is provided an advantage in costs because of differences in the way the new power is to be used. The economics presented in this analysis merely provide some perspective on the potential competiveness of these technologies. We recognize that there are a number of specific scenarios for which this assumption could not be made. Facilities that seek approval would have to address these issues in more depth. However, for this study the COEs of both the DG and central grid station are assumed to include the construction of new distribution systems proportional to their power output and the costs of doing so would be approximately equal on cent $/ \mathrm{kWh}$ basis regardless of technology. The actual costs of maintaining, operating, and constructing distribution lines and equipment are therefore not quantified as part of the COEs presented in this report.

\subsubsection{Transmission Lines}

Operating costs of these lines include costs of losses associated with transmission lines, their transformation equipment, and O\&M of the equipment. Based on U.S. practices, and engineering data related to equipment costs, ${ }^{87}$ we conservatively estimated that $10 \%$ of the actual costs of the grid-generated power will be accrued through the O\&M of the transmission lines and grid substations.

Capital costs of the new or upgraded facilities such as new or upgraded substation and transmission lines are estimated to be $50 \%$ of the actual costs per $\mathrm{kWh}$ for grid-generated power, plus an additional $50 \%$ of actual costs for lines $360 \mathrm{~km}$ and longer, 25\% for lines shorter than 360 but longer than $160 \mathrm{~km}$, or $0 \%$ for lines shorter than $160 \mathrm{~km}$. Although there are only three tiers to this prorating, we determined they were sufficient to represent the savings accurately. Additional costs that were considered, but not included, were the cost of VAR (reactive power) control. These costs are negligible with respect to the other costs examined, and are

\footnotetext{
${ }^{86}$ Fuel Cell Commercialization Group, 1996, System Planning Workbook.

${ }^{87}$ Fuel Cell Commercialization Group, 1996, System Planning Workbook, Washington, DC.
} 
added to the busbar COE of the central grid plant only because we assumed that the DG systems will be built at the distribution level and will not require transmission. However, the length of transmission lines required to transmit power from the grid to the local distribution system will be varied to provide some insight into how important transmission costs are in the comparisons.

The importance of including transmission costs in these types of analysis can be clearly demonstrated based on exhibit 7.5-2. Based on work presented by Rackliffe and Willis ${ }^{88}$, transmission costs alone may be as capital intensive as constructing the power plant itself. Although the exhibit shown is based on work performed in the early 1980s, it clearly shows that where transmission costs are high, efficient DG technologies may hold an overall cost advantage.

\subsubsection{Theft}

Unlike the United States, theft of electricity is considered a serious problem in India. Some sources estimate that approximately half of the $20 \%$ + line losses that have been calculated for India's electricity infrastructure are due to theft. Theft is most likely to occur at the distribution level and may be accomplished in a number of ways -routing around revenue meters, for example. The problem is serious enough that some consideration is warranted in this study. We hypothesize that DG systems will have an advantage over central grid-provided power in preventing theft. DG power is localized, and in some cases may be owned by a local private party who has a vested interest in eliminating theft. Enforcing the law and monitorring the lines may therefore be easier. We therefore assumed that the delivered COE from the central grid will be burdened by an additional cost equal to a rate of $10 \%$ of the busbar cost caused by theft. Losses caused by theft of electricity in DG systems is assumed to be zero.

\section{EXHIBIT 7.5-2}

Taken from Racliffe and Willis ${ }^{88}$

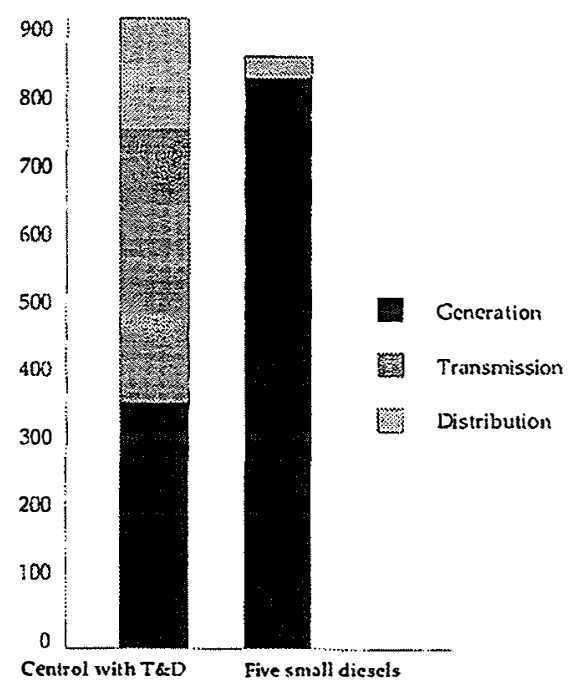

Using these assumptions the following equations are the basis for the COE comparisons in this analysis.

\begin{tabular}{|c|c|c|c|}
\hline \multirow{3}{*}{\multicolumn{2}{|c|}{$\begin{array}{l}\text { DG Delivered } \\
\text { Central Grid Delivered } \\
\text { COE)/TH }\end{array}$}} & $=$ & Busbar COE + distribution system costs (not quantified) \\
\hline & & $=$ & (Busbar COE + [(.5)*Busbar COE + TL*Busbar COE $]+(.1) *$ Busbar \\
\hline & & $=$ & $\begin{array}{l}\text { +Distribution system costs (not quantified) } \\
(1.6+\mathrm{TL}) / \Gamma \mathrm{H} * \text { Busbar COE }\end{array}$ \\
\hline where; & TL & $=$ & 0.50 for transmission lines longer than $360 \mathrm{~km}$ \\
\hline & $\mathrm{TH}$ & $=$ & $\begin{array}{l}0.25 \text { for transmission lines longer than } 160 \mathrm{~km} \text {, shorter than } 360 \mathrm{~km} \\
0.00 \text { for transmission lines longer than } 0 \mathrm{~km} \text {, shorter than } 160 \mathrm{~km} \\
\text { (1-theft } \%)=90 \%\end{array}$ \\
\hline
\end{tabular}

\subsubsection{Load Profiles}

Daily and seasonal variations in electricity demand have a real impact on the operation of DG and central grid power plants. These variations affect not only the production economics, but can also have serious implications for plant efficiencies and maintenance. Most load systems exhibit varying requirements for electricity over time, and matching these loads using the least expensive power available will provide customers with the

\footnotetext{
${ }^{88}$ Rackilffe, G.B., Willis, H.L., Distributed Generation and Storage-A New Perspective, Cogeneration and Competitive Power Journal, Vol. 10, No. 4,1995
} 
lowest-cost electricity. However, load matching requires detailed knowledge of the demand and is very site and situation specific. In rural India, residents, industries, and commercial businesses can be expected to have a wide variety of electrical demands. Deciding how much electricity any given set of customers needs, when they need it, and which technology would be optimally suited to supply it, is better left to specific case studies. For this report a more general, albeit less accurate, and simplified approach to these issues was chosen. All technologies were assumed to provide baseload generation. Although this approach does not quantify technical advantages to items such as tum down efficiencies, it does allow for determination of the trends in electricity production costs that may be possible for the systems examined, relative to fossil-fired, baseload generation. Future research that focuses on specific regions or situations in the Indian power sector, would benefit from a more rigorous treatment of this subject.

\subsection{Technology COE Calculations}

The following technology discussions are divided into three major categories: Capital Costs, O\&M Issues, and Power Output Performance and System Efficiencies. Because all represent state-of-the-art biomass power generation, we tried to collect recent information on each technology's state of development and current performance expectations. In some cases, this necessitated using developer-specific data that may narrow the perspective on the long-term application and potential diversity of the configurations of these technologies. However, these data were believed to provide the most meaningful and realistic expression of near-term biomass power generation performance. Their use not intended as an endorsement of any particular developer's technology, and the performance parameters used in this report only provide a benchmark for comparison. Additionally, all technologies have been assumed to operate "ideally" in accordance with the information supplied by the manufacturer. Information about possible problems is noted, but has not been assigned a financial impact. Some may argue that this unfairly gives more complex (often characterized as more efficient but less reliable) systems an unfair advantage, but quantifying the impact of technical problems is beyond the scope of this report. Further, all these technologies are still in the developmental/demonstration phase, and based on the information available, all are still wrestling with some important developmental issues.

\subsubsection{Stirling Engines}

Capital Costs. Two Stirling systems that hold promise are designed by Stirling Thermal Motors (STM) (kinematic) and Sunpower Inc. (free-piston). These machines can essentially be divided into two major components: a biomass gasifier/combustor component and the Stirling engine/power section (see Figures 6.2-1 and 6.2-2 for diagrams). On a $\$ / \mathrm{kW}$ basis, Stirling engines are expected to benefit significantly from cost reductions realized through production progress and economies of manufacture. The size of these systems suggests that they will compete in markets where small increments of power are needed and major components (the engine itself and the biomass combustor) will probably be manufactured in high-volume facilities that can meet the large forecasted demand. These systems will probably have the added advantage of being used for nonbiomass purposes, and in industries other than power generation. In this respect, the production volumes estimated using the DG market potentials described in section 7.2 may underestimate the rate at which these units will ultimately be manufactured. This would also underestimate the rate at which these systems would achieve significant cost reductions.

Cost reductions through economies of scale seem less likely for these systems. Restrictions on heat transfer rates through working fluid containment vessels, material properties, and other technical restrictions will probably limit the size of these machines to less than $50 \mathrm{~kW}$. Additionally, scaleup of Stirling engines may involve more exotic and expensive materials, and thus limit the effect of any scale economies. Larger power generation needs will be met by coupling, or placing multiple units on site. For the three sizes modeled in this study, no economies of scale were used. 
Cost estimates for commercial biomass-fueled Stirling engines are continually being revised and are difficult to obtain. Engine developers are, by their own admission, uncertain about their eventual cost. Fortunately, some early estimates were provided as part of a comparison between a biomass-fueled Stirling system and a diesel and gasoline-fueled generation set. The total biomass unit cost of $\$ 6,000$ for a $2.5-\mathrm{kW}(10,000$ unit production run $^{89}$ ) system is assumed in the comparison (this cost assumes U.S. labor rates). This translates to a total system cost of $\$ 2,400 / \mathrm{kW}$, or if $\$ 1,500 / \mathrm{kW}$ is subtracted for the engine/alternator, the biomass gasification system would cost $\$ 900 / \mathrm{kW}$. However, this cost is well along the production progress curve, and for this analysis we had to extrapolate system costs back to a point consistent with the unit cost of the first commercially manufactured system.

There is an additional item to consider with respect to the capital investments required with Stirling systems. Although the free-piston machines boast fewer moving parts (and therefore the potential for higher reliability and longer life) both systems are currently designed to have service lives between 30,000 and 60,000 hours. However, major manufacturers do not have sufficient operating experience with Stirling engines in power generation applications to be sure of these estimates. Further, Sunpower Inc., estimates that refurbishing its engine at the end of its life will cost only about $10 \%$ of the original investment, and although the kinematic machines available from STM may require more extensive refurbishment (many components are expected to suffer irreparable damage from fatigue failure), these systems will probably benefit from some form of manufacturer rebuild.

Comparing the COEs for a Stirling system with a service life of 6 years and a fossil plant with a service life of 30 years presents some challenge. We may conservatively assume that at the end of the Stirling engine's life it would be replaced. Neglecting the time value of money, and reductions in the price of the system, the $\mathrm{COE}$ for the next system would be approximately the same as the first and would continue to be the same into the future. Comparing the coal and Stirling systems would then be a matter of plotting the COE calculated over the Stirling's 6-year life versus the COE calculated for the coal plant over its 30-year life. However, the end of its life the entire Stirling engine will probably not be scrapped in favor of a brand new one, but rather overhauled and allowed to continue running. Presuming the overhaul represents a cost saving over the purchase of a new unit and that the original capital costs are amortized over the first 6 years of the unit, the incremental $\mathrm{COE}$ for the unit going into the future should be reduced. Over 30 years this may represent a significant reduction in $\mathrm{COE}$. An attempt to quantify this effect has been included in the COE analyses for each system, if applicable. For simplicity, this analysis assumes that refurbishment costs for a Stirling systems will amount to $20 \%$ of the initial installed costs of the original engine and will be required every 45,000 hours (based on an average of the above system lives). At an average capacity factor of $80 \%$, this translates into a total of four refurbishments over a 30-year period. On this basis, the initial purchase price was adjusted to account for additional refurbishment costs. Because these represent future capital investments, a factor to correct for the time value of money is calculated uşing the following equation.

$$
\mathrm{CAF}=1+\left[\mathrm{PV}\left(\mathrm{WCC}, \mathrm{X}^{*} 1\right)+\mathrm{PV}\left(\mathrm{WCC}, \mathrm{X}^{* 2}\right)+\mathrm{PV}\left(\mathrm{WCC}, \mathrm{X}^{* 3}\right)+\mathrm{PV}\left(\mathrm{WCC}, \mathrm{X}^{* 4}\right)\right] * \mathrm{RC}
$$

$\begin{array}{lll}\text { where; } & =\quad \text { Initial capital adjustment factor (applied to original engine cost only) } \\ \text { RC } & =\quad \% \text { Refurbishment cost relative to initial unit cost } \\ \text { WCC } & =\quad \text { Weighted cost of capital } \\ \text { PV (WCC, X) } & =\quad \text { Present value factor at WCC, year of refurbishment }\end{array}$

This adjustment does not account for future cost improvements, but it provides some reduction in COE for these systems by allowing longer operational lives than those determined by component failure. Exhibit 7.6-1 summarizes the capital cost assumptions used for the first unit at the reference scale in this analysis for Stirling

\footnotetext{
${ }^{89}$ Sunpower Inc., 1996, Better Machines for A Better World.
} 
engines. A complete description of all sensitivities and detailed calculations are included as part of the Appendix.

O\&M Issues. For the STM and Sunpower systems, biomass is first gasified. The raw product gas is combusted, and the resulting heat is supplied to the engine. By design, this process is intended to require very little pretreatment of the combustion gas. This gives this type of system a major advantage in maintainability and reliability over systems that require much cleaner product gas. $\left(\mathrm{STM}^{90}\right.$ has noted some fly ash buildup on the engine heater head after only short durations of operation. However, this problem is expected to involve relatively minor modifications and should not represent a major barrier for using biomass in commercial applications.) The capital and operating costs of the gasification system can be greatly reduced compared to systems that use cleanup processes such as hot filter cleanup that can lower overall efficiency.

\section{Exhibit 7.6-1 \\ Capital Cost Assumption Summary-Stirling Engine}

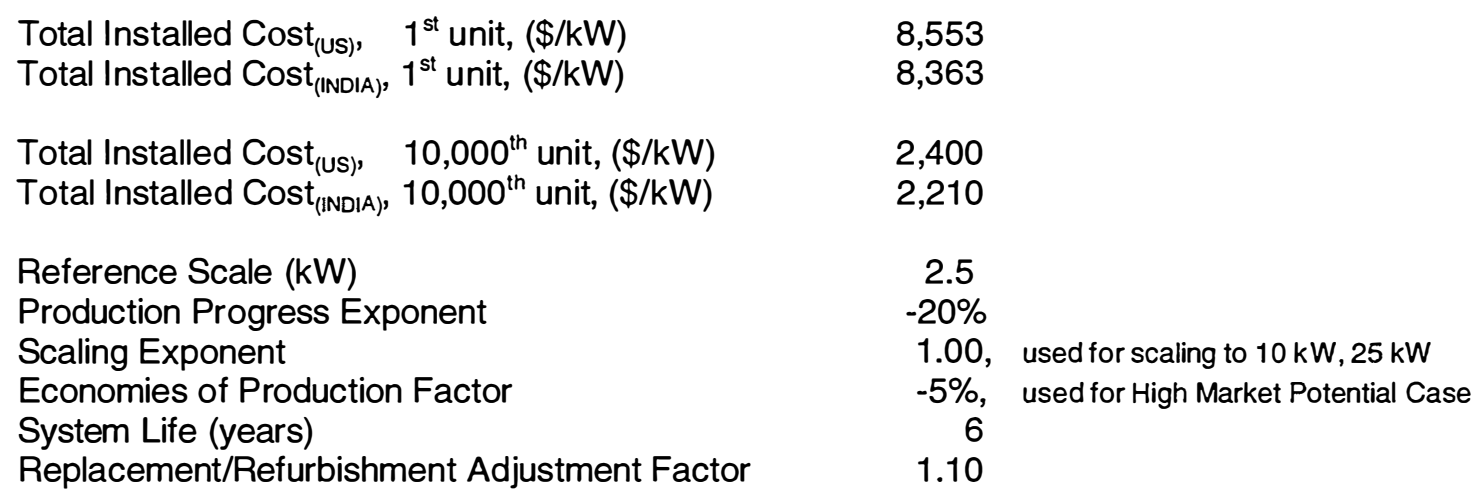

At the time of this report, there were insufficient data to determine precise O\&M costs (excluding fuel costs) for these systems from the developers. However, costs for operating labor and materials have been estimated based on limited information provided by Sunpower Inc. for its free-piston engine. A total O\&M cost of approximately $\$ 0.035 / \mathrm{kWh}$ excluding fuel for a $2.5 \mathrm{~kW}$ engine was estimated to consist of $80 \%{ }^{91}$ labor costs and $20 \%$ materials costs. This high ratio assumes that servicing these engines would be synonymous to servicing similarly sized internal combustion or diesel units.

\section{Exhibit 7.6-2 \\ Operating Cost Assumption Summary-Stirling Engine}

$\begin{array}{llr}\text { Total O\&M } & & \\ \text { Total O\& Costs (mils/kWh) } & & 35.0 \\ \text { Total O\&M } & 7.0 \\ \text { Tus) Laterials (mils/kWh) } & = & 7.0 \text { Labor (mils/kWh) } \\ \text { Total O\&M } & = & 28.0 \\ \text { Total O\&M } & = & 0.1 \\ & = & 7.1\end{array}$

\footnotetext{
${ }^{90}$ Stirling Thermal Motors, October 1996.

${ }^{91}$ Based on similar experiences with diesel generators.
} 
Power Output Performance and Related System Efficiencies. Estimates for power output for these systems currently stretch over a range of approximately $1 \mathrm{~kW}$ to $75 \mathrm{~kW}$. Single engine systems at the high end of this range remain to be demonstrated. Efficiencies for this system also vary over a large range. Sunpower has recently completed tests with its $2.5-\mathrm{kW}$ prototypes, which suggest that engine efficiencies might be in the $28 \%$ (lower heating value [LHV]) range. However, overall power plant efficiency (taking into account combustion and gasification efficiencies) may be nearer to $20 \%$, roughly equivalent to efficiencies for similarly sized diesel engines. Higher efficiencies have been suggested for this technology, and estimates that approach $40 \%$ for the engine are not uncommon. We assumed that biomass-powered Stirling engines will be able to achieve the overall efficiencies demonstrated by Sunpower, or about $20 \%$.

\section{Exhibit 7.6-3}

\section{Performance Assumption Summary-Stirling Engine}

$\begin{array}{lc}\text { Reference Plant Size (kWs) } & 2.5 \\ \text { Net Plant Heat Rate (Btu/kWh) } & 17,060 \\ \text { Net Plant Efficiency HHV } & 20 \% \\ \text { Capacity Factor } & 80 \%\end{array}$

\subsubsection{Direct-Fired Combustion Turbines}

Capital Costs. Capital costs for direct fire combustion turbines are indicative of the additional fuel handling and turbine modifications required to make the system function efficiently. Although typical simple-cycle gas turbine plants may range in capital costs of $\$ 400-\$ 500 / \mathrm{kW},{ }^{92}$ the BIOTEN facility cost about $\$ 1,250 / \mathrm{kW} .{ }^{93}$ This system is certain to benefit from the knowledge gained during operation of the demonstration plant, which may provide some insight into ways of reducing the necessary investment. Additionally, although these systems are not expected to drive large power projects in the short term, the use of somewhat more efficient and larger gas turbines may provide some economies of scale. On a $\$ / \mathrm{kW}$ basis, these systems may also benefit from use in combined cycle or cogeneration applications.

Most equipment and plant systems for this technology represent the application of commercially available technology. Much of the equipment used in the facility is purchased from outside vendors, then modified for plant use. Orders for major components (such as the gas turbine, pulverizers, or buildings) placed as a result of constructing these plants will probably not be of sufficient magnitude to represent cost saving to the individual component manufacturers, but some savings may be passed on to project developers through bulk purchase discounts associated with multiple orders. Therefore, no economies of manufacture or production progress cost reductions have been attributed to manufacture of the equipment. However, some cost reductions will probably occur from system optimization. These improvements might include more optimum sizing of equipment to match individual subsystem flows and other modifications to the plant that would improve overall efficiency. For this reason a small amount of production progress was indicated on the estimated equipment portion (2\% reduction in costs for every doubling of the number of facilities built). Similarly, unless these systems demonstrate the viable use of feedstocks other than sawdust, and fuel processing equipment can be upgraded to handle larger throughput, it may be difficult for these systems to be dramatically scaled up and experience some of the real benefits of economies of scale. However, a small scaleup factor was used based on the limited information available. A graphical analysis of data presented in the 1996 Gas

\footnotetext{
${ }^{92}$ Gas Turbine World Handbook, 1996, vol.17, Pequot Publications.

${ }^{93}$ BIOTEN, 1996, Site Tour: Commercialization Demonstration Plant, Red Boiling Springs, TN, September 19-20.
} 
Turbine World Handbook $k^{94}$ is presented in the Appendix, but a summary can be found in Exhibit 7.6-4. Correction for market influences or the manufacturers' costs were not made, and this information is intended only to provide some means of adjusting plant costs to reflect the apparent reductions associated with using larger gas turbines. Further, as this factor is applied to the entire plant costs, all other equipment is estimated to experience approximately the same level of scaling.

Exhibit 7.6-4

Average Costs and Efficiencies of Small Gas Turbines

\begin{tabular}{|c|c|c|}
\hline Plant Size & $\begin{array}{c}\text { Avg. } \\
\text { LHV } \\
\text { Efficiency }\end{array}$ & $\begin{array}{c}\text { Avg. } \\
\text { Price (\$/kW) }\end{array}$ \\
\hline Less than $5.0 \mathrm{MW}$ & $25.7 \%$ & 583 \\
\hline Greater than or equal to 5 , less than $10 \mathrm{MW}$ & $30.7 \%$ & 416 \\
\hline Greater than or equal to 10 , less than $20 \mathrm{MW}$ & $32.7 \%$ & 426 \\
\hline
\end{tabular}

Exhibit 7.6-5

Capital Cost Assumption Summary-Direct-Fired Combustion Turbine

Total Installed Cost $_{(\text {us) }}, 1^{\text {st }}$ unit, $(\$ / \mathrm{kW})$

Total Installed Cost (INDIA), $1^{\text {st }}$ unit, $(\$ / k W)$

Total Installed Cost $\left(\right.$ US), $10,000^{\text {th }}$ unit, $(\$ / \mathrm{kW})$

Total Installed Cost (INDIA) $, 10,000^{\text {th }}$ unit, $(\$ / \mathrm{kW})$

Reference Scale $(\mathrm{kW})$

Production Progress Exponent

Scaling Exponent

Economies of Production Factor

System Life (years)

Replacement/Refurbishment Adjustment Factor
1,250

1,089

1,067

906

5,800

$-2 \%$

0.85 , used for scaling to $10 \mathrm{MW}, 20 \mathrm{MW}$

$-5 \%$, used for High Market Potential Case 30

NA

O\&M Issues. Many O\&M issues unique to these systems stem directly from material handling. For example, the commercial equipment originally planned by BIOTEN to remove large pieces of bark or nonwood material was not sufficient to guarantee a $100 \%$ trash-free feed to the pulverizing units. Introducing this tramp material to this part of the system would be disastrous, so BIOTEN engineers had to design an additional separation process that would positively remove all potentially damaging materials. Although the system did impose some limits on the fuel feed rate to the pulverizers, this does not suggest that all differences between the BIOTEN facility and more conventional simple-cycle natural gas-fueled generation are detrimental. For example, provided there is a market for it, bark separated from the fuel stream can be combined with wood ash and sold as fertilizer. Other material handling issues presenting challenges include fuel stream moisture contents (incoming fuel is being dried using turbine exhaust), particle size (processed to sizes smaller than 1200 microns using air-swept pulverizers), and fuel dust injection and control (important to ensure that hot gases

\footnotetext{
${ }^{94}$ Gas Turbine World Handbook, vol. 17, 1996, Pequot Publishing.

${ }^{95}$ Gas Turbine World Handbook, vol. 17, 1996, Pequot Publishing.
} 
do not back into the charge vessels and ignite incoming fuel). These have been addressed sufficiently to allow for commercial demonstration.

Specific emissions information regarding direct-fired combustion turbines was unavailable at the time of this report. However, additives and gas bypasses were employed in the BIOTEN design to decrease $\mathrm{NO}_{\mathrm{x}}$ and $\mathrm{CO}$ emissions. In addition, current noise levels of $70 \mathrm{db}$ at the property line will probably be sufficiently abated by mufflers and silencers. Whether other control measures will be required (especially with regards to the combustion of other types of feedstock, but in lieu of additional test data and modifications) is unclear. This analysis assumes that these problems will be overcome.

Once testing and optimization are complete, manpower requirements for the plant are expected to be minimal. Only two operators will be required on each shift and one plant manager will be needed. ${ }^{96}$ As estimated by BIOTEN, O\&M costs (excluding fuel) for the 5-MW plant are expected to be $\$ 330,000 / \mathrm{yr}$ for operations, and $\$ 280,000 / \mathrm{yr}$ for maintenance, yielding a total cost of $\$ 610,000 / \mathrm{yr}$ or $\$ 1.40 / \mathrm{kWh}$. Based on the number of operators and an average O\&M labor rate a 60:40 split between labor and materials was calculated and used in separating the O\&M costs. For a more detailed explanation of costs refer to the Appendix.

\section{Exhibit 7.6-6}

Operating Cost Assumption Summary-Direct-Fired Combustion Turbine

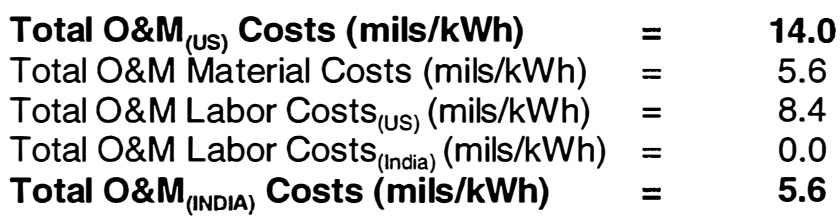

Power Output Performance and Related System Efficiencies. Test data recently obtained from the BIOTEN unit suggest that a net power output of $6 \mathrm{MW}$ may be obtainable. The current net plant heat rate is estimated to be approximately $14,800 \mathrm{Btu} / \mathrm{kWh}$ corresponding to a plant thermal efficiency of $23 \%$. As mentioned previously, modifications in the plant are expected to result in greater efficiencies and reduce the heat rate to approximately $13,500 \mathrm{Btu} / \mathrm{kWh}$. A summary of the performance parameters used in this analysis follows.

\section{Exhibit 7.6-7}

Performance Assumption Summary-Direct-Fired Combustion Turbine

$\begin{array}{lr}\text { Reference Plant Size (kW) } & 5,800 \\ \text { Net Plant Heat Rate (Btu/kWh) } & 13,500 \\ \text { Net Plant Efficiency HHV } & 25 \% \\ \text { Capacity Factor } & 80 \%\end{array}$

\subsubsection{Fuel Cells}

Capital Costs. Capital cost estimates for natural gas fuel cells range between $\$ 1,200$ and $\$ 3,000 / \mathrm{kW}$ depending on the type of fuel cell and other assumptions used in the calculation. For a biomass-fueled system, estimates would also need to include costs for fuel handling and gasification infrastructure. We assumed that the first

\footnotetext{
${ }^{96}$ Preliminary estimates based on discussions with BIOTEN personnel
} 
commercial natural gas MCFCs will require capital investments of $\$ 2,655 / \mathrm{kW} .{ }^{97}$ Production progress for fuel cells is difficult to estimate, in that there is no obvious model to draw on for comparison. However, some developers believe that a limited production run of perhaps 40 to 50 units could reduce the costs of MCFC units to $\$ 1,200 / \mathrm{kW}$ or $\$ 1,300 / \mathrm{kW}$.

Fuel cell power units are extremely modular in nature, and future units will probably be available in only a few, carefully selected power ratings. Larger plants will be constructed by coupling a number of smaller units together. Therefore, economies of scale will probably be less significant than either economies of production or improvements in the base technologies themselves. In that respect, although some smaller PAFC systems could be considered commercial, the larger MCFC and SOFC systems are still in the demonstration phase. Advancements in the technologies may therefore still afford large cost reductions and efficiency improvements beyond those forecast in this analysis.

As mentioned previously, fuel gasification and biomass handling equipment will also be required. Like the fuel cells, cost estimates for these systems vary greatly depending on the manufacturer, unit size, and production economies. For this report, gasification cost and performance data will be based on available estimates for a low pressure, indirect gasification system such as the one currently undergoing testing by Battelle Columbus Laboratories (BCL).

As with the Stirling systems, there is an additional item to consider with respect to the capital investments in fuel cell-system life. Although a great deal of research and improvement are being made in this area, these units are likely to suffer from a deterioration in stack voltage that will ultimately require that the stacks be replaced. A capital adjustment factor such as like the one described in section 7.6-1, is applied in the COE analysis to account for future replacement costs. The adjustment is applied only to the cost of the fuel cell and system life is assumed to be 40,000 hours. Estimates for these replacement and refurbishment costs were based on available data from one developer and have been estimated to be a little more than $11 \%$ of the original installed costs in India.

O\&M Issues. Recent demonstration and pilot plant information on fuel cells throughout the world have provided critical information on some of their operational advantages and disadvantages. Of most notable interest is the environmental profile of fuel-cell based generation. Emission levels of $\mathrm{SO}_{\mathrm{x}}$ are essentially negligible, primarily because the sensitivity of fuel cells to sulfur requires incoming fuel to be nearly sulfurfree. $\mathrm{NO}_{\mathrm{x}}$ emissions can be more than 100 times lower than some combined cycle plants, and $\mathrm{CO}_{2}$ levels are also extremely low relative to fossil-fired generation. In addition, these units are typically characterized by low noise levels (one developer estimates 60 decibels at $100 \mathrm{feet}^{98}$ and small footprints, which allow for extremely flexible siting.

\section{Exhibit 7.6-8 \\ Capital Cost Assumption Summary-Fuel Cell}

\begin{tabular}{|c|c|}
\hline $\begin{array}{l}\text { Total Installed Cost } \\
\text { Total } \\
\text { Total Installed } \text { Cost }_{(\text {INDIA) }}\end{array}$ & $\begin{array}{l}1^{\text {st }} \text { unit, }(\$ / \mathrm{kW}) \\
1^{\text {st }} \text { unit, }(\$ / \mathrm{kW})\end{array}$ \\
\hline $\begin{array}{l}\text { al Installed Cost } \\
\text { al Ins), }\end{array}$ & $\begin{array}{l}10,000^{\text {th }} \text { un } \\
10,000^{\text {th }} \text { un }\end{array}$ \\
\hline
\end{tabular}

\footnotetext{
${ }^{97}$ Energy Research Corporation (ERC), October 1996.

${ }^{98}$ Fuel Cell Engineering, The Mk $2 K$-SS DFC Power Plant.
} 
Reference Scale $(\mathrm{kW})$

Production Progress Exponent

Scaling Exponent

MW

Economies of Production Factor

Case

System Life (years)

Replacement/Refurbishment Adjustment Factor
2,400

$-25 \%$, based on assumed similarity to airplane production

0.98, used for scaling to $6 \mathrm{MW}, 10$

$-5 \%$, used for High Market Potential

6

1.075

O\&M costs for fuel cells (excluding fuel) are relatively low. For smaller, natural gas fuel cells, only a single operator may be required per shift, and operational monitoring can in fact be handled remotely. Maintenance for these systems is expected to be restricted to balance-of-plant equipment such as blowers, filters, water and gas cleanup systems, etc., and plant availability may be more than $90 \%$.

Unfortunately, the required gasification and fuel handling components of a biomass-based system increase the complexity of the facility O\&M. Most notably, siting the facility is made more difficult because of the need to obtain and maintain additional space for a solid fuel storage facility and biomass receiving/processing equipment. Operating of the gasification plant and infrastructure may require as much, if not more, monitoring than the power generation portion of the plant. For this report, O\&M costs (excluding fuel) for a U.S.-based plant are estimated to be about $\$ 0.024 / \mathrm{kWh}$.

\section{Exhibit 7.6-9 \\ Operating Cost Assumption Summary-Fuel Cell}

\begin{tabular}{|c|c|}
\hline O\&M $M_{(u s)}$ Costs (mils/kWh) & $=$ \\
\hline Total O\&M Material Costs (mils/kWh) & $=$ \\
\hline Total O\&M Labor Costs $($ US $)$ (mils/kWh) & $=$ \\
\hline Total O\&M Labor Costs (India) $_{(\text {mils/kWh) }}$ & $=$ \\
\hline Total O\&M $M_{(\mathrm{INDIA})}$ Costs (mils/kWh) & 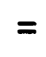 \\
\hline
\end{tabular}

Power Output Performance and Related System Efficiencies. Fuel cells have the distinct advantage of being easily coupled to form a large variety of power plant sizes. However, this modularity does not equate to large plant efficiency gains and the specifications of one individual unit are expected to reflect the performance of a large variety of plant sizes. For this analysis, the performance characteristics of Fuel Cell Engineering Corporation's (FCE) direct fuel cell (DFC) have been used to estimate the plant characteristics of biomass fuel cell. For this report, power output for the natural gas-fueled system is rated at $2.40 \mathrm{MW}$, with a net plant heat rate of 6,350 (LHV) Btu/kWh. Plant availability for these systems should exceed $90 \%$. However, for a biomass-powered plant one would expect availability to be reduced somewhat. For this report a capacity factor of $80 \%$ has been used. For a biomass system, plant availability and gross output are assumed to remain constant. However, because of inefficiencies and the losses associated with gasification and fuel handling (assumed to be $77 \%$ [HHV] efficient), plant efficiency has been reduced to approximately $37 \%$ on HHV.

Exhibit 7.6-10

\section{Performance Assumption Summary-Fuel Cell}

Reference Plant Size $(\mathrm{kW})$

Net Plant Heat Rate (Btu/kWh)

Net Plant Efficiency HHV

Capacity Factor
2,400

9,148

$37.3 \%$

$80 \%$ 


\subsubsection{Biomass Integrated Gasification Combined Cycles}

Capital Costs. Initial capital costs for BIGCC systems are estimated to lie in a wide range of $\$ 1,100$ to $\$ 3,000 / \mathrm{kW}$, but are highly dependent on system specifics. For example, some estimates for gasification facilities may vary by at least a factor of three depending on the type and cost of the individual plants. ${ }^{99}$ Because the gasification plant can represent more than one-third of the total plant costs, estimates for this cost have a significant impact on the total investment and the resulting COEs, and different gasifiers can have significantly different costs.

For this report, TPCs are assumed to be $\$ 1,307 / \mathrm{kW}$ to construct a BIGCC plant that uses an indirect gasification plant in the United States. A BCL gasifier would represent approximately $50 \%$ of the overall cost, or approximately $\$ 618 / \mathrm{kW} .{ }^{100}$ This cost would include a boost compressor, which would be necessary to deliver product gas to the gas turbine.

Detailed estimates for a first plant cost of this system were not available, but a number of Nth plant costs have been proposed. Even these costs, for similar systems vary greatly. As an example, a similar system at less than half the capacity was quoted at more than $20 \%$ less than the Nth plant costs quoted above $(\$ 1,307 / \mathrm{kW})$. The difference in costs is even more significant if one considers that the larger plant should exhibit some economies of scale. For this reason, the costs presented in this report represent (even though they are actually Nth plant costs) are used as a first plant cost. However, only the gasification plant is assumed to benefit from manufacturing economies, and all other equipment is assumed to be commercially available and is not forecast to experience cost reductions.

Gas turbines and gasification plants will probably benefit from economies of scale, although much of the benefit will depend on equipment selection. Unlike the other technologies discussed, the reference scale of this system probably represents the extreme upper limit of such a system because of resource and technology restrictions. Economies of scale would therefore increase the unit costs of the systems modeled in this report. Using the data collected for Exhibit 7.2-4, a graphical analysis of information presented in the 1996 Gas Turbine World Handbook indicates that natural gas combined cycle plants exhibit some type of economy of scale. Although the inconsistent nature of the data source limits the conclusions, there is a noticeable trend of decreasing cost with increasing plant size. For this report, an average value of scale factors that appeared indicative of the trend (0.82) is used to determine the TPCs for 20,40, and $80 \mathrm{MW}$.

O\&M Issues. Except for the gasification plant, O\&M of a BIGCC system is expected to resemble the requirements of a similarly sized natural gas-fired combined cycle plant. In general, gas turbines have a reputation of high reliability and maintainability, and BIGCC plants are not expected to be burdened with large overhead or staffing requirements. However, the gasification plant associated with BIGCC systems will increase plant complexity and therefore add to the O\&M costs relative to a natural gas-fired plant. Further, some gasification systems have significantly higher maintenance costs than others and $\mathrm{SO}_{\mathrm{x}}$ emissions for the gasification plants are expected to exceed those of their coal-fueled brethren. Combustion of biomass synthesis gas is also a concem in areas with especially strict $\mathrm{NO}_{\mathrm{x}}$ emission requirements. A number of filtration and catalytic processes are being studied to address this issue.

For this report O\&M costs were estimated based on cost estimates for operating the BIGCC system using an indirect gasification system such as the one discussed in section 6.4. O\&M costs for a system that operates in the United States, excluding fuel, are expected to be approximately $\$ 0.0115 / \mathrm{kWh}$.

\footnotetext{
${ }^{99}$ Craig, K.R. and M.K. Mann, 1993, Cost and Performance Analysis of Biomass-based Integrated Gasification Combined Cycle Power Systems, December.

${ }^{100}$ Craig, K.R. and M.K. Mann, 1993, December.
} 


\section{Exhibit 7.6-11 \\ Capital Cost Assumption Summary-BIGCC}

\begin{tabular}{|c|c|}
\hline 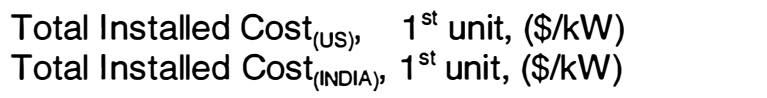 & $\begin{array}{l}1,307 \\
1,138\end{array}$ \\
\hline 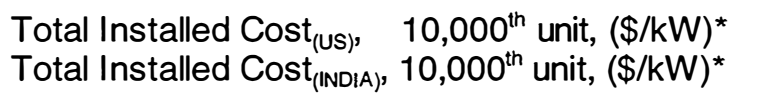 & $\begin{array}{l}990 \\
821\end{array}$ \\
\hline $\begin{array}{l}\text { Reference Scale }(\mathrm{kW}) \\
\text { Production Progress Exponent }\end{array}$ & $\begin{array}{l}122,000 \\
-20 \%\end{array}$ \\
\hline $\begin{array}{l}\text { Scaling Exponent } \\
\text { Economies of Production Factor } \\
\text { System Life (years) } \\
\text { Replacement/Refurbishment Adjustment Factor }\end{array}$ & $\begin{array}{l}0.82 \text {, used for scaling to } 20 \mathrm{MW}, 40 \mathrm{MW}, 80 \mathrm{MW} \\
-5 \% \text {, used for High Market Potential Case } \\
30 \\
\text { NA }\end{array}$ \\
\hline
\end{tabular}

*Installing $10,000 \mathrm{BIGCC}$ units is unlikely in the next 20 years. This figure is presented only as a benchmark to compare eventual cost reductions of this technology to the others examined. Market penetration in this report varies from 8 to 91 units of various sizes between now and 2020.

\section{Exhibit 7.6-12 \\ Operating Cost Assumption Summary-BIGCC}

\begin{tabular}{|c|c|c|}
\hline Total O\&M $M_{\text {(us) }}$ Costs (mils/kWh) & $=$ & 11.5 \\
\hline Total O\&M Material Costs (mils/kWh) & $=$ & 6.9 \\
\hline Total O\&M Labor Costs (us) $_{\text {(mils/kWh) }}$ & $=$ & 4.6 \\
\hline Total O\&M Labor Costs (India) $(\mathrm{mils} / \mathrm{kWh})$ & $=$ & 0.0 \\
\hline Total O\&M $M_{(\mathbb{N D | A})}$ Costs (mils/kWh) & $=$ & 6.9 \\
\hline
\end{tabular}

Power Output Performance and Related System Efficiencies. Power output for the systems modeled in this report will range from $20 \mathrm{MW}$ to $80 \mathrm{MW}$. The lower bound is based on the assumption that the economics for plants that use gas turbines smaller than 13 or $14 \mathrm{MW}$ will suffer from lack of efficiency and relatively high costs. The upper limit for using BIGCC in DG applications will be availability of biomass resource and the power requirements of the end users. Plants of about $80 \mathrm{MW}$ are not suitable for small commercial or village power requirements. More likely targets are industrial endusers with available resource and handling infrastructure (such as pulp and paper mills), grid stabilization, or mini-grid applications.

Like other combined cycle plants, plant efficiencies for BIGCCs can be expected to be quite high. In some cases they will approach $40 \%$ on an HHV basis. For this study, a nominal plant heat rate of 9,638 (HHV) $\mathrm{Btu} / \mathrm{kWh}$ has been used to calculate plant performance. This encompasses all plant efficiencies, including those associated with gasification.

\section{Exhibit 7.6-13}

\section{Performance Assumption Summary-BIGCC}

Reference Plant Size (kW)

Net Plant Heat Rate (Btu/kWh)

Net Plant Efficiency HHV

Capacity Factor
122,000

9,638

$35.4 \%$

$80 \%$ 


\subsection{Assumptions Used in Coal Plant Analysis}

The specifications used to analyze of the coal plant are summarized as part of Exhibit 7.7-1. The costs were calculated using EPRI TAG methodology with the exception of labor costs (construction and O\&M) which were adjusted for Indian labor rates according to the methodologies previously outlined for the DG systems. Transmission and theft costs were added to the calculated busbar COE as described in section 7.5. Fuel costs for the coal plant are based on country averages. Specific calculations for all costs used in this analysis are in the Appendix.

Exhibit 7.7-1

Summary of Assumptions for Coal-Fired Plant

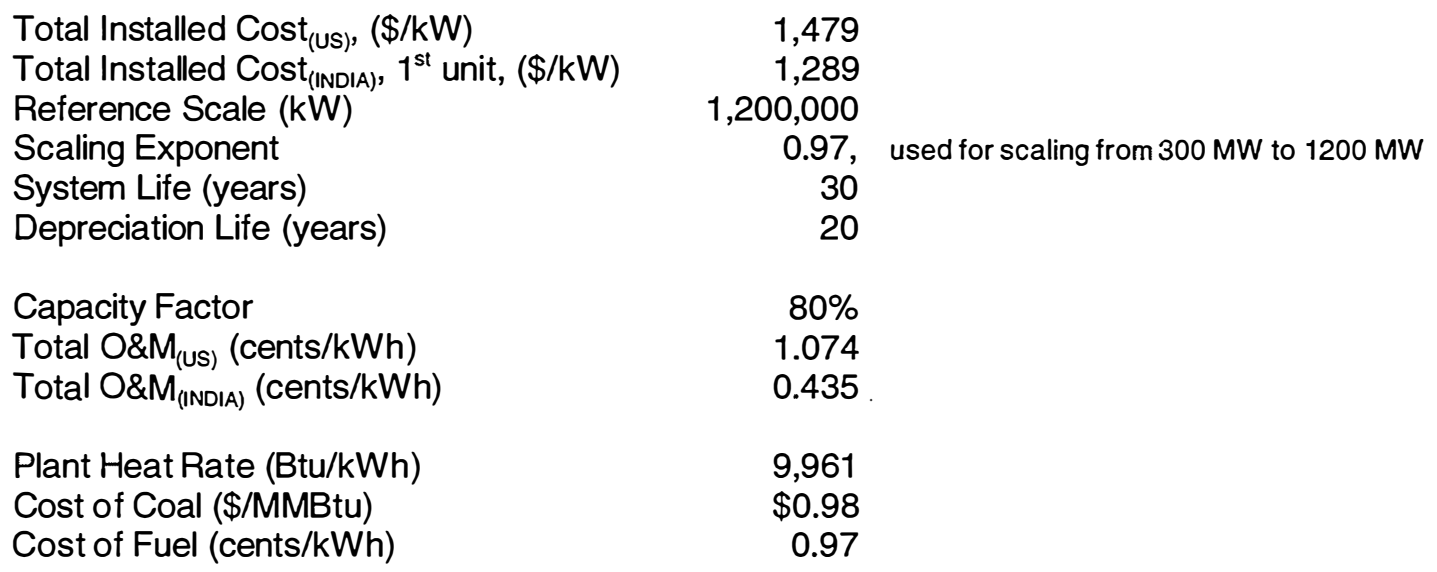

\subsection{Results of COE Comparison}

Figures 7.8-1,2,3, and 4 represent a condensation of the sensitivity analyses performed. Each summary graph demonstrates the entire range of results (based on sensitivities of fuel price, production progress cost reductions, scale, and market penetration) for an individual technology as well as the results of the coal plant analysis. The vertical axis for all graphs is presented in cents/kWh. The two independent horizontal scales allow the results of the different analyses to be overlaid. The COEs for the coal plant are read using the second horizontal axis $(\mathrm{km})$ and $\mathrm{COE}$ results for each of the biomass technologies are read using the first horizontal axis (Yr). Overlaying the results in this manner allows for a rough determination of when, and at what distance from the grid these technologies may generate electricity at prices competitive with central grid power.

The electricity costs represented for the 1,200-MW coal plant represent the likely upper and lower bounds (the best and worst cases) of central grid provided power. In the worst case, we assumed that a new plant is to be built to supply power to a num-ber of rural areas. The COEs reflect the high capital amortization costs and associated transmission costs over the distances shown. The best case represents the production costs of a stateowned, fully depreciated coal plant (no capital recovery char- ges) that is undergoing grid exten- sion to supply new customers. The cost of the actual extension is as- sumed to be the same as that fore-casted for the new plant. 
Exhibit 7.8-1

The results of the analysis for future prospects of implementing biomasspowered DG were favorable. However, a few comments should be made with respect to the magnitude of the COEs that were calculated. First, these are the busbar COEs plus transmission costs (applicable to the coal plant only). The actual delivered COEs would also include a distribution cost (refer to section 7.5). Second, extremely low labor rates and a fuel cost of less than $\$ 1.00 / \mathrm{MMBtu} \cdot$ ensure that electricity generated at these large-scale coalfired plants will remain competitively priced in India. However, as estimated in this report, transmission costs represent a sig- nificant investment, and avoiding these costs has great value to the Indian power consumer.

If the cost reductions projected for the biomass technologies are obtainable, all appear as though they will be able to generate electricity at costs competitive with those of a new coal power station between now and the end of the century. However, even more encouraging are the predictions that all these technologies may be competitive with even the best coal case between now and the end of the next decade. Of the four technologies examined, direct-fired combustion turbines and BIGCCs demonstrated the potential to be extremely competitive with coal-fired power almost immediately. In fact, by late in the next decade, even at the upper cost band, direct-fired CTs may be a lower cost alter- native than grid extensions from fully amortized coal plants at transmission line lengths greater than $200 \mathrm{~km}$. A similar conclusion can be drawn for the BIGCC case.

Exhibit 7.8-2

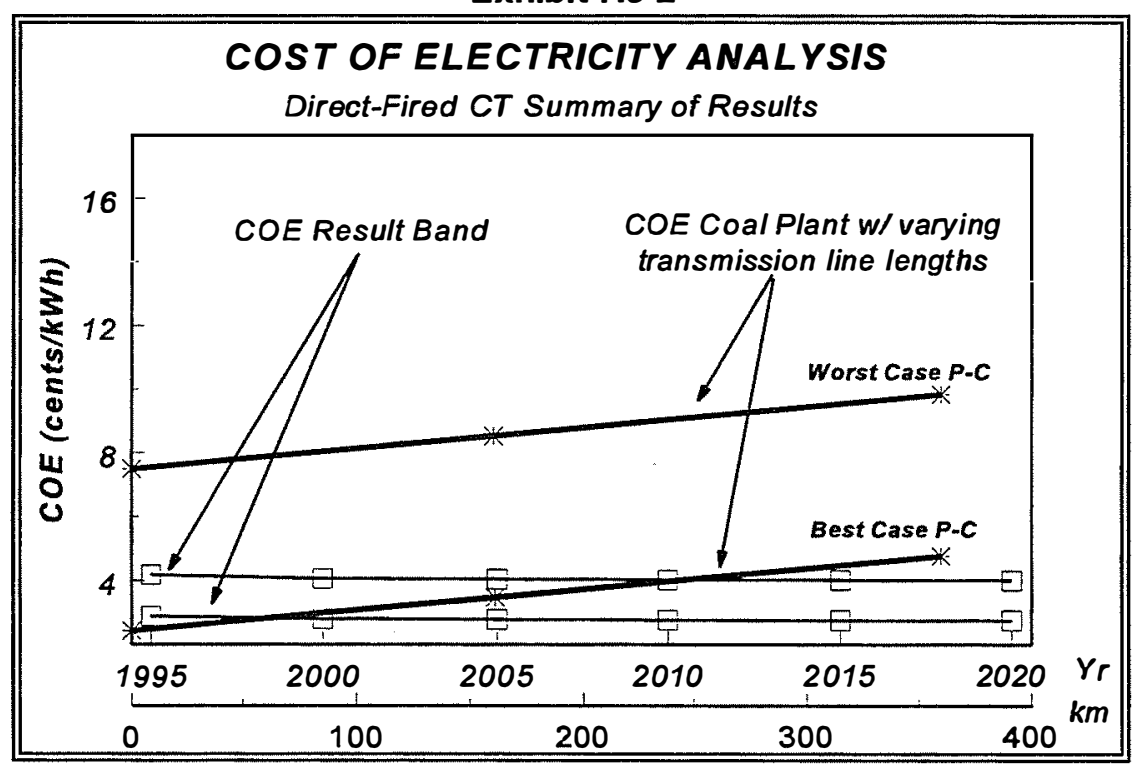

Both technologies will probably be aimed at either industrial users or at larger, captive loads establishments. A more detailed case study would be required, but the costs estimated in this analysis suggest that selling excess power back to the grid may be profitable.

Undoubtedly, the Stirling engine versus coal fired generation analysis represented the most one-sided of the case comparisons. However, relative to the new coal plants' COEs, these could apparently be pursued as an economical DG technology if enough production progress can be realized. By 
Exhibit 7.8-3

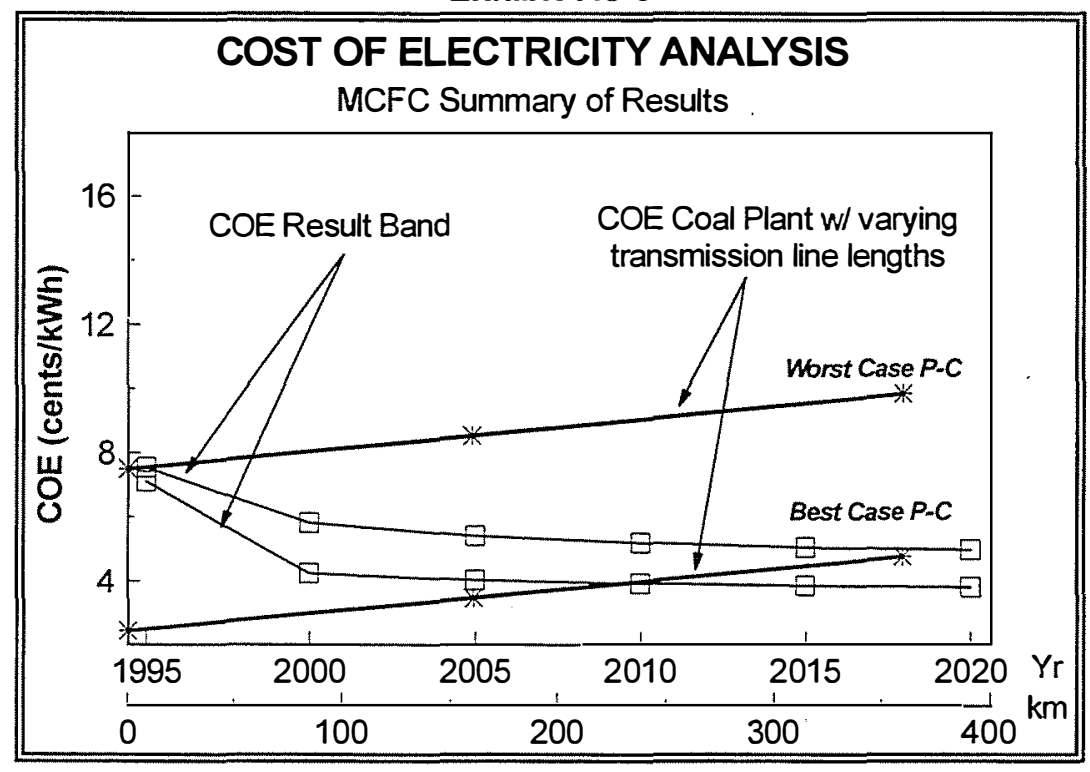

approximately 2010 , this technology may eventually even be competitive to the best coal case. Stirling engines also have several advantages that are difficult to quantify. These systems fill a niche in scale that differs from the other technologies examined and they are the only truly skid-mounted systems examined, even with the biomass combustor. This type of system will most likely find its niche in providing power to more remote areas where grid extension is not an option, where electricity will not be available, or is not planned for several years. Of course they will experience substantive competition from more established technologies such as

fossil fuel-powered gensets. However, in a comparative study performed by Sunpower Inc., a diesel powered genset ( $\$ 1.20 /$ gal fuel), has a COE nearly three times that of a future Stirling engine operating on wood at a fuel cost of $\$ 20 /$ ton. If this ratio remains reasonably constant in India, the probability of biomass-powered Stirling engines breaking into the market seems high. Addition- ally, acceptance of a small rural biomasspowered system may be more likely in a country that readily accepts the use of biomass waste materials for everyday energy use. The marketing advantage of familiarity that most attribute to fossil gensets (small dieseland gasoline-powered generators, for example) may not be significant in the overseas market. Lastly, although complete information was not available at the time of this report, it has been suggested that STM's 25-kW system may have materially lower capital investment cost and higher efficiency than those presented here for Stirling engines. If true, during the next 4 to 5 years, these systems could provide the power at a cost that is competitive and well sized to meet the needs of the smaller electricity loads.

As with all the technologies modeled, under the conditions of this analysis MCFC plants may be able to compete with new coal-powered generation in the short term. In the longer term, expected cost reductions and improvements in efficiencies (not projected) will ensure that they will be competitive to even less expensive power. Complete market penetration may occur after 2010, but even the first units may be able to find situations suitable to their economic application.

All these may benefit from another means of obtaining additional cost savings, especially those that require the construction of new manufacturing facilities. India has an abundance of inexpensive, skilled labor. If the cost reductions forecasted for constructing these plants were also applied to some of the plants manufacturing major components, additional cost savings could be realized. A detailed cost sensitivity analysis of this point was not performed because identifying the exact proportion of the installed plant costs of these technologies that are due specifically to manufacturing labor is difficult. However, if we estimate that the cost of the 10,000 th Stirling system (costing $\$ 2,210 / \mathrm{kW}$ if manufactured elsewhere, and constructed in India) could be reduced by $\$ 400 / \mathrm{kW}$ due to differences in manufacturing labor costs, the COEs could be reduced by another $5 \mathrm{mils} / \mathrm{kWh}$. Locating manufacturing facilities in India may also be a staging point for penetration into other, equally lucrative markets in Asia. 
Exhibit 7.8-4

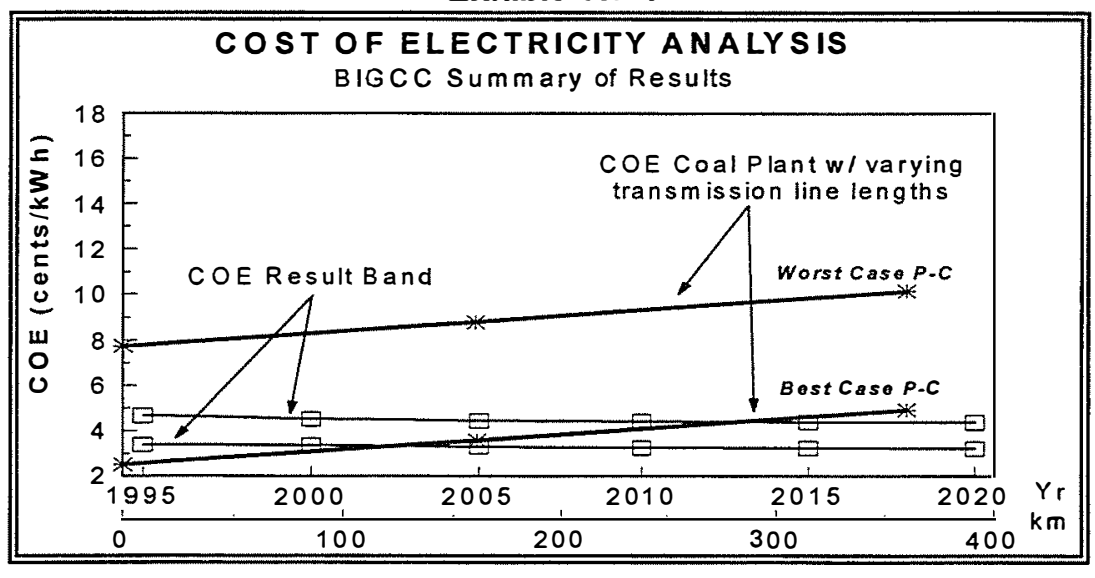




\subsection{Conclusion}

A variety of issues affect India's rural electricity demand, including economic development, power reliability, a long-standing history of heavily subsidized agricultural electricity rates, and environmental concerns. DG systems may represent one way of addressing many of these issues. Although many of the forecasted increases in electricity demand will probably be met by grid extension, there are rural communities in areas where grid extension is uneconomical or technically impractical. DG systems may improve the reliability of India's electricity infrastructure. Increased reliability can stimulate job creation and improve productivity, improve the quality of life, and help reduce agricultural subsidies that will strengthen the SEBs. DG systems offer location and planning flexibility, cost savings by avoiding T\&D losses, and the economic benefits associated with manufacturing the technologies in-country. Biomass-powered DG systems may offer additional environmental benefits, rural familiarity with the resource, and the possibility of a diversified agricultural economy.

The results of the COE comparison between the studied biomass DG systems and the coal-fired central grid station were encouraging. If the cost information collected represents the actual costs for these technologies and these systems are reliable and maintainable, they are well positioned to begin to penetrate India's electricity market by the end of the decade. However, the greatest barrier to implementing these technologies in the rural communities may not be technical or economic. Competing uses for land may limit the development of biomass energy crops, and a cultural desire to use nearly all waste material for purposes other than generating electricity may slow the pace of power projects larger than 100-200 kW. To that end, the smaller DG technologies examined (fuel cells and Stirling engines) may be better suited to initial biomass related projects in rural areas. Larger technologies are more likely to be used to meet the needs of dedicated industrial customers with available biomass feedstocks (most likely bagasse). These plants may find the SEBs willing to buy and sell any excess power provided, but directly selling to rural agricultural customers is not likely in the near term.

The results of this report suggest that future work regarding biomass DG technologies in India is warranted and should concentrate on exploring the costs of providing DG power more closely. Load profiles, industrial, commercial, and residential case studies will increase industries' understanding of the complexities associated with developing international markets. Such an effort would also be eminently useful in further refining likely first markets for these systems and provide invaluable information to manufacturers and project developers.

In general, biomass-powered DG systems may offer a unique opportunity to increase the global significance of biomass generation. They may first appear in niche markets where their economic, environmental, and potential for competitive electricity production costs can be fully realized. Later, as system costs are reduced and operating experience is gained, these systems may begin providing power to a market dominated by larger, coal-fired generation. India's current governmental policies, low labor costs, and unique market niches may provide an opportunity for biomass power project developers to gain much-needed market share and acceptance. 


\subsection{References}

Antares Group, Inc., 1996, Global Repowering Opportunities for Biomass Power, prepared for USDOE National Renewable Energy Laboratory.

BIOTEN, 1996, Site Tour: Commercialization Demonstration Plant, Red Boiling Springs, TN, Spetember 1920.

Craig, K.R. and M.K. Mann, 1993, Cost and Performance Analysis of Biomass-Based Integrated Gasification Combined Cycle (BIGCC) Power Systems, NREL Completion Report, December (revised January 1996).

De Jong, J.R., 1964, "Increasing Skill and Reduction of Work Time-Concluded," Time and Motion Study, October, pp.20-33.

Detweiler, John H., 1995, “A Note on an Asymptotic Learning Curve,” The Journal of Cost Analysis, Spring, pp. 21-39.

D’Monte, D., 1996, “Tamil Nadu Outfit Consulting on Biomass-Fired Cogen Plants," The Solar Letter, vol.6, no.11, May 10, p.179.

DRI/McGraw Hill, 1996, The Future of the Electric Power Industry.

Electric Power Research Institute, 1993, TAG-Technical Assessment Guide, vol.1: rev.7, June.

Energy Research Corporation (ERC), 1996, personal communication, October.

Flavin, Christopher and Nicholas Lenssen, WorldWatch Institute, 1994, Power Surge: Guide to the Coming Energy Revolution, W.W. Norton \& Company: New York.

Fuel Cell Commercialization Group, 1996, System Planning Workbook, Washington, DC.

Fuel Cell Engineering Corporation, “The Mk 2K-SS DFC Power Plant,” Washington, DC.

Gas Turbine World Handbook, vol.17, 1996, Pequot Publishing.

Government of India (GOI), 8th Five Year Plan, Power Section, New Delhi.

GOI, Ministry of Power, 1994, India's Electricity Sector-Widening the Scope for Private Participation, New Delhi.

GOI, Office of the Economic Adviser, 1995, Handbook of Industrial Policy and Statistics 1995, New Delhi.

GOI Planning Commission, 1995, Working of State Electricity Boards and Electricity Departments, New Delhi, India.

GOI, 1996, Press Information Bureau.

Green, J., 1994, “Trends and Outlook for Biomass Energy," Energy Engineering. 
Hill, D., 1983, Effect of Scale and Quantity on the Cost and Performance of Energy Technologies: A Literature Review, November.

Hoff, T.E. and C. Herig, "Managing Risk Using Renewable Energy Technologies," forthcoming in The Virtual Utility: Accounting, Technology \& Competitive Aspects of the Emerging Industry, Shimon Awerbuch and Alistair Preston, eds., KLUWER Academic Publishers, Norwell, MA.

Independent Power Quarterly, 1994, 1st Quarter.

International Labor Organization (ILO), 1993 \& 1994, Statistics on Occupational Wages and Hours of Work and on Food Prices.

Ishiguro, M. and T. Akiyama, 1995, Energy Demand in Five Major Asian Developing Countries: Structure and Prospects, World Bank Discussion Paper \#277, World Bank: Washington, DC.

Jones, D.W., A.P. Sanghvi, and E.L. Hillsman, 1988, The Impacts of Inadequate Electricity Supply in Developing Countries, Oak Ridge National Laboratory: TN, August.

Makansi, J., 1994, “Are Fuel Cells Heir Apparent to the Gas Turbine?” Power, June.

Malstrom, E.M., ed., 1981, What Every Engineer Should Know about Manufacturing Cost Estimating, Marcel Dekker, Inc.: New York.

McLanahan J.C., 1994, Cost and Error Characteristics of Three Cost Accounting System Types: Full Cost Accounting, Marginal Costing, and Activity Based Costing, Journal of Cost Analysis, p. 141.

McGraw Hill, 1996, International Private Power Quarterly-Fourth Quarter.

Miller Freeman Publications, 1994, International Pulp \& Paper Directory, Califomia.

Monn, M., 1995, "Project Brings Fuel Cell Closer to Utility Use,” Power, April, pp. 76-79.

National BioEnergy Industries Association (NBIA), 1995, Bagasse-Based Cogeneration in India: A Market Primer for U.S. Companies, Washington, DC.

Nussbaum, D.A., 1994, "Evaluation of an Altemative Estimator of Leaming Curve Lot Midpoints," The Journal of Cost Analysis, Spring, pp. 1-16.

“One Watt at a Time,” 1996, The Economist, September 7, pp.65-66.

Pathak, R.S., "International Trade and Environmental Development: A View from India," Global Legal Studies Journal I.

Ravindranth, N.H., 1993, "Biomass Gasification: Environmentally Sound Technology for Decentralized Power Generation, A Case Study from India." Biomass and Bioenergy, vol. 4, no.1, pp. 49-60.

Rizzie, J.W., F.M. Picker, and W.W. Freve, Jr., 1996, "Startup and Operation of a Biomass-Fueled Combustion Turbine Commercial Demonstration Power Plant," in proceedings from Bioenergy '96-The Seventh National Bioenergy Conference, September 15-20, pp. 393-401.

Salvendy, G., ed., 1982, Handbook of Industrial Engineering, John Wiley \& Sons: New York. 
Samudrala, S., 1995, “Opportunity Emerges,” Independent Energy, vol. 25, no. 1.

Schramm, G., 1993, Rural Electrification in LDCs as a Tool for Economic Development: Fact and Fiction, prepared for OPEC Review, April.

Steiner, H.M., 1989, Basic Engineering Economy, Books Associates: Glen Echo, MD.

Stirling Thermal Motors, 1996, personal communication, October.

Stump, E.J., 1987, "Composite Leaming Curves for Fast Estimating," The Journal of Cost Analysis, vol.5, no.1, Summer, pp. 59-69.

Sunpower Inc., 1996, 2.5 kW Stirling Engine Electric Generator, November.

Swanekamp, R., 1995, “Fuel Cells Inch Towards Mainstream Power Duties,” Power, June, pp.82-92.

Tata Energy Research Institute (TERI), 1996, TERI Energy Data Directory \& Yearbook (TEDDY) 1995/96, New Delhi, India.

Tata Energy Research Institute (TERI), 1991, TERI Energy Data Directory \& Yearbook (TEDDY) 1990/91, New Delhi, India.

Turvey, R. and D. Anderson, 1977, Electricity Economics, Essays and Case Studies, Baltimore, MD: Johns Hopkins University Press.

U.S. Agency for International Development (USAID), 1988, Power Shortages in Developing Countries: Magnitude, Impacts, Solutions, and the Role of the Private Sector, A Report to Congress, March, Washington, DC.

U.S. Department of Agriculture, 1995, Sugar \& Sweetener S\&O, vol. 20, no. 2.

U.S. Department of Energy, 1994, Foreign Markets for Clean Coal Technologies, Report to U.S. Congress, May 2, DOE/FE-0317.

USDOE/EIA, 1994, International Energy Annual.

USDOE/EIA, 1996, International Energy Outlook 1996, DOE/EIA-0484(96), May.

Utility Data Institute (UDI), 1996, International Directory of Electric Utilities, 8th Edition, UDI:

Washington, DC, January.

Vijay, V.K., R. Prasad, J.P. Singh, V.P.S. Sorayan, 1996, “A Case for Biogas Energy Application for Rural Industries in India," in Proceedings from the World Renewable Energy Congress, vol. II, Denver, CO, June 15-21, pp.993-996.

World Bank, 1994, World Development Report 1994: Infrastructure for Development, Oxford University Press: New York.

Ziph, B., Stirling Thermal Motors (STM), 1996, personal communication and literature. 


\section{APPENDIX A}

\section{Assumptions and Calculations of Relevant Plant Costs}




\section{ASSUMPTIONS \& CALCULATIONS}

\section{COST ALLOCATION RATIOS}

\section{Construction Costs Relative to Total Plant Costs}

Source: EPRI, "Technical Assessment of the Indirect-Fired Gas Turbine Power Plant," September 1989

Table 8-3, Scale 9.6 MW - Indirect Fired CT

$\begin{array}{lll}\text { Total Installed Cost } & = & \$ 18,264,000 \\ \text { Construction \& Management } & = & \$ 1,778,953 \\ \text { Labor as \% of TPC } & = & 9.7 \%\end{array}$

Table 8-3, Scale 15.9 MW - Combined Cycle Plant

$\begin{array}{lll}\text { Total Installed Cost } & = & \$ 15,899,000 \\ \text { Construction \& Management } & = & \$ 1,548,629 \\ \text { Labor as \% of TPC } & =9.7 \%\end{array}$

Source: EIA, "Projected Costs of Electricity from Nuclear and Coal Fired Power Plants," August 1982

Table 4, 600 MW Coal Plant, in $\$ 1980$

$\begin{array}{lll}\text { Labor Content } \$ / \mathrm{kW} & = & 11.4 \\ \text { Labor Rate in } \$ 1996 & = & \$ 15.04 / \mathrm{h} \\ \text { CPI 1980/1996 } & = & 60 / 110=.55 \\ \text { Labor Rate in } \$ 1980 & = & \$ 15.04(.55)=\$ 8.20 / \mathrm{h} \\ \text { Labor Content } \$ / \mathrm{kW} & = & (11.4)(8.20)=\$ 94 \\ \text { Total Plant Costs }(\$ / \mathrm{kW}) & = & \$ 975 \\ \text { Labor as \% of TPC } & = & 9.6 \%\end{array}$

Source: EPRI AP 5950, IGCC Capital Cost Estimates

Field Labor

$\begin{array}{llr}\text { Field Labor } & & 75 \mathrm{M} \\ \text { Field Material } & = & 295 \mathrm{M} \\ \text { Sub Labor } & = & 25 \mathrm{M} \\ \text { Sub Materials } & = & 150 \mathrm{M} \\ \text { Indirect and Engineering } & = & 109 \mathrm{M} \\ \text { Total Cost } & = & 654 \mathrm{M} \\ \text { Labor as \% of TPC } & = & 15.2 \%\end{array}$

Source: EPRI AP 5950, PC Plant Capital Cost Estimates

Field Labor

Field Material

Sub Labor

Sub Materials

$\begin{array}{ll}= & 47 \mathrm{M} \\ = & 84 \mathrm{M} \\ = & 60 \mathrm{M} \\ = & 230 \mathrm{M}\end{array}$

$47 \mathrm{M}$

$60 \mathrm{M}$

$230 \mathrm{M}$ 


$\begin{array}{llc}\text { Indirect and Engineering } & = & 80 \mathrm{M} \\ \text { Total Cost } & = & 501 \mathrm{M} \\ \text { Labor as \% of TPC } & = & 21.3 \%\end{array}$

ASSUMPTION - For larger plants (fuel cells, direct-fired combustion turbine, BIGCC) assumed average of above estimates for Construction as Percent of Total Plant Costs or 13\%. Equipment cost assumed to be (1-labor cost\%, 87\%)

ASSUMPTION - For smaller plants (Stirling engines) assumed based on the following:

In conversations with Craig Hansen, Caterpillar representative,with ALBAN, believed that installation (consisting of leveling and pouring of concrete and bolting down equipment) for $15 \mathrm{~kW}$ system ( $\$ 13,000$ delivered), installation may be $\$ 2,000$.

Delivered cost $\quad=\quad \$ 867 / \mathrm{kW}$

Installation $\quad=\quad \$ 133 / \mathrm{kW}$

Total Installed $\quad=\quad \$ 1,000 / \mathrm{kW}$

Installation/TPC $=13.3 \%$

Assumed labor costs represent $60 \%$ of installation costs

Labor as \% of TPC $=(.133)(0.60)=8 \%$

Equip as \% of TPC $=92 \%$ 


\section{CAPITAL COST CALCULATIONS}

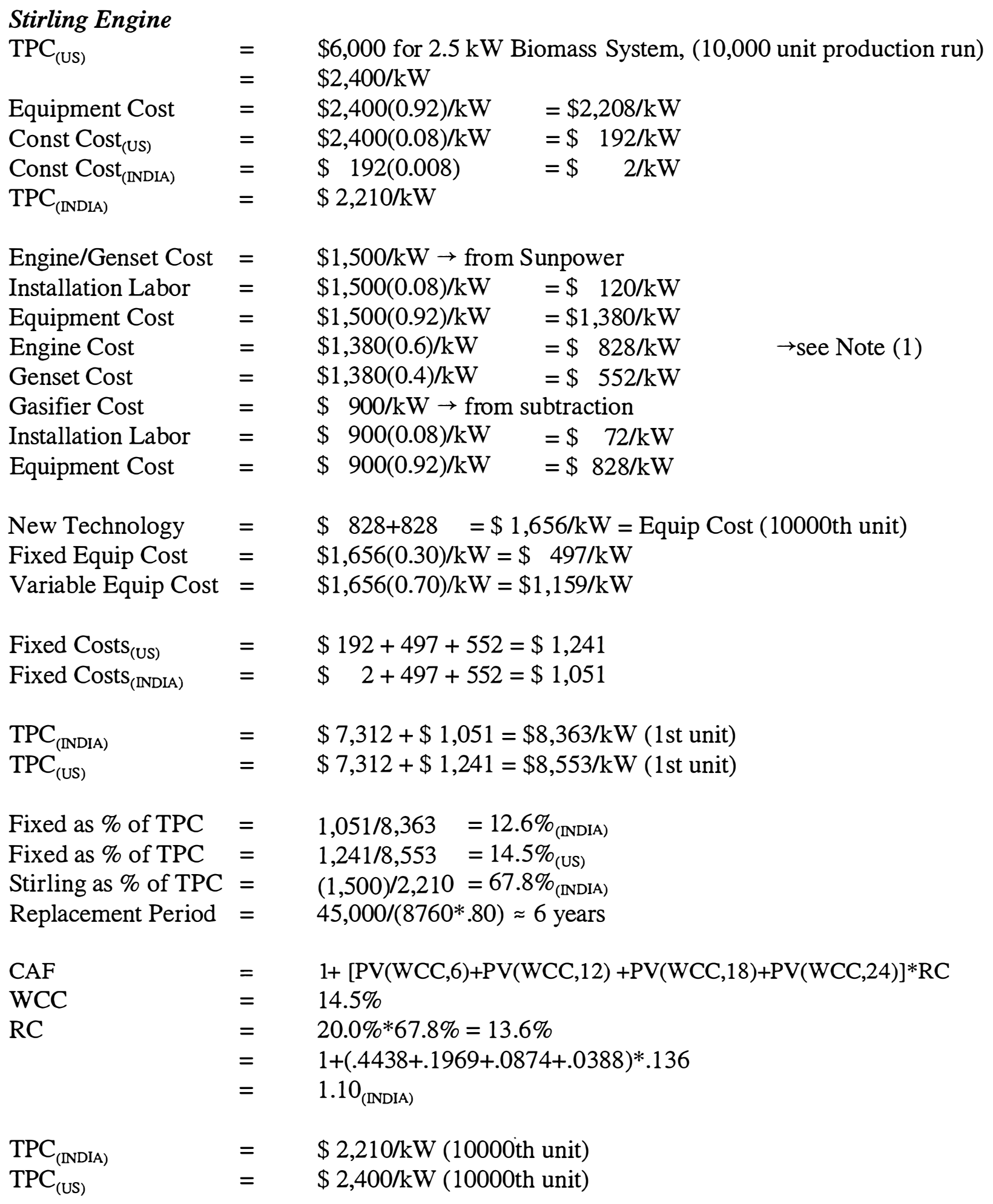

Learning curve applied based on $\mathrm{VC}=\mathrm{KX}^{\mathrm{n}}$, where $\mathrm{n}=-20 \%, \mathrm{VC}=$ Variable Cost, $\mathrm{K}=$ Variable Cost of first unit. TPC $=$ Installation Labor $+\mathrm{VC}+$ Fixed Costs 


\section{Direct-Fired Combustion Turbine}

\begin{tabular}{|c|c|c|c|c|}
\hline $\mathrm{TPC}_{(\mathrm{US})}$ & $\begin{array}{l}= \\
=\end{array}$ & $\begin{array}{l}\$ 7,250,000 \text { for } 5,8 \\
\$ 1,250 / \mathrm{kW}\end{array}$ & $\mathrm{kW} \mathrm{B}$ & mass System, Commercial Demo \\
\hline Equipment Cost & $=$ & $\$ 1,250(0.87) / \mathrm{kW}$ & $=$ & $\$ 1,088 / \mathrm{kW}$ \\
\hline Const Cost & $=$ & $\$ 1,250(0.13) / \mathrm{kW}$ & $=$ & $\$ 162 / \mathrm{kW}$ \\
\hline Const Cost $_{(\text {NDIA })}$ & $=$ & $\$ 165(0.008) / \mathrm{kW}$ & $=$ & $1 / \mathrm{kW}$ \\
\hline $\mathrm{TPC}_{(\mathrm{INDIA})}$ & $=$ & $\$ 1,089 / \mathrm{kW}$ & & \\
\hline Variable Cost & $=$ & $\$ 1,088 / \mathrm{kW}$ & & $\rightarrow$ see Note (3) \\
\hline Fixed Costs(US) & $=$ & $\$ 162 / \mathrm{kW}$ & & \\
\hline Fixed Costs $_{(\mathrm{NDIA})}$ & $=$ & $\$ \quad 1 / \mathrm{kW}$ & & \\
\hline Fixed as $\%$ of TPC & $=$ & $\$ 1 / 1,089$ & $=$ & $0.1 \%_{(\mathrm{INDIA})}$ \\
\hline Fixed as $\%$ of TPC & $=$ & $\$ 162 / 1250$ & $=$ & $13.0 \%_{(\mathrm{US})}$ \\
\hline $\mathrm{TPC}_{(\mathrm{NDIA})}$ & $=$ & $\$ 906 / \mathrm{k}$ & unit) & \\
\hline $\mathrm{TPC}_{(\mathrm{US})}$ & $=$ & $\$ 1,067 / \mathrm{kW}(1000 \mathrm{c}$ & unit) & \\
\hline
\end{tabular}

Learning curve applied based on $\mathrm{VC}=\mathrm{KX}^{\mathrm{n}}$, where $\mathrm{n}=-2 \%, \mathrm{VC}=$ Variable Cost, $\mathrm{K}=$ Variable Cost of first unit. TPC $=$ Installation Labor $+\mathrm{VC}+$ Fixed Costs

\section{Fuel Cells}

Stack Replacement Costs Relative to Initial Turnkey Fuel Cell Plant Costs

Source: ERC, Personal communication, January 1997, and Direct Fuel Cell Power Plants:

Demonstrations and Commercial Units, June, 1995

Estimates Provided in 1990 Dollars

Natural Gas Fueled MCFC Cost Specifications

Turnkey MCFC System Costs

1st Generation

2nd Generation

Stack Replacement Costs*

$\$ 2,250 / \mathrm{kW}$

$\$ 1,500 / \mathrm{kW}$

$\%$ Stack Replace as Total MCFC*

$\$ 300 / \mathrm{kW}$

$\$ 200 / \mathrm{kW}$

$13.3 \%$

$13.3 \%$

* Assumes that ratio of stack replacement costs to initial capital investment is the same for future plants that it is for first generation plants. These cost reductions are estimated to occur through manufacturing economies and not any technological breakthroughs associated with the fuel cells.

1996 Dollars using CPI $=1.18$

Natural Gas Fueled MCFC Cost Specifications

Turnkey MCFC System Costs

1st Generation

$\$ 2,655 / \mathrm{kW}$ 2nd Generation

$\$ 1,770 / \mathrm{kW}$ 
Stack Replacement Costs*

$\%$ Stack Replace as Total MCFC*

Cost Scaling Performed Using

scaler $=0.8$
$\$ 354 / \mathrm{kW}$

$13.3 \%$
$\$ 236 / \mathrm{kW}$

$13.3 \%$

\section{Indirect-Gasification Plant Costs, estimated for 2.40 MW MCFC}

Net Plant Output (MW)

Gasifier Feed Rate (tpd) @ 11\%MCW

Gasification, Gas Clean-up

Gasification Subtotal
$\underline{\mathrm{MCFC}}$

2.40

35

$\$ 2,298,595$

957
Reference

122

1,640

$\$ 49,898,000$

409

* Gasification cost analysis assumes no difference in cost structure for gasification (besides scaling) between first and second generation fuel cell plants. Refer to Capital Cost Assumptions for breakouts of contingencies and other mark-ups applied.

**Although included in the analysis, sample figure does not include contingencies or other mark-ups.

$\mathrm{TPC}_{\text {(US) }}=\$ 8,438,400$ for $2,400 \mathrm{~kW}$ Biomass System, 1 st unit

$=\$ 3,612 / \mathrm{kW}=2,655+957 \rightarrow$ see Explanation for Gasifier cost

Equipment Cost $=\$ 3,612(0.87) / \mathrm{kW}=\$ 3,142 / \mathrm{kW}$

Const Cost $_{(\mathrm{US})} \quad=\$ 3,612(0.13) / \mathrm{kW}=\$ 469 / \mathrm{kW}$

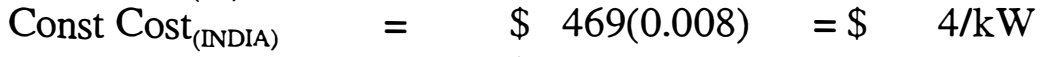

$\mathrm{TPC}_{(\mathrm{INDA})}=\$ 3,146 / \mathrm{kW}$

Fuel Cell Cost $\quad=\quad \$ 2,655 / \mathrm{kW} \quad \rightarrow$ from ERC Estimate

Installation Labor $_{(\mathrm{US})}=\$ 2,655(0.13) / \mathrm{kW}=\$ 345 / \mathrm{kW}$

Installation Labor $_{(\mathbb{N})}=\$ 2,655(0.13)(.008) / \mathrm{kW}=\$ 3 / \mathrm{kW}$

Equipment Cost $=\$ 2,655(0.87) / \mathrm{kW}=\$ 2,310 / \mathrm{kW}$

Fixed Equip Cost $=\$ 2,310(0.30) / \mathrm{kW}=\$ 693 / \mathrm{kW}$

Variable Equip Cost $=\$ 2,310(0.70) / \mathrm{kW}=\$ 1,617 / \mathrm{kW}$

Gasifier Cost $\quad=\quad \$ 957 / \mathrm{kW} \rightarrow$ estimated from BIGCC costs

Installation Labor $=\$ 957(0.13) / \mathrm{kW}=\$ 124 / \mathrm{kW}$

Equipment Cost $=\$ 957(0.87) / \mathrm{kW}=\$ 833 / \mathrm{kW}$

Fixed Equip Cost $=\$ 833(0.30) / \mathrm{kW}=\$ 250 / \mathrm{kW}$

Variable Equip Cost $=\$ 833(0.70) / \mathrm{kW}=\$ 583 / \mathrm{kW}$

Variable Cost $=\$ 1,617+583=\$ 2,200 / \mathrm{kW}$

Fixed Costs $_{\text {(US) }}=\$ 469+693+250=\$ 1,412 / \mathrm{kW}$

Fixed Costs $_{(\mathrm{NDIA})}=\$ 4+693+250=\$ 947 / \mathrm{kW}$ 
Fixed as \% of TPC $=947 / 3,146=30.1 \%_{(\text {INDIA })}$

Fixed as $\%$ of TPC $=1,412 / 3,612=39.1 \%_{(\mathrm{US})}$

MCFC as \% of TPC $=2,313 / 3,146=73.5 \%_{(\text {INIA) }}$

Replacement Period $=40,000 /(8760 * .80) \approx 6$ years

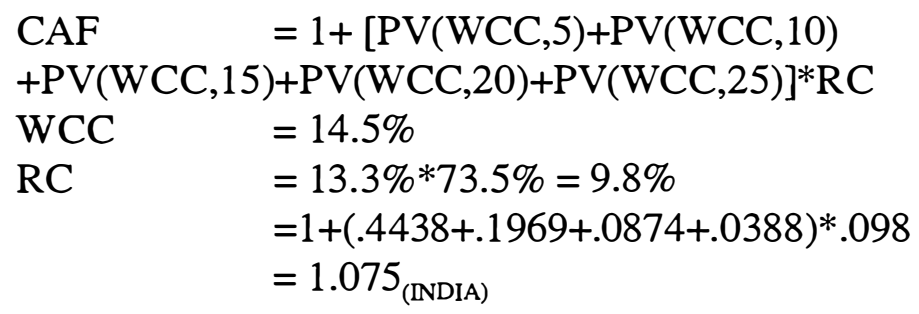

50th U.S. Unit Cost $=1,412+2,200(50)^{-.25}=\$ 2,239$

$\mathrm{X}=25 \%$, based on low end airplane production exponent

$\mathrm{TPC}_{\text {(INDIA) }}=\$ 947+220=\$ 1,167 / \mathrm{kW}(10,000$ th unit $)$

$\mathrm{TPC}_{\text {(US) }}=\$ 1,412+220=\$ 1,632 / \mathrm{kW}(10,000$ th unit $)$

Learning curve applied based on $\mathrm{VC}=\mathrm{KX}^{\mathrm{n}}$, where $\mathrm{n}=-25 \%, \mathrm{VC}=$ Variable Cost, $\mathrm{K}=$ Variable Cost of first unit. TPC $=$ Installation Labor + VC + Fixed Costs

\section{$B I G C C$}

$\mathrm{TPC}_{(\mathrm{US})}$ $=\$ 135,211,000$ for $122,000 \mathrm{~kW}$ Biomass System, 1st unit, 1990 dollars

CPI $=\$ 1,108 / \mathrm{kW}$

$=1.18$

$=\$ 1,307,1996$ dollars

Equipment Cost $\quad=\$ 1,307(0.87) / \mathrm{kW}=\$ 1,137 / \mathrm{kW}$

Const Cost $_{\text {(US) }} \quad=\$ 1,307(0.13) / \mathrm{kW}=\$ 170 / \mathrm{kW}$

Const $\operatorname{Cost}_{\text {(NDIA) }}=\$ 170(0.008) / \mathrm{kW}=\$ \quad 1 / \mathrm{kW}$

$\mathrm{TPC}_{\text {(INDIA) }}$ $=\$ 1,138 / \mathrm{kW}$

GT \& BOP $\quad=\$ 898 / \mathrm{kW} \rightarrow$ from subtraction

Installation Labor $\quad=\$ 898(0.13) / \mathrm{kW}=\$ 117 / \mathrm{kW}$

Equipment Cost $\quad=\$ 898(0.87) / \mathrm{kW}=\$ 781 / \mathrm{kW}$

Fixed Equip Cost $\quad=\$ 781(1.00) / \mathrm{kW} \quad=\$ 781 / \mathrm{kW} \rightarrow$ Note (4)

Variable Equip Cost $=\$ 781(0.00) / \mathrm{kW} \quad=\$ \quad 0 / \mathrm{kW}$

Gasification Plant Costs Estimates Provided in 1990 Dollars for 1640 TPD System

Wood Feed Rate (tpd) @ 50\% MCW

Wood Handling

Wood Drying

Gasifier Feed Rate (tpd) @11\%MCW

Gasification, Gas Clean-up

$$
\begin{array}{lr}
= & 2,915 \\
=\$ & 4,400,000 \\
=\$ & 5,448,000 \\
= & 1,640 \\
= & 20,039,000 \\
= & 29,887,000
\end{array}
$$

Total Gasification Plant 


\begin{tabular}{|c|c|c|}
\hline Engineering, General & Plant, Cont (40\%) & $2,289,894$ \\
\hline Gasification $(\$ / \mathrm{kW})$ & $=\$$ & $346(\$ 1990)$ \\
\hline Gasification $(\$ / \mathrm{kW})$ & $=\$$ & 409 (\$1996) \\
\hline Gasifier/Wood & & \\
\hline Handling Cost & $=\$ 409 / \mathrm{kW}, 1996$ dollar & $\rightarrow$ Note (5) \\
\hline Installation Labor & $=\$ 409(0.13) / \mathrm{kW}=\$ 5$ & $/ \mathrm{kW}$ \\
\hline Equipment Cost & $=\$ 409(0.87) / \mathrm{kW}=\$ 35$ & $/ \mathrm{kW}$ \\
\hline Fixed Equip Cost & $=\$ 356(0.30) / \mathrm{kW}=\$ 10$ & $/ \mathrm{kW}$ \\
\hline Variable Equip Cost & $=\$ 356(0.70) / \mathrm{kW}=\$ 24$ & $/ \mathrm{kW}$ \\
\hline Variable Cost & $=\$ 249$ & \\
\hline Fixed Costs (US) & $=\$ 170+781+107=\$$ & $058 / \mathrm{kW}$ \\
\hline Fixed Costs $_{(\mathrm{INDIA})}$ & $1+781+107=\$$ & $889 / \mathrm{kW}$ \\
\hline Fixed as $\%$ of TPC & $=889 / 1,138=78.2 \%$ & IDIA) \\
\hline Fixed as $\%$ of TPC & $=1,058 / 1,307=80.9 \%$ & \\
\hline $\mathrm{TPC}_{(\mathrm{INDIA})}$ & $=\$ 889+39=\$ 928 /$ & W (10,000th unit) \\
\hline $\mathrm{TPC}_{(\mathrm{US})}$ & $=\$ 1,058+39=\$ 1,097 / 1$ & W (10,000th unit) \\
\hline
\end{tabular}

Learning curve applied based on $\mathrm{VC}=\mathrm{KX}^{\mathrm{n}}$, where $\mathrm{n}=-20 \%, \mathrm{VC}=$ Variable Cost, $\mathrm{K}=$ Variable Cost of first unit. TPC $=$ Installation Labor $+\mathrm{VC}+$ Fixed Costs

\section{O\&M COST ALLOCATIONS}

\section{Efficiency Calculations}

$$
\begin{aligned}
\text { Net Plant Efficiency } & =\frac{3,412 \text { Btu/kWh }}{\text { Net Plant Heat Rate }} \\
\eta_{H H V} & =\frac{\eta_{L H V}}{1.11}
\end{aligned}
$$

Gasification Efficiencies - Fuel Cell, BIGCC system ----> Note (6)

Used $77 \%$ conversion efficiency

\section{Gasification Efficiencies - Stirling system}

Used $80 \%$ per Sunpower

System Efficiencies

\section{Stirling Engines}

Used SunPower net plant efficiency of $20 \%$

Net Plant Efficiency $=20.0 \%$ 
Net Plant Heat Rate $=3412 / .200=17,060 \mathrm{Btu} / \mathrm{kWh}$

\section{Direct-Fired Combustion Turbine}

Used BIOTEN Efficiency

Net Plant Efficiency $=25.2 \%$

Net Plant Heat Rate $=3412 / .252=13,500 \mathrm{Btu} / \mathrm{kWh}$

\section{Fuel Cell}

Heat rate for Natural Gas System $=6,350 \mathrm{Btu} / \mathrm{kWh}(\mathrm{LHV}) \rightarrow$ Fuel Cell Engineering Heat rate for Natural Gas System $=6,350 * 1.11=7,049 \mathrm{Btu} / \mathrm{kWh}(\mathrm{HHV})$

Fuel Cell Only Efficiency (HHV) $\quad=3,412 / 7,049=48.4 \%$

Gasification Efficiency $\quad=77 \%$

Net Plant Efficiency

$=(0.77)(0.484)=37.3 \%$

Net Plant Heat Rate

$=3412 / .373=9,148 \mathrm{Btu} / \mathrm{kWh}$ 


\section{$B I G C C$}

Used “Cost and Performance...", NREL report for efficiency.

Net Plant Efficiency

Net Plant Heat Rate

$$
\begin{aligned}
& =35.4 \% \\
& =3412 / .354=9,638 \mathrm{Btu} / \mathrm{kWh}
\end{aligned}
$$

\section{O\&M Costs}

\section{Relative Labor Cost Adjustment}

Since staffing would vary across different types of plants, developed an average O\&M laborer cost to use in all calculations.

Average O\&M Costs

\begin{tabular}{|l|c|c|}
\hline & US & INDIA \\
\hline Plant Management $(\$ / \mathrm{hr})$ & 39.36 & 0.16 \\
\hline Plant Administration $(\$ / \mathrm{hr})$ & 14.26 & 0.08 \\
\hline Plant O\&M Laborer $(\$ / \mathrm{hr})$ & 21.51 & 0.09 \\
\hline Average Rate $(\$ / \mathrm{hr})$ & $\mathbf{2 5 . 0 4}$ & $\mathbf{0 . 1 1}$ \\
\hline
\end{tabular}

Note that no consideration was given with respect to the number of individuals

in each category. Although this does vary, the impact on the resulting labor ratio is negligible.

O\&M Labor Ratio $=$ India Wage $/$ US Wage $=0.11 / 25.04=.0044$

\section{Stirling Engines}

See write-up in 7.6.1

\section{Direct-Fired Combustion Turbine}

Given O\& $\mathrm{M}_{\text {(USTOTAL) }}=1.40$ cents $/ \mathrm{kWh}$ or $\$ 610,00 \rightarrow$ BIOTEN

Assumed 2 O\&M operators per shift, $8 \mathrm{hr}$ shifts, 3 shifts/day, 52 weeks/yr

Total regular pay O\&M operator hours $=12,480 / \mathrm{yr}$

Assumed 2 weeks vacation, 6 operators $=480$ hours $/ \mathrm{yr}$ overtime

Assumed 1 plant manager per shift, 50 weeks/year $=2080$ hours per year

$$
\begin{aligned}
& \text { Payroll }_{\text {(USLABOR })}=12,480 \text { hours @ 21.51/h }=268,445 \\
& 480 \text { hours @ }(21.51)(1.5) / \mathrm{h}=15,487
\end{aligned}
$$




\begin{tabular}{|c|c|c|}
\hline 2,080hours@ & $39.36 / \mathrm{h}$ & $\begin{array}{l}=81,8 \\
=365,8\end{array}$ \\
\hline \multicolumn{2}{|c|}{ Ratio of Labor to Total O\&M $=365,801 / 610,000$} & $=60 \%$ \\
\hline \multicolumn{2}{|l|}{ Ratio of Non-Labor to Total O\&M } & $=40 \%$ \\
\hline $\begin{array}{l}\text { O\& } M_{(\text {USLABOR })}=(0.60)(14.0) \\
\text { O\& } M_{(\text {INDIALABOR })}=(8.4)(0.0044)\end{array}$ & \multicolumn{2}{|c|}{$\begin{array}{l}=8.4 \mathrm{mils} / \mathrm{kWh} \\
=0.0 \mathrm{mills} / \mathrm{kWh}\end{array}$} \\
\hline $\begin{array}{l}\text { O\& } \mathrm{M}_{\text {(MATERIALS })}=14.0-8.4 \\
\text { O\&M } \\
\text { (TOTALINDIA })\end{array}$ & \multicolumn{2}{|c|}{$\begin{array}{l}=5.6 \mathrm{mils} / \mathrm{kWh} \\
=5.6 \mathrm{mils} / \mathrm{kWh}\end{array}$} \\
\hline
\end{tabular}

\section{Fuel Cell}

For Fuel Cell part of plant, Assumed one operator per shift

Regular time $=52$ weeks, 3 shifts, $8 \mathrm{hrs} /$ day $=6,240 \mathrm{~h} / \mathrm{yr}$

Over time $\quad=2$ weeks, 3 shifts, $8 \mathrm{hrs} /$ day $=240 \mathrm{~h} / \mathrm{yr}$

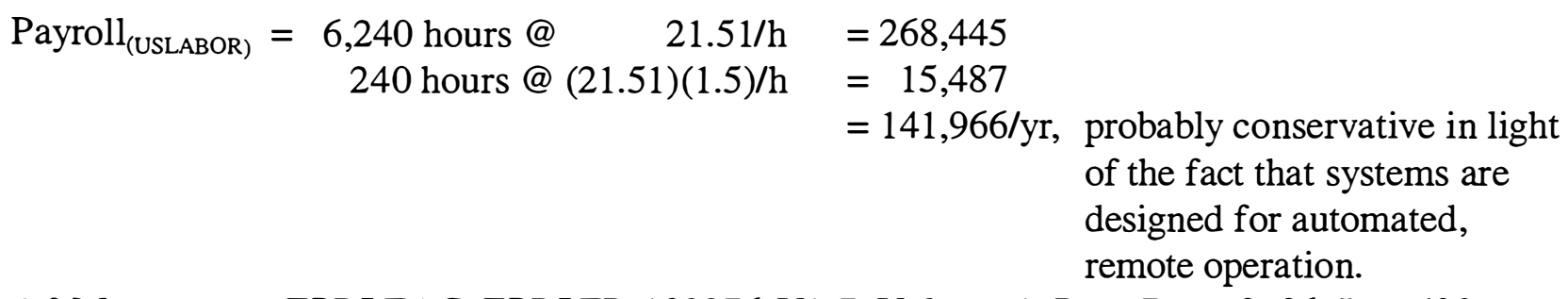

O\&M$M_{\text {(MATERIALS) }}$ EPRI TAG, EPRI TR-102276-V1r7, Volume 1: Rev. 7, pp. 8-86, June ‘93 Variable \& Consumable Operating Expenses $=0.4 \mathrm{mils} / \mathrm{kWh}$

For Gasifier, assumed $1 \mathrm{man} / \mathrm{shift}, 3$ shifts/day, for fuel handling and operation. See above

Payroll $_{(\text {USLABOR })}=\$ 141,966$

O\& $\mathrm{M}_{\text {(MATERIALS) }}$, assumed $5 \%$ of capital cost, $\rightarrow$ Note (7)

$(0.05) * 957 / \mathrm{kW} * 2,400 \mathrm{~kW}=\$ 114,840 / \mathrm{yr}$

Assuming Net Generation of 2.40 MWs @ 80\% CF, Total Generation=16,819,200 kWh

Total Plant

\begin{tabular}{|c|c|}
\hline $\begin{array}{l}\text { O\&M } \\
\text { O\&USLABOR) } \\
\text { OMATERIALS) }\end{array}$ & $\begin{array}{l}=\$ \\
=\$ .0004(19,622,400)+\$ 114,840=\$ 122,689\end{array}$ \\
\hline $\begin{array}{l}\text { O\&M } \\
\text { O\&SLABOR) } \\
\text { O\&M } \\
\text { OMATERIALS) } \\
\text { \& } \mathbf{M}_{\text {(USTOTAL) }}\end{array}$ & $\begin{array}{l}=16.8 \mathrm{mils} / \mathrm{kWh} \\
=7.3 \mathrm{mils} / \mathrm{kWh} \\
=24.1 \mathrm{mils} / \mathrm{kWh}\end{array}$ \\
\hline
\end{tabular}




$$
\begin{array}{lll}
\text { O\&M } & =(16.8)(0.0044) & =0.1 \mathrm{mils} / \mathrm{kWh} \\
\text { O\&DIALABOR }) & =0.1+7.3 & =7.4 \mathrm{mils} / \mathrm{kWh}
\end{array}
$$

\section{BIGCC}

Used "Cost and Performance...", NREL report for costs

Water + Other $(\$ \mathrm{~K}) \quad 625$

Ash (\$K) 822

Operating Labor $(\$ \mathrm{~K}) \quad 2,139$

Supervision \& Clerical (\$K) 1,243

Maintenance $(\$ K) \quad 5,013$

Total (\$K) 9,842

O\&M $\mathrm{M}_{\text {(USLABOR) }}=2,139+1,243=3,382$

Labor as Ratio to total $\quad=3,382 / 9,842=34 \%$

Materials as Ratio to total $=66 \%$

USED ------> 40\% labor, 60\% materials

\begin{tabular}{|c|c|c|}
\hline O\& $\mathbf{M}_{\text {(USTOTAL) }}$ & $=9,842,000 / 854,976,000$ & $=11.5 \mathrm{mils} / \mathrm{kWh}$ \\
\hline O\&M $M_{(U S L A B O R)}$ & $=11.51(0.40)$ & $=4.6 \mathrm{mils} / \mathrm{kWh}$ \\
\hline O\& $\mathbf{M}_{\text {(MATERIALS) }}$ & $=4.6 \mathrm{mils} / \mathrm{kWh}$ & $=6.9 \mathrm{mils} / \mathrm{kWh}$ \\
\hline $\mathrm{O} \& \mathrm{M}_{\text {(INDIALABOR) }}$ & $=(4.6)(0.0044)$ & $=0.0 \mathrm{mils} / \mathrm{kWh}$ \\
\hline O\&M $M_{\text {(INDIATOTAL) }}$ & $=0.0+6.9$ & $=6.9 \mathrm{mils} / \mathrm{kWh}$ \\
\hline
\end{tabular}

Total Generation @ 80\% CF $=(8,760) *(0.80) *(122,000)=854,976,000$

Fuel Costs

Fuel Consumption Cost $=\frac{\text { Btus }}{k W h} * \frac{1 \text { MMBtu }}{1,000,000 B t u s} * \frac{\text { Fuel } \$}{M M B t u} * \frac{100 \text { cents }}{\$}$

\section{Stirling Engine}

Net Plant Heat Rate (Btus/kWh) $\quad=17,060 \mathrm{Btu} / \mathrm{kWh}$

High Fuel Cost ( $\$ / \mathrm{MMBtu}) \quad=\$ 1.25$

Low Fuel Cost (\$/MMBtu) $\quad=\$ 0.54$

Fuel Cost (High) $_{(\text {in }}$

Fuel Cost (Low) $_{\text {Low }}$

$=2.13$ cents $/ \mathrm{kWh}$

$=0.92$ cents $/ \mathrm{kWh}$

\section{Direct-Fired Combustion Turbine}

Net Plant Heat Rate (Btus/kWh) $\quad=13,500 \mathrm{Btu} / \mathrm{kWh}$

High Fuel Cost $(\$ / M M B t u) \quad=\$ 1.25$ 
Low Fuel Cost (\$/MMBtu)

Fuel Cost (High) $_{(10)}$

Fuel Cost (Low) $_{\text {ow }}$
$=\$ 0.54$

$=1.69$ cents $/ \mathrm{kWh}$

$=0.73$ cents $/ \mathrm{kWh}$

\section{Fuel Cell}

\begin{tabular}{|c|c|}
\hline Net Plant Heat Rate (Btus/kWh) & $=9,148 \mathrm{Btu} / \mathrm{kWh}$ \\
\hline High Fuel Cost (\$/MMBtu) & $=\$ 1.25$ \\
\hline Low Fuel Cost (\$/MMBtu) & $=\$ 0.54$ \\
\hline Fuel Cost ${ }_{(\mathrm{High})}$ & $=1.14$ cents $/ \mathrm{kWh}$ \\
\hline Fuel Cost (Low) & $=0.49$ cents $/ \mathrm{kWh}$ \\
\hline
\end{tabular}

\section{BIGCC}

Net Plant Heat Rate (Btus/kWh)

$=9,638 \mathrm{Btu} / \mathrm{kWh}$

High Fuel Cost (\$/MMBtu)

$=\$ 1.25$

Low Fuel Cost (\$/MMBtu)

$=\$ 0.54$

Fuel Cost $_{(\text {High) }}$

Fuel Cost (Low $)$

$$
=1.20 \text { cents } / \mathrm{kWh}
$$

$=0.52$ cents $/ \mathrm{kWh}$ 


\section{COAL PLANT ASSUMPTIONS}

\section{PLANT CAPITAL COSTS}

Based on EPRITAG

$\mathrm{TPC}=\$ 1,607 / \mathrm{kW}$ for one $300 \mathrm{MW}$ unit

Assuming moderate scale effect of 0.97 as cited in text

$$
\text { Cost }=\frac{1,607 * 300,000\left(\frac{1,200 M W}{300 M W}\right)^{0.97}}{1,200,000} \quad \text { Cost }=\$ 1,479 / \mathrm{kW}
$$

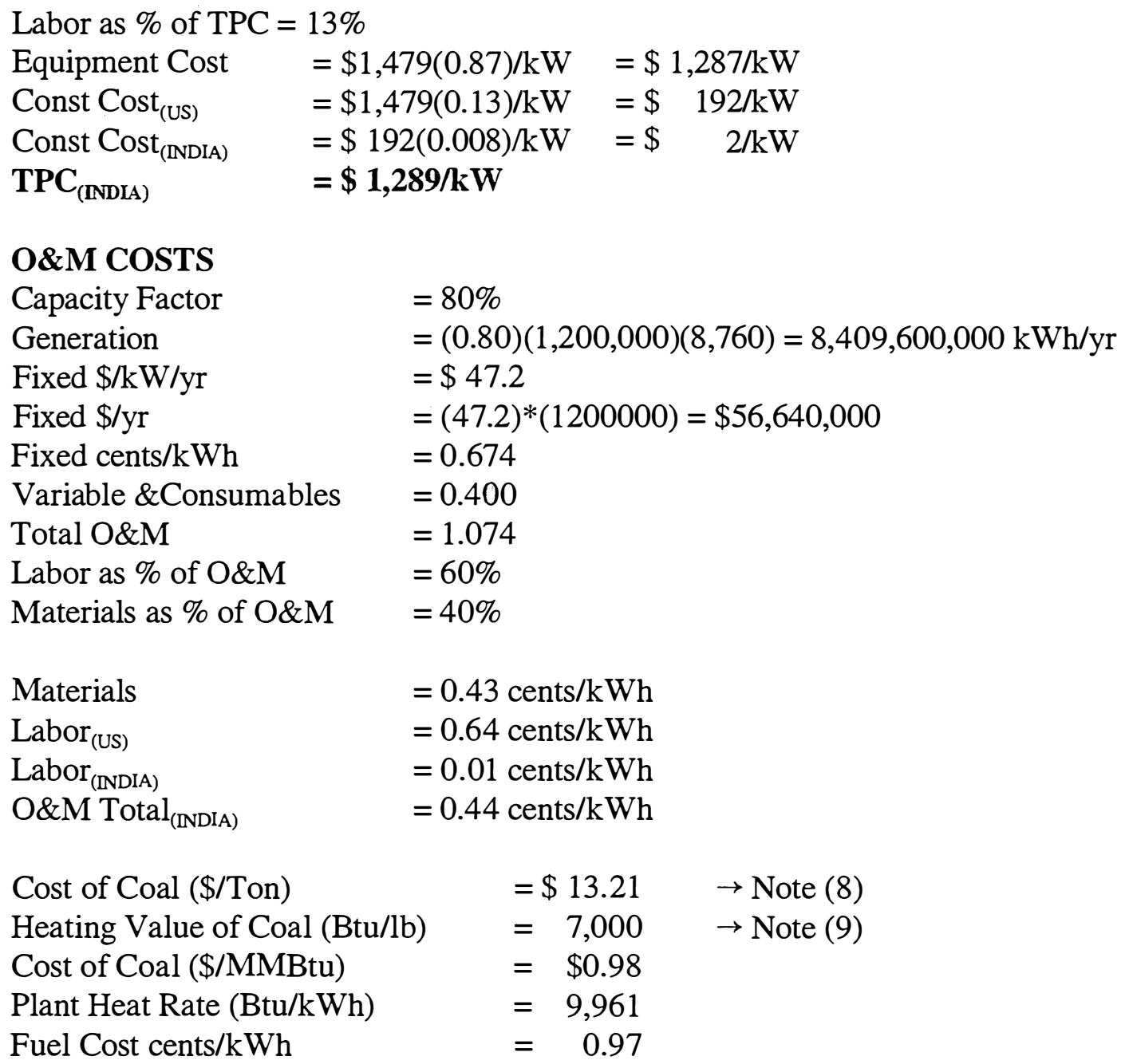


NOTES

1) Based on cost estimates of diesel motor cost as percentage of entire genset cost for China Diesel Inc. $8 \mathrm{~kW}$ system

2) Estimated first unit cost of gasifier and Stirling engine based on assumption of 10000th unit.

3) Assumes that equipment sizing will be optimized in future plants

4) Assumed no learning on this equipment

5) Estimated from "Cost and Performance Analysis of Biomass Based Integrated Gasification Combined Cycle Power Systems"

6) Estimated from "Cost and Performance Analysis of Biomass Based Integrated Gasification Combined Cycle Power Systems" Assumes BCL indirect gasifier will be used.

7) Paisley, Ferris, "Development and Commercialization of a Biomass Gasification/Power Generation System", Second Biomass Conference of the Americas, 1995, p. 559

8) Based on country averages

9) Assumed average based on range of 6000 - $8000 \mathrm{Btu} / \mathrm{lb}, \mathrm{DOE}$,'Foreign Markets for US Clean Coal Technologies," May 1994 


\section{APPENDIX B}

Cost of Electricity Sensitivities 


\section{Stirling Engine Projections \\ Production Progress and Scale Based Cost Reductions HIGH MARKET POTENTIAL SCENARIO}

Teaming Cunve Equation. $Y=K X \wedge n$

$\mathrm{K}=$ Assembly time 1st unit

$X=$ Cuml no. of units produced

$n=-\%$ cost reduction per production doubling

Production Parameters

Initial assembly time constant for 1 st unit (K)

Percent decrease for doubling in cuml production

Variable Cost as \% of Total Manufacturing Cost

100

$-20 \%$

$87.4 \%$

Initial Cost/Size Parameters

Scafing Data Point (Plant Size, kW)

Scaling Data Point (First Unit Cost)

Refurbishment Adjustment Factor

Scaling Exponent

Plant Capacity Factor

\begin{tabular}{lrrr} 
& $\begin{array}{c}\text { Plant } \\
\text { Size (kW) }\end{array}$ & $\begin{array}{c}\text { First Unit } \\
\text { Cost }(\$ / \mathrm{kW})\end{array}$ & $\begin{array}{c}\text { kWh per } \\
\text { Year }\end{array}$ \\
\cline { 2 - 4 } \multicolumn{1}{c}{ Scale 1 } & 2.5 & $\$ 8,740$ & 18,834 \\
Scale 2 & 10.0 & $\$ 8,740$ & 75,336 \\
& 25.0 & $\$ 8,740$ & 188,340 \\
Scale 3 & & & \\
Q\&MCosts (cents/kWhr) & & High & Low \\
O\&M w/o Fuel Cost & & 0.710 & 0.710 \\
Fuel Costs & 2.130 & 0.920 \\
Transmission Costs & & 2.000 & 0.000 \\
Total O\&M Costs & & 2.840 & 1.630
\end{tabular}

Carrving Charge Input Summary

Debt Interest Rate $\quad 12.00 \%$

Debt Fraction $\quad 75.00 \%$

Equity Cost $\quad 22.00 \%$

Equity Fraction $25.00 \%$

Construction Escalation Rate $\quad 4.50 \%$

Construction Time $\quad 0.5$

Book Life

Depreciation Life

Additional Capital Charges

Property Tax \& Insurance $\quad 2.00 \%$

Tax Rate

$40.00 \%$

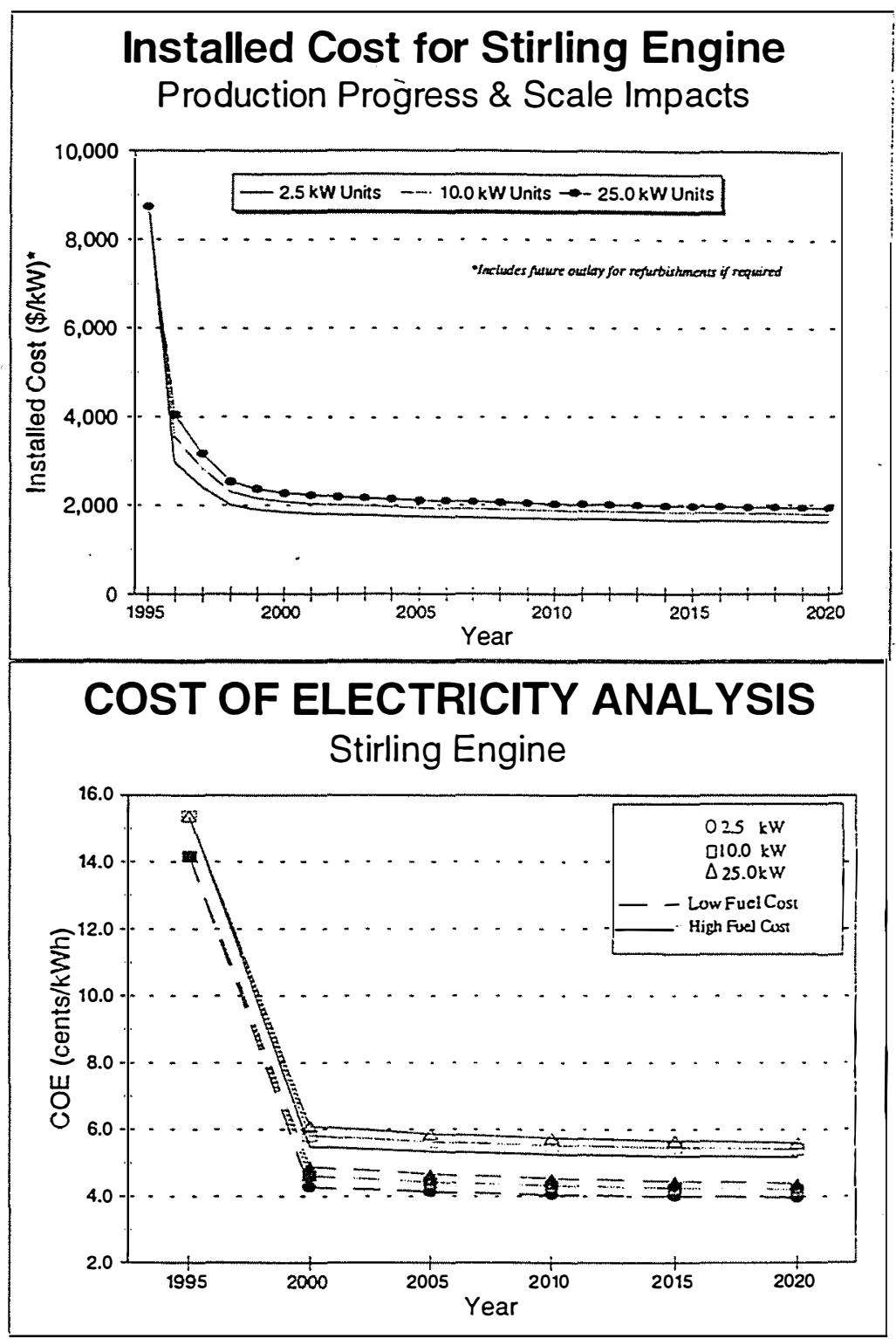

\begin{tabular}{|c|c|c|c|c|c|c|c|c|c|}
\hline \multirow[b]{2}{*}{ Year } & \multicolumn{9}{|c|}{ DATA SUMMARY TABLE } \\
\hline & $\begin{array}{l}\text { Units Year.. } \\
\text { Produced }\end{array}$ & $\begin{array}{c}\text { Cuml } \\
\text { Production }\end{array}$ & $\begin{array}{c}\text { Scale } 1 \\
\text { Installed } \\
\text { Cost }(\$ / k W)\end{array}$ & $\begin{array}{l}\text { Units/Year } \\
\text { Produced }\end{array}$ & $\begin{array}{c}\text { Cuml } \\
\text { Production }\end{array}$ & $\begin{array}{c}\text { Scale 2 } \\
\text { Installed } \\
\text { Cost }(\$ / k W)\end{array}$ & $\begin{array}{l}\text { Units/Year } \\
\text { Produced }\end{array}$ & $\begin{array}{c}\text { Cuml } \\
\text { Production }\end{array}$ & $\begin{array}{c}\text { Scale } 3 \\
\text { Installed } \\
\text { Cost (\$fkW) }\end{array}$ \\
\hline 1995 & 0 & 0 & $\$ 8,740$ & 0 & 0 & $\$ 8,740$ & 0 & 0 & $\$ 8,740$ \\
\hline 2000 & 36,973 & 117.935 & $\$ 1.840$ & 9,243 & 29,484 & $\$ 2,076$ & 3,697 & 11,793 & $\$ 2,272$ \\
\hline 2005 & 25,433 & 245,099 & $\$ 1,740$ & 6,358 & 61,275 & $\$ 1,944$ & 2,543 & 24.510 & $\$ 2,113$ \\
\hline 2010 & 27,092 & 380,558 & $\$ 1,686$ & 6.773 & 95,140 & $\$ 1,873$ & 2,709 & 38,056 & $\$ 2,028$ \\
\hline 2015 & 28,946 & 525,289 & $\$ 1,649$ & 7.237 & 131,322 & $\$ 1,825$ & 2,895 & 52,529 & $\$ 1,970$ \\
\hline 2020 & 30,003 & 675.307 & $\$ 1.622$ & 7.501 & 168.827 & $\$ 1.789$ & 3.000 & 67.531 & $\$ 1.927$ \\
\hline
\end{tabular}

\begin{tabular}{|c|c|c|c|c|c|c|c|c|c|}
\hline \multirow[b]{3}{*}{ Year } & \multirow{3}{*}{$\begin{array}{c}\text { Scale 1 } \\
\text { Carrying } \\
\text { Chrg }(\$ / k W)\end{array}$} & \multirow{3}{*}{$\begin{array}{c}\text { Scale 2 } \\
\text { Carrying } \\
\text { Chrg (\$/kW. }\end{array}$} & \multirow{3}{*}{$\begin{array}{c}\text { Scale } 3 \\
\text { Carrying } \\
\text { Chrg }(\$ / k W)\end{array}$} & \multicolumn{6}{|c|}{ Cost of Electricity Results (cents/kWh) } \\
\hline & & & & \multicolumn{2}{|c|}{ Scale 1} & \multicolumn{2}{|c|}{ Seale 2} & \multicolumn{2}{|c|}{ Seale 3} \\
\hline & & & & $\begin{array}{c}\text { High } \\
\text { Fuel Cost }\end{array}$ & $\begin{array}{l}\text { Low } \\
\text { Fuel Cost }\end{array}$ & $\begin{array}{c}\text { High } \\
\text { Fuel Cost }\end{array}$ & $\begin{array}{c}\text { Low } \\
\text { Fuel Cost }\end{array}$ & $\begin{array}{c}\text { High } \\
\text { Fuel Cost }\end{array}$ & $\begin{array}{l}\text { Low } \\
\text { Fuel Cost }\end{array}$ \\
\hline 1995 & $\$ 944$ & $\$ 944$ & $\$ 944$ & 15.37 & 14.16 & 15.37 & 14.16 & 15.37 & 14.16 \\
\hline 2000 & $\$ 199$ & $\$ 224$ & $\$ 245$ & 5.48 & 4.27 & 5.82 & 4.61 & 6.10 & 4.89 \\
\hline 2005 & $\$ 188$ & $\$ 210$ & $\$ 228$ & 5.33 & 4.12 & 5.63 & 4.42 & 5.87 & 4.66 \\
\hline 2010 & $\$ 182$ & $\$ 202$ & $\$ 219$ & 5.26 & 4.05 & 5.53 & 4.32 & 5.75 & 4.54 \\
\hline 2015 & $\$ 178$ & $\$ 197$ & $\$ 213$ & 5.21 & 4.00 & 5.46 & 4.25 & 5.66 & 4.45 \\
\hline 2020 & $\$ 175$ & $\$ 193$ & $\$ 208$ & 5.17 & 3.96 & 5.41 & 4.20 & 5.60 & 4.39 \\
\hline
\end{tabular}




\section{Stirling Engine Projections \\ Production Progress and Scale Based Cost Reductions \\ LOW MARKET POTENTIAL SCENARIO}

Leaming Cunve Equation. $Y=K X \wedge n$

$\mathrm{K}=$ Assembly time 1st unit

$\mathrm{X}=$ Cuml no. of units produced

$n=-\%$ cost reduction per production doubling .

Production Parameters

initial assembly time constant for 1st unit (K)

Percent decrease for doubling in cuml production

Variable Cost as \% of Total Manufacturing Cost

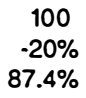

InitialCost / Size Parameters

Scaling Data Point (Plant Size, kW)

Scaling Data Point (First Unit Cost)

Refurbishment Adjustment Factor

Scaling Exponent

Plant Capacity Factor

\begin{tabular}{lrrr} 
& $\begin{array}{c}\text { Plant } \\
\text { Size (kW) }\end{array}$ & $\begin{array}{c}\text { First Unit } \\
\text { Cost }(\$ / k W)\end{array}$ & \multicolumn{1}{c}{$\begin{array}{c}\text { kWh per } \\
\text { Year }\end{array}$} \\
\cline { 2 - 4 } Scale 1 & 2.5 & $\$ 9,200$ & 18,834 \\
Scale 2 & 10.0 & $\$ 9,200$ & 75,336 \\
Scale 3 & 25.0 & $\$ 9,200$ & 188,340 \\
& & & \\
Ssts (cents/kWhr) & & Hiah & Low \\
o Fuel Cost & & 0.710 & 0.710 \\
sts & & 2.130 & 0.920 \\
ission Costs & & 0.000 & 0.000 \\
\&M Costs & & 2.840 & 1.630
\end{tabular}

Camving Charge input Summanx

Debt interest Rate

Debt Fraction

Equity Cost

Equity Fraction

Construction Escalation Rate

Construction Time

Book Life

Depreciation Life

Additional Capital Charges

Property Tax \& Insurance

Tax Rate

$12.00 \%$

$75.00 \%$

$22.00 \%$

$25.00 \%$

$4.50 \%$

0.5
30

1
0

$2.00 \%$

$40.00 \%$

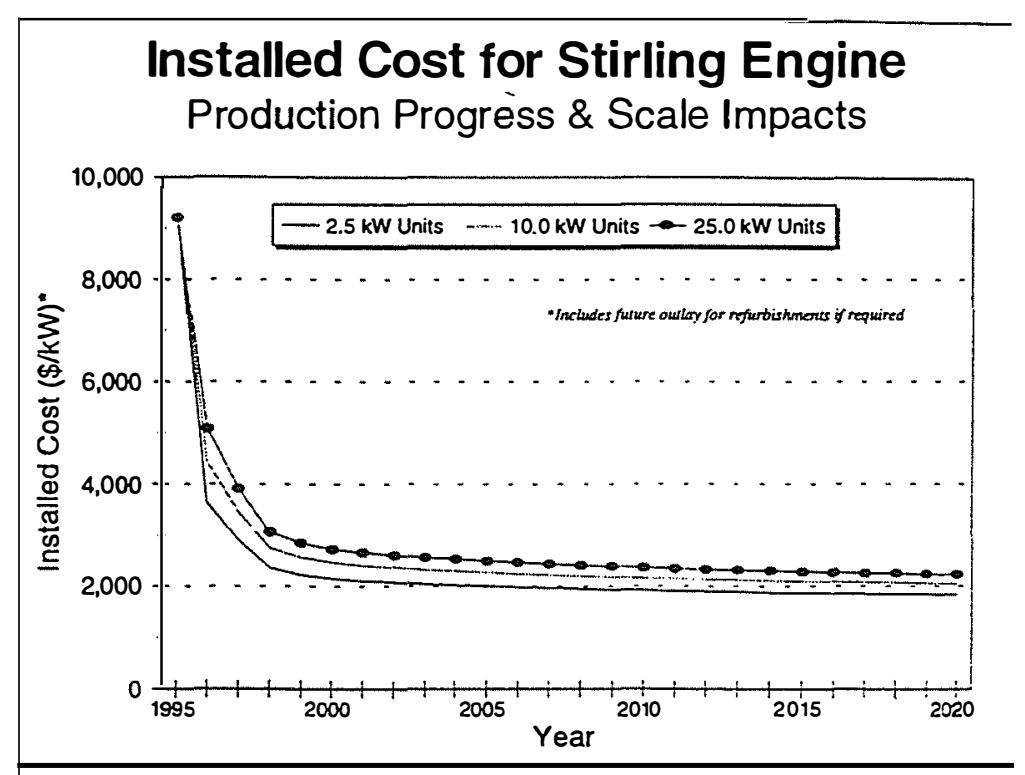

COST OF ELECTRICITY ANALYSIS Stirling Engine

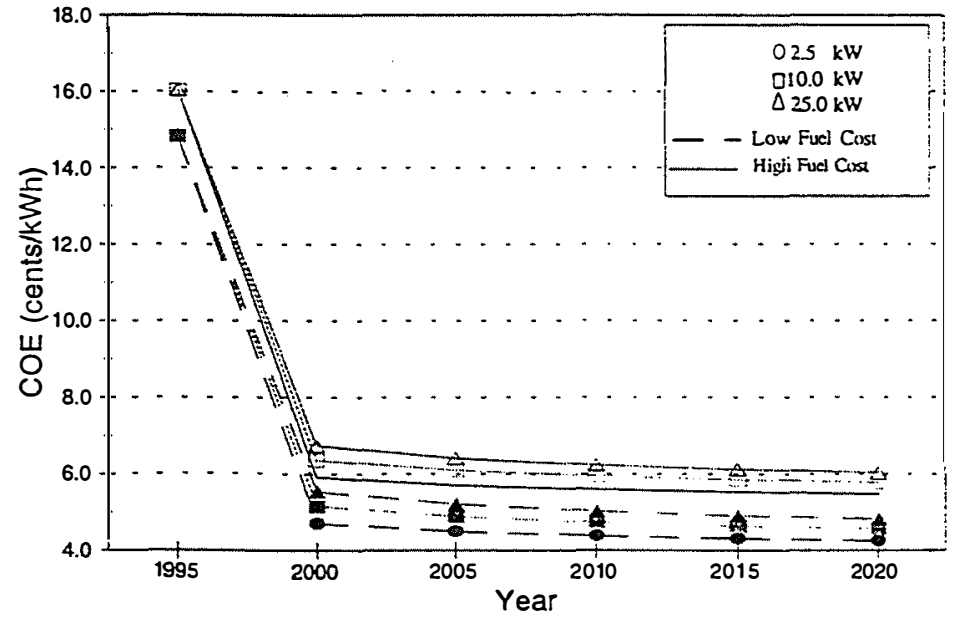

\begin{tabular}{|c|c|c|c|c|c|c|c|c|c|}
\hline \multirow[b]{2}{*}{ Year } & \multicolumn{9}{|c|}{ DATA SUMMARY TABLE } \\
\hline & $\begin{array}{l}\text { Units/year- } \\
\text { Produced }\end{array}$ & $\begin{array}{l}\text { Cuml } \\
\text { Production }\end{array}$ & $\begin{array}{c}\text { Scale 1 } \\
\text { Installed } \\
\text { Cost (\$/kW) }\end{array}$ & $\begin{array}{l}\text { Units/Year } \\
\text { Produced }\end{array}$ & $\begin{array}{c}\text { Cuml } \\
\text { Production }\end{array}$ & $\begin{array}{c}\text { Scale } 2 \\
\text { Installed } \\
\text { Cost (\$/kW) }\end{array}$ & $\begin{array}{l}\text { Unitsqear } \\
\text { Produced }\end{array}$ & $\begin{array}{c}\text { Cuml } \\
\text { Production }\end{array}$ & $\begin{array}{c}\text { Scale } 3 \\
\text { Installed } \\
\text { Cost }(\$ / k W)\end{array}$ \\
\hline 1995 & 0 & 0 & $\$ 9,200$ & 0 & 0 & $\$ 9,200$ & 0 & 0 & $\$ 9,200$ \\
\hline 2000 & 11,405 & 36,380 & $\$ 2,143$ & 2,851 & 9,095 & $\$ 2,458$ & 1,141 & 3,638 & $\$ 2.719$ \\
\hline 2005 & 8,697 & 79,866 & $\$ 2,000$ & 2,174 & 19,966 & $\$ 2,269$ & 870 & 7,987 & $\$ 2.492$ \\
\hline 2010 & 10,346 & 131,594 & $\$ 1,920$ & 2,586 & 32,899 & $\$ 2,163$ & 1,035 & 13,159 & $\$ 2.365$ \\
\hline 2015 & 10,687 & 185,027 & $\$ 1.870$ & 2,672 & 46,257 & $\$ 2,097$ & 1,069 & 18,503 & $\$ 2.286$ \\
\hline 2020 & 11,824 & 244.145 & $\$ 1.832$ & 2.956 & 61.036 & $\$ 2.047$ & 1.182 & 24.415 & $\$ 2.225$ \\
\hline
\end{tabular}

\begin{tabular}{|c|c|c|c|c|c|c|c|c|c|}
\hline \multirow[b]{3}{*}{ Year } & \multirow{3}{*}{$\begin{array}{c}\text { Scale 1 } \\
\text { Carrying } \\
\text { Chrg (s.kW) }\end{array}$} & \multirow{3}{*}{$\begin{array}{c}\text { Scale 2 } \\
\text { Carrying } \\
\text { Chrq }(\$ / \mathrm{kW})\end{array}$} & \multirow{3}{*}{$\begin{array}{c}\text { Scale } 3 \\
\text { Carrying } \\
\text { Chrg }(\$ / k W)\end{array}$} & \multicolumn{6}{|c|}{ Cost of Electricity Results (cents/kWh) } \\
\hline & & & & \multicolumn{2}{|c|}{ Scale 1} & \multicolumn{2}{|c|}{ Scale 2} & \multicolumn{2}{|c|}{ Seale 3} \\
\hline & & & & $\begin{array}{l}\text { High } \\
\text { Fuel Cost }\end{array}$ & $\begin{array}{l}\text { Low } \\
\text { Fuel Cost }\end{array}$ & $\begin{array}{c}\text { High } \\
\text { Fuel Cost }\end{array}$ & $\begin{array}{l}\text { Low } \\
\text { Fuel Cost }\end{array}$ & $\begin{array}{l}\text { High } \\
\text { Fuel Cost }\end{array}$ & $\begin{array}{l}\text { Low } \\
\text { Fuel Cost }\end{array}$ \\
\hline 1995 & $\$ 994$ & $\$ 994$ & $\$ 994$ & 16.03 & 14.82 & 16.03 & 14.82 & 16.03 & 14.82 \\
\hline 2000 & $\$ 232$ & $\$ 266$ & $\$ 294$ & 5.91 & 4.70 & 6.36 & 5.15 & 6.74 & 5.53 \\
\hline 2005 & $\$ 216$ & $\$ 245$ & $\$ 269$ & 5.71 & 4.50 & 6.09 & 4.88 & 6.41 & 5.20 \\
\hline 2010 & $\$ 207$ & $\$ 234$ & $\$ 256$ & 5.59 & 4.38 & 5.94 & 4.73 & 6.23 & 5.02 \\
\hline 2015 & $\$ 202$ & $\$ 227$ & $\$ 247$ & 5.52 & 4.31 & 5.85 & 4.64 & 6.12 & 4.91 \\
\hline 2020 & $\$ 198$ & $\$ 221$ & $\$ 240$ & 5.47 & 4.26 & 5.77 & 4.56 & 6.03 & 4.82 \\
\hline
\end{tabular}




\section{Direct-Fired Combustion Turbine Projections}

\section{Production Progress and Scale Based Cost Reductions HIGH MARKET POTENTIAL SCENARIO}

Leäming Curve Equation. $Y=K X \wedge n$

$\mathrm{K}=$ Assembly time 1st unit

$X=$ Cuml no. of units produced

$n=-\%$ cost reduction per production doubling

Preduction Parameters

Initial assembly time constant for 1 st unit $(K)$

Percent decrease for doubling in cuml production

Variable Cost as \% of Total Manufacturing Cost

Initial cost / Size Parameters

Scaling Data Point (Plant Size, kW)

Scaling Data Point (First Unit Cost)

Refurbishment Adjustment Factor

Scaling Exponent

Plant Capacity Factor

\begin{tabular}{lrrr} 
& $\begin{array}{c}\text { Plant } \\
\text { Size }(k W)\end{array}$ & $\begin{array}{c}\text { First Unit } \\
\text { Cost }(\mathbf{S} / \mathbf{k W})\end{array}$ & \multicolumn{1}{c}{$\begin{array}{c}\text { kWh per } \\
\text { Year }\end{array}$} \\
\cline { 2 - 4 } Scale 1 & $5,800.0$ & $\$ 1,188$ & $40,646,400$ \\
Scale 2 & $10,000.0$ & $\$ 1,106$ & $70,080,000$ \\
Scale 3 & $20,000.0$ & $\$ 1,011$ & $140,160,000$
\end{tabular}

O\&M Cests (cents/kWhr)

O\&M w/o Fuel Cost

Fuel Costs

Transmission Costs

Total O\&M Costs

\begin{tabular}{|c|c|}
\hline High & Low \\
\hline 0.563 & 0.563 \\
\hline 1.690 & 0.730 \\
\hline 0.000 & 2.000 \\
\hline 2.253 & 1.293 \\
\hline
\end{tabular}

Carrying Charge input Summary

Debt Fraction

Equity Cost

Equity Fraction

Construction Escalation Rate

Construction Time

Book Life

Depreciation Life

Additional Capital Charges

Property Tax \& Insurance

TaxRate
$12.00 \%$

$75.00 \%$

$22.00 \%$

$25.00 \%$

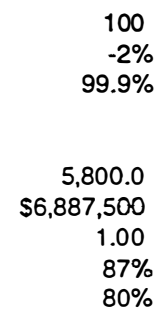

$-2 \%$

$99.9 \%$

00

$80 \%$

$4.50 \%$
0.5

30

0

$2.00 \%$

$40.00 \%$

\section{Installed Cost for Direct-Fired CT}

Production Progress \& Scale Impacts

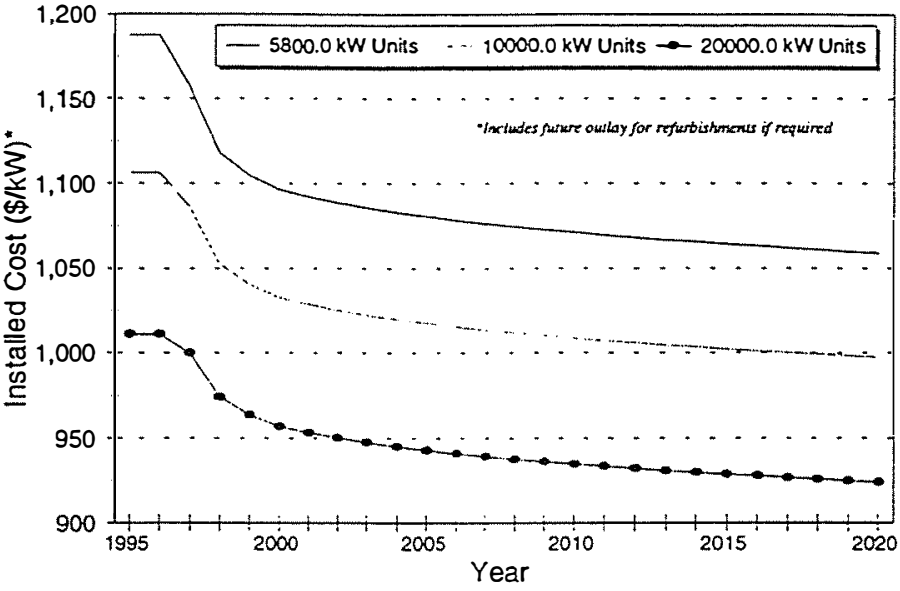

COST OF ELECTRICITY ANALYSIS

Direct-Fired CT

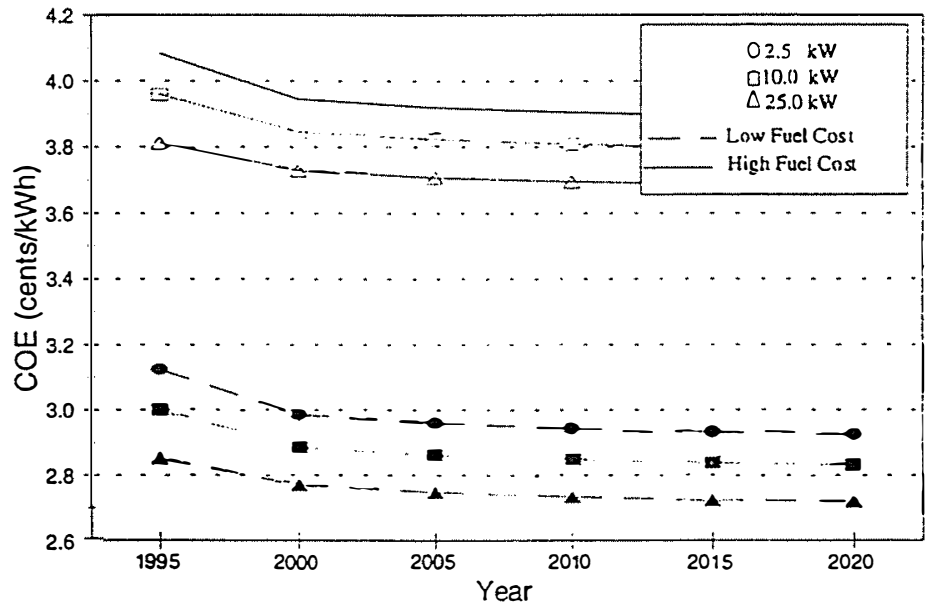

\begin{tabular}{|c|c|c|c|c|c|c|c|c|c|}
\hline \multirow[b]{2}{*}{ Year } & \multicolumn{9}{|c|}{ DATA SUMMARY TABLE } \\
\hline & $\begin{array}{l}\text { Units/Year } \\
\text { Produced }\end{array}$ & $\begin{array}{l}\text { Cuml } \\
\text { Production }\end{array}$ & $\begin{array}{c}\text { Scale } 1 \\
\text { Installed } \\
\text { Cost }(\$ / \mathrm{kW})\end{array}$ & $\begin{array}{l}\text { Units/Year } \\
\text { Produced }\end{array}$ & $\begin{array}{c}\text { Cuml } \\
\text { Production }\end{array}$ & $\begin{array}{c}\text { Scale 2 } \\
\text { Installed } \\
\text { Cost (\$/kW) }\end{array}$ & $\begin{array}{l}\text { Units/Year } \\
\text { Produced }\end{array}$ & $\begin{array}{c}\text { Cuml } \\
\text { Production }\end{array}$ & $\begin{array}{c}\text { Scale 3 } \\
\text { Installed } \\
\text { Cost }(\$ / k W)\end{array}$ \\
\hline 1995 & 0 & 0 & $\$ 1,188$ & $\overline{0}$ & 0 & $\$ 1,106$ & 0 & 0 & $\$ 1,011$ \\
\hline 2000 & 17 & 55 & $\$ 1,096$ & 10 & 32 & $\$ 1,033$ & 5 & 16 & $\$ 957$ \\
\hline 2005 & 12 & 114 & $\$ 1.080$ & 7 & 66 & $\$ 1,018$ & 3 & 33 & $\$ 943$ \\
\hline 2010 & 13 & 176 & $\$ 1,071$ & 7 & 102 & $\$ 1,009$ & 4 & 51 & $\$ 935$ \\
\hline 2015 & 13 & 243 & $\$ 1,064$ & 8 & 141 & $\$ 1,002$ & 4 & 71 & $\$ 929$ \\
\hline 2020 & 14 & 313 & $\$ 1.059$ & 8 & 181 & $\$ 997$ & 4 & 91 & $\$ 92$ \\
\hline
\end{tabular}

\begin{tabular}{|c|c|c|c|c|c|c|c|c|c|}
\hline \multirow[b]{3}{*}{ Year } & \multirow{3}{*}{$\begin{array}{c}\text { Scale 1 } \\
\text { Carrying } \\
\text { Chrg (s/kW) }\end{array}$} & \multirow{3}{*}{$\begin{array}{c}\text { Scale } 2 \\
\text { Carrying } \\
\text { Chrg }(\$ / k W)\end{array}$} & \multirow{3}{*}{$\begin{array}{c}\text { Scale } 3 \\
\text { Carrying } \\
\text { Chrg }(\$ / k W)\end{array}$} & \multicolumn{6}{|c|}{ Cost of Electricity Results (cents $/ \mathrm{kWh}$ ) } \\
\hline & & & & \multicolumn{2}{|c|}{ Scale 1} & \multicolumn{2}{|c|}{ Seale 2} & \multicolumn{2}{|c|}{ Seale 3} \\
\hline & & & & $\begin{array}{c}\text { High } \\
\text { Fuel Cost }\end{array}$ & $\begin{array}{c}\text { Low } \\
\text { Fuel Cost }\end{array}$ & $\begin{array}{c}\text { High } \\
\text { Fuel Cost }\end{array}$ & $\begin{array}{l}\text { Low } \\
\text { Fuel Cost }\end{array}$ & $\begin{array}{c}\text { High } \\
\text { Fuel Cost }\end{array}$ & $\begin{array}{l}\text { Low } \\
\text { Fuel Cost }\end{array}$ \\
\hline 1995 & $\$ 128$ & $\$ 120$ & $\$ 109$ & 4.08 & 3.12 & 3.96 & 3.00 & 3.81 & 2.85 \\
\hline 2000 & $\$ 118$ & $\$ 112$ & $\$ 103$ & 3.94 & 2.98 & 3.84 & 2.88 & 3.73 & 2.77 \\
\hline 2005 & $\$ 117$ & $\$ 110$ & $\$ 102$ & 3.92 & 2.96 & 3.82 & 2.86 & 3.71 & 2.75 \\
\hline 2010 & $\$ 116$ & $\$ 109$ & $\$ 101$ & 3.90 & 2.94 & 3.81 & 2.85 & 3.69 & 2.73 \\
\hline 2015 & $\$ 115$ & $\$ 108$ & $\$ 100$ & 3.89 & 2.93 & 3.80 & 2.84 & 3.68 & 2.72 \\
\hline 2020 & $\$ 114$ & $\$ 108$ & $\$ 100$ & 3.89 & 2.93 & 3.79 & 2.83 & 3.68 & 2.72 \\
\hline
\end{tabular}




\section{Direct-Fired Combustion Turbine Projections \\ Production Progress and Scale Based Cost Reductions LOW MARKET POTENTIAL SCENARIO}

\begin{tabular}{|c|c|c|c|}
\hline \multicolumn{4}{|c|}{$\begin{array}{l}K=\text { Assembly time } 1 \text { st unit } \\
X=\text { Cuml no. of units produced } \\
n=-\% \text { cost reduction per production doubling }\end{array}$} \\
\hline \multicolumn{4}{|l|}{ Production Parameters } \\
\hline Initial assembly time consta & nt for 1st un & $t(K)$ & 100 \\
\hline Percent decrease for doubli & ing in cuml $p$ & oduction & $-2 \%$ \\
\hline Variable Cost as \% of Total & Manufactur & ng Cost & $99.9 \%$ \\
\hline \multicolumn{4}{|l|}{ InitialCost/Size Parameters } \\
\hline Scaling Data Point (Plant Si & ize, kW) & & $5,800.0$ \\
\hline Scaling Data Point (First Un & it Cost) & & $\$ 7,250,000$ \\
\hline Refurbishment Adjustment $F$ & Factor & & 1.00 \\
\hline Scaling Exponent & & & $87 \%$ \\
\hline Plant Capacity Factor & & & $80 \%$ \\
\hline & $\begin{array}{c}\text { Plant } \\
\text { Size (kW) }\end{array}$ & $\begin{array}{c}\text { First Unit } \\
\text { Cost }(\$ / k W)\end{array}$ & $\begin{array}{c}\text { kWh per } \\
\text { Year }\end{array}$ \\
\hline Scale 1 & $5,800.0$ & $\$ 1,250$ & $40,646,400$ \\
\hline Scale 2 & $10,000.0$ & $\$ 1,165$ & $70,080,000$ \\
\hline Scale 3 & 20.000 .0 & $\$ 1,064$ & $140,160,000$ \\
\hline \multicolumn{2}{|l|}{ e\&M costs (cents/kWhr) } & High & Low \\
\hline \multicolumn{2}{|l|}{ O\&M w/o Fuel Cost } & 0.563 & 0.563 \\
\hline \multicolumn{2}{|l|}{ Fuel Costs } & 1.690 & 0.730 \\
\hline \multicolumn{2}{|l|}{ Transmission Costs } & 0.000 & 0.000 \\
\hline \multicolumn{2}{|l|}{ Total O\&M Costs } & $\overline{2.253}$ & $\overline{1.293}$ \\
\hline \multicolumn{4}{|c|}{ Carrying Charge Input Summary } \\
\hline \multirow{2}{*}{\multicolumn{2}{|c|}{$\begin{array}{l}\text { Debt Interest Rate } \\
\text { Debt Fraction }\end{array}$}} & $12.00 \%$ & \\
\hline & & $75.00 \%$ & \\
\hline & $22.00 \%$ & \\
\hline $\begin{array}{l}\text { Equity Cost } \\
\text { Equity Fraction }\end{array}$ & & $25.00 \%$ & \\
\hline \multicolumn{2}{|l|}{ Construction Escalation Rate } & $4.50 \%$ & \\
\hline \multicolumn{2}{|l|}{ Construction Time } & 0.5 & \\
\hline \multicolumn{2}{|l|}{ Book Life } & 30 & \\
\hline \multicolumn{2}{|l|}{ Depreciation Life } & 1 & \\
\hline \multicolumn{2}{|l|}{ Additional Capital Charges } & 0 & \\
\hline \multicolumn{2}{|l|}{ Property Tax \& Insurance } & $2.00 \%$ & \\
\hline \multicolumn{2}{|l|}{ TaxRate } & $40.00 \%$ & \\
\hline
\end{tabular}

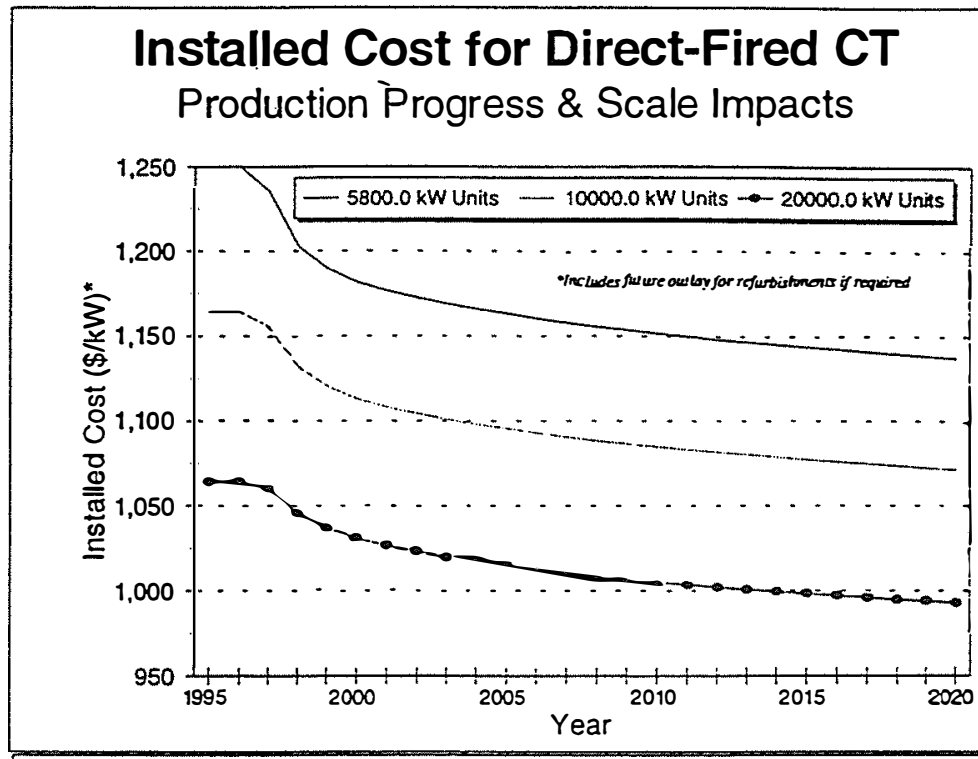

\section{COST OF ELECTRICITY ANALYSIS}

Direct-Fired CT

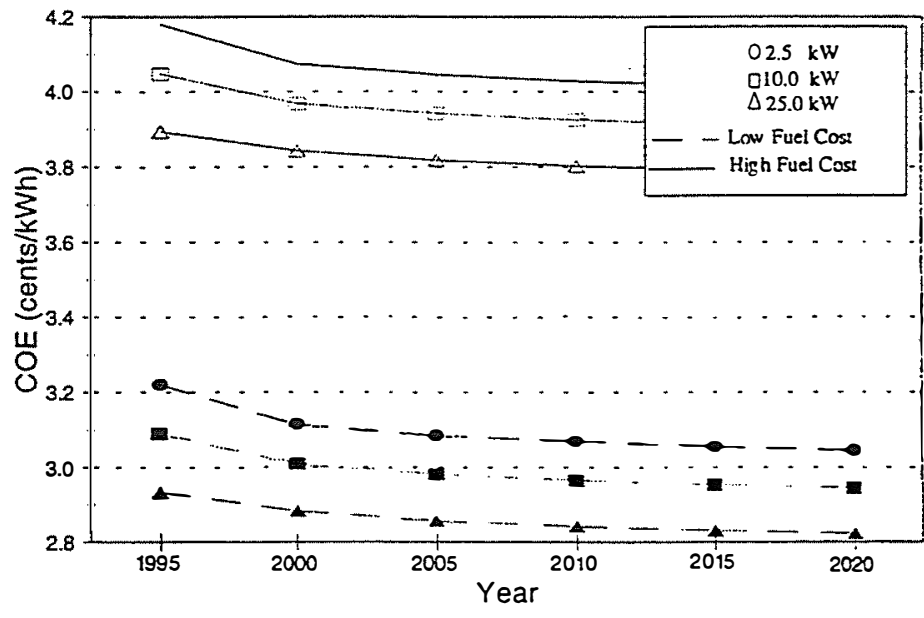

\begin{tabular}{|c|c|c|c|c|c|c|c|c|c|}
\hline \multirow[b]{2}{*}{ Year } & \multicolumn{9}{|c|}{ DATA SUMMARY TABLE } \\
\hline & $\begin{array}{l}\text { Units Yyear } \\
\text { Produced }\end{array}$ & $\begin{array}{c}\text { Cuml } \\
\text { Production }\end{array}$ & $\begin{array}{c}\text { Scale } 1 \\
\text { Installed } \\
\text { Cost }(\$ / k W)\end{array}$ & $\begin{array}{l}\text { Units/Year } \\
\text { Produced }\end{array}$ & $\begin{array}{c}\text { Cuml } \\
\text { Production }\end{array}$ & $\begin{array}{c}\text { Scale } 2 \\
\text { installed. } \\
\text { Cost }(\$ / k W)\end{array}$ & $\begin{array}{l}\text { Units/Year } \\
\text { Produced }\end{array}$ & $\begin{array}{c}\text { Cuml } \\
\text { Production }\end{array}$ & $\begin{array}{c}\text { Scale } 3 \\
\text { Installed } \\
\text { Cost (S/kW) }\end{array}$ \\
\hline 1995 & 0 & 0 & $\$ 1,250$ & 0 & 0 & $\$ 1,165$ & 0 & 0 & $\$ 1,064$ \\
\hline 2000 & 5 & 17 & $\$ 1,181$ & 3 & 10 & $\$ 1,113$ & 1 & 5 & $\$ 1,031$ \\
\hline 2005 & 4 & 37 & $\$ 1,163$ & 2 & 21 & $\$ 1,095$ & 1 & 11 & $\$ 1,015$ \\
\hline 2010 & 5 & 61 & $\$ 1,151$ & 3 & 35 & $\$ 1,084$ & 1 & 18 & $\$ 1,005$ \\
\hline 2015 & 5 & 86 & $\$ 1,144$ & 3 & 50 & $\$ 1.077$ & 1 & 25 & $\$ 998$ \\
\hline 2020 & 5 & 113 & $\$ 1.137$ & 3 & 66 & $\$ 1,071$ & 2 & 33 & $\$ 993$ \\
\hline
\end{tabular}

\begin{tabular}{|c|c|c|c|c|c|c|c|c|c|}
\hline \multirow[b]{3}{*}{ Year } & \multirow{3}{*}{$\begin{array}{c}\text { Scale 1 } \\
\text { Carrying } \\
\text { Chrg }(\$ / \mathrm{kW})\end{array}$} & \multirow{3}{*}{$\begin{array}{c}\text { Scale 2 } \\
\text { Carrying } \\
\text { Chrg }(\$ / \mathrm{kW})\end{array}$} & \multirow{3}{*}{$\begin{array}{c}\text { Scale } 3 \\
\text { Carrying } \\
\text { Chrg }(\$ / k W)\end{array}$} & \multicolumn{6}{|c|}{ Cost of Electricity Results (cents/kWh) } \\
\hline & & & & \multicolumn{2}{|c|}{ Scale 1} & \multicolumn{2}{|c|}{ Scale 2} & \multicolumn{2}{|c|}{ Scale 3} \\
\hline & & & & $\begin{array}{l}\text { High } \\
\text { Fuel Cost }\end{array}$ & $\begin{array}{l}\text { Low } \\
\text { Fuel Cost }\end{array}$ & $\begin{array}{c}\text { High } \\
\text { Fuel Cost }\end{array}$ & $\begin{array}{l}\text { Low } \\
\text { Fuel Cost }\end{array}$ & $\begin{array}{l}\text { High } \\
\text { Fuel Cost }\end{array}$ & $\begin{array}{l}\text { Low } \\
\text { Fuel Cost }\end{array}$ \\
\hline 1995 & $\$ 135$ & $\$ 126$ & $\$ 115$ & 4.18 & 3.22 & 4.05 & 3.09 & 3.89 & 2.93 \\
\hline 2000 & $\$ 128$ & $\$ 120$ & $\$ 111$ & 4.07 & 3.11 & 3.97 & 3.01 & 3.84 & 2.88 \\
\hline 2005 & $\$ 126$ & $\$ 118$ & $\$ 110$ & 4.05 & 3.09 & 3.94 & 2.98 & 3.82 & 2.86 \\
\hline 2010 & $\$ 124$ & $\$ 117$ & $\$ 109$ & 4.03 & 3.07 & 3.92 & 2.96 & 3.80 & 2.84 \\
\hline 2015 & $\$ 124$ & $\$ 116$ & $\$ 108$ & 4.02 & 3.06 & 3.91 & 2.95 & 3.79 & 2.83 \\
\hline 2020 & $\$ 123$ & $\$ 116$ & $\$ 107$ & 4.01 & 3.05 & 3.90 & 2.94 & 3.78 & 2.82 \\
\hline
\end{tabular}




\section{Fuel Cell Projections \\ Production Progress and Scale Based Cost Reductions HIGH MARKET POTENTIAL SCENARIO}

Leaming Curve Equation. $Y=K X^{\wedge} n$

$K=$ Assembly time 1 st unit

$X=$ Cuml no. of units produced

$n=-\%$ cost reduction per production doubling

\section{Production Parameters}

Initial assembly time constant for 1 st unit $(K)$

Percent decrease for doubling in cuml production

Variable Cost as \% of Total Manufacturing Cost

Initial Cost/Size Parameters

Scaling Data Point (Plant Size, kW)

Scaling Data Point (First Unit Cost)

Refurbishment Adjustment Factor

Scaling Exponent

Plant Capacity Factor

\begin{tabular}{lrrr} 
& $\begin{array}{c}\text { Plant } \\
\text { Size }(\mathrm{kW})\end{array}$ & $\begin{array}{c}\text { First Unit } \\
\text { Cost }(\$ / \mathrm{kW})\end{array}$ & $\begin{array}{c}\text { kWh per } \\
\text { Year }\end{array}$ \\
\cline { 2 - 4 } Scale 1 & $2,850.0$ & $\$ 4,690$ & $21,470,760$ \\
Scale 2 & $6,000.0$ & $\$ 4,690$ & $45,201,600$ \\
Scale 3 & $10,000.0$ & $\$ 4,690$ & $75,336,000$ \\
& & & \\
Q\&M Costs (cents/kWhr) & & High & Low \\
O\&M w/o Fuel Cost & & 0.466 & 0.466 \\
Fuel Costs & & 1.240 & 0.540 \\
Transmission Costs & & 0.000 & $\underline{000}$ \\
Total O\&M Costs & & 1.706 & 1.006
\end{tabular}

Carnuing Charge Input Summary

\section{Debt interest Rate \\ Debt Fraction}

$12.00 \%$

Equity Cost

Equity Fraction

Construction Escalation Rate

$75.00 \%$

$22.00 \%$

$25.00 \%$

$4.50 \%$

Construction Time

0.5

Book Life

Depreciation Life

Additional Capital Charges

Property Tax \& Insurance

Tax Rate

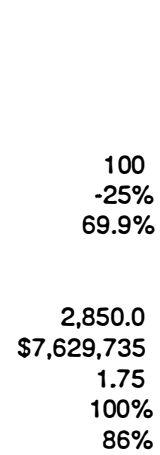

00

$-25 \%$

850.0

1.75

$86 \%$

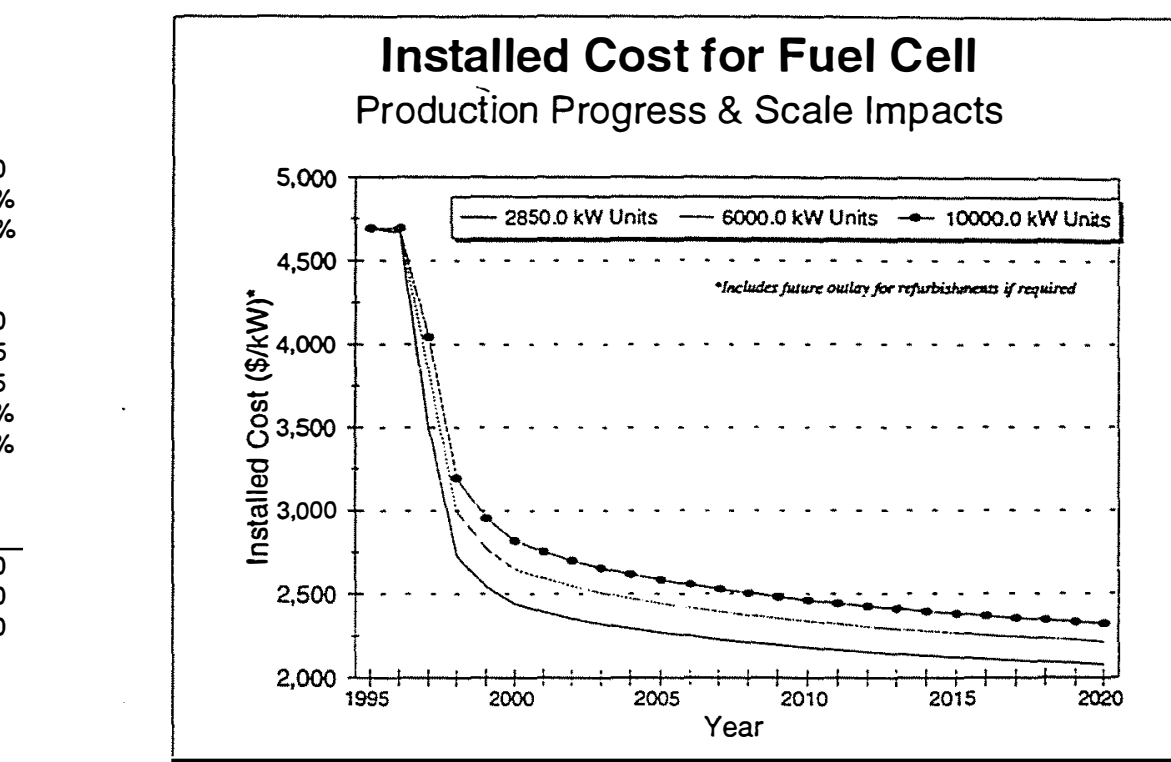

COST OF ELECTRICITY ANALYSIS

Fuel Cell

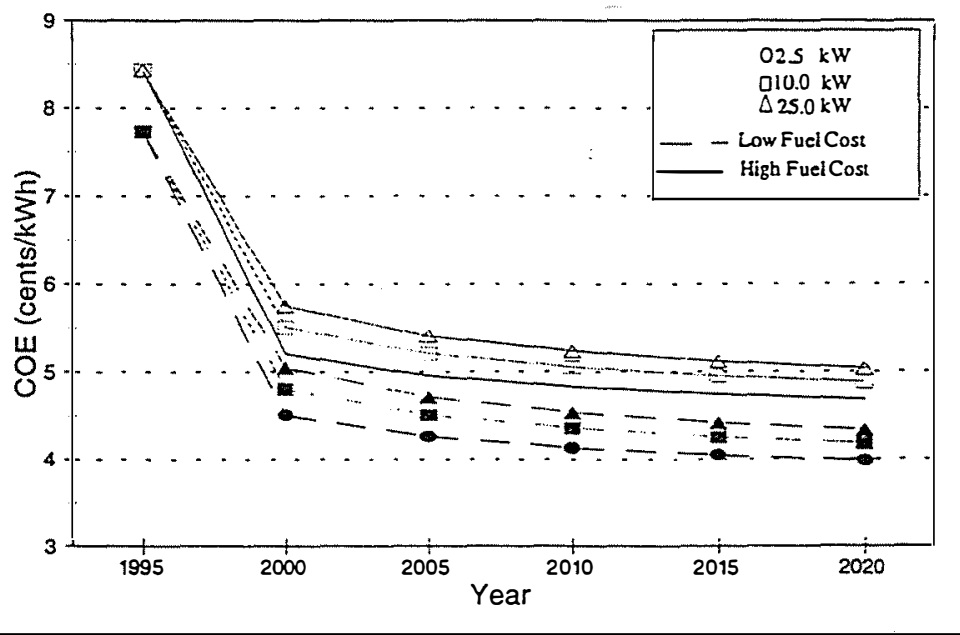

\begin{tabular}{|c|c|c|c|c|c|c|c|c|c|}
\hline \multirow[b]{2}{*}{ Year } & \multicolumn{9}{|c|}{ DATA SUMMARY TABLE } \\
\hline & $\begin{array}{l}\text {-Units/Year } \\
\text { Produced }\end{array}$ & $\begin{array}{c}\text { Cuml } \\
\text { Production }\end{array}$ & $\begin{array}{c}\text { Scale } 1 \\
\text { Installed } \\
\text { Cost }(\$ / \mathrm{kW})\end{array}$ & $\begin{array}{l}\text { Units/Year } \\
\text { Produced }\end{array}$ & $\begin{array}{c}\text { Cuml } \\
\text { Production }\end{array}$ & $\begin{array}{c}\text { Scale } 2 \\
\text { Installed } \\
\text { Cost }(\$ / k W)\end{array}$ & $\begin{array}{l}\text { Units/Year } \\
\text { Produced }\end{array}$ & $\begin{array}{c}\text { Cuml } \\
\text { Production }\end{array}$ & $\begin{array}{c}\text { Scale } 3 \\
\text { Installed } \\
\text { Cost }(\$ / k W)\end{array}$ \\
\hline 1995 & 0 & 0 & $\$ 4,690$ & 0 & 0 & $\$ 4,690$ & 0 & 0 & $\$ 4,690$ \\
\hline 2000 & 32 & 103 & $\$ 2,440$ & 15 & 49 & $\$ 2,650$ & 9 & 29 & $\$ 2,819$ \\
\hline 2005 & 22 & 215 & $\$ 2.268$ & 11 & 102 & $\$ 2,443$ & 6 & 61 & $\$ 2,584$ \\
\hline 2010 & 24 & 334 & $\$ 2,179$ & 11 & 159 & $\$ 2,336$ & 7 & 95 & $\$ 2,462$ \\
\hline 2015 & 25 & 461 & $\$ 2,119$ & 12 & 219 & $\$ 2,264$ & 7 & 131 & $\$ 2,380$ \\
\hline 2020 & 26 & 592 & $\$ 2.076$ & 13 & 281 & $\$ 2.212$ & 8 & 169 & $\$ 2.321$ \\
\hline
\end{tabular}

\begin{tabular}{|c|c|c|c|c|c|c|c|c|c|}
\hline \multirow[b]{3}{*}{ Year } & \multirow{3}{*}{$\begin{array}{c}\text { Scale 1 } \\
\text { Carrying } \\
\text { Chrg (s/kW) }\end{array}$} & \multirow{3}{*}{$\begin{array}{c}\text { Scale } 2 \\
\text { Carrying } \\
\text { Chrg (S/kW) }\end{array}$} & \multirow{3}{*}{$\begin{array}{c}\text { Scale } 3 \\
\text { Carrying } \\
\text { Chrg (\$s/kW) }\end{array}$} & \multicolumn{6}{|c|}{ Cost of Electricity Results (cents/kWh) } \\
\hline & & & & \multicolumn{2}{|c|}{ Scale 1 } & \multicolumn{2}{|c|}{ Scale 2} & \multicolumn{2}{|c|}{ Scale 3} \\
\hline & & & & $\begin{array}{c}\text { High } \\
\text { Fuel Cost }\end{array}$ & $\begin{array}{c}\text { Low } \\
\text { Fuel Cost }\end{array}$ & $\begin{array}{c}\text { High } \\
\text { Fuel Cost }\end{array}$ & $\begin{array}{c}\text { Low } \\
\text { Fuel Cost }\end{array}$ & $\begin{array}{c}\text { High } \\
\text { Fuel Cost }\end{array}$ & $\begin{array}{l}\text { Low } \\
\text { Fuel Cost }\end{array}$ \\
\hline 1995 & $\$ 507$ & $\$ 507$ & $\$ 507$ & 8.43 & 7.73 & 8.43 & 7.73 & 8.43 & 7.73 \\
\hline 2000 & $\$ 264$ & $\$ 286$ & $\$ 305$ & 5.20 & 4.50 & 5.51 & 4.81 & 5.75 & 5.05 \\
\hline 2005 & $\$ 245$ & $\$ 264$ & $\$ 279$ & 4.96 & 4.26 & 5.21 & 4.51 & 5.41 & 4.71 \\
\hline 2010 & $\$ 235$ & $\$ 252$ & $\$ 266$ & 4.83 & 4.13 & 5.06 & 4.36 & 5.24 & 4.54 \\
\hline 2015 & $\$ 229$ & $\$ 245$ & $\$ 257$ & 4.75 & 4.05 & 4.95 & 4.25 & 5.12 & 4.42 \\
\hline 2020 & $\$ 224$ & $\$ 239$ & $\$ 251$ & 4.68 & 3.98 & 4.88 & 4.18 & 5.03 & 4.33 \\
\hline
\end{tabular}




\section{Fuel Cell Projections \\ Production Progress and Scale Based Cost Reductions LOW MARKET POTENTIAL SCENARIO}

Learning Curve Equation. $Y=K X^{\wedge} n$

$K=$ Assembly time 1st unit

$X=$ Cuml no. of units produced

$n=-\%$ cost reduction per production doubling

Production Parameters

Initial assembly time constant for 1 st unit (K)

Percent decrease for doubling in cuml production

Variable Cost as \% of Total Manufacturing Cost

Initial Cost/Size Parameters

Scaling Data Point (Plant Size, kW)

Scaling Data Point (First Unit Cost)

Refurbishment Adjustment Factor

Scaling Exponent

Plant Capacity Factor

\begin{tabular}{lrrc} 
& $\begin{array}{c}\text { Plant } \\
\text { Size }(\mathrm{kW})\end{array}$ & $\begin{array}{c}\text { First Unit } \\
\text { Cost }(\mathbf{S} / \mathrm{kW})\end{array}$ & $\begin{array}{c}\text { kWh per } \\
\text { Year }\end{array}$ \\
\cline { 2 - 4 } Scale 1 & $2,850.0$ & $\$ 4,937$ & $21,470,760$ \\
Scale 2 & $6,000.0$ & $\$ 4.937$ & $45,201,600$ \\
& $10,000.0$ & $\$ 4,937$ & $75,336,000$ \\
O\&M Costs (cents/kWhr) & & High & Low \\
\hline O\&M w/o Fuel Cost & & 0.466 & 0.466 \\
Fuel Costs & & 1.240 & 0.540 \\
Transmission Costs & & $\underline{2.000}$ & $\frac{0.000}{1.006}$ \\
Total O\&M Costs & & 1.706 &
\end{tabular}

Carrying Charge Input Summary

Debt Interest Rate $\quad 12.00 \%$

Debt Fraction $\quad 75.00 \%$

Equity Cost $\quad 22.00 \%$

Equity Fraction $\quad 25.00 \%$

Construction Escalation Rate $\quad 4.50 \%$

Construction Time

Book Life

Depreciation Life

Additional Capital Charges

Property Tax \& Insurance

TaxRate

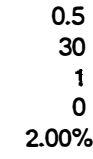

$40.00 \%$

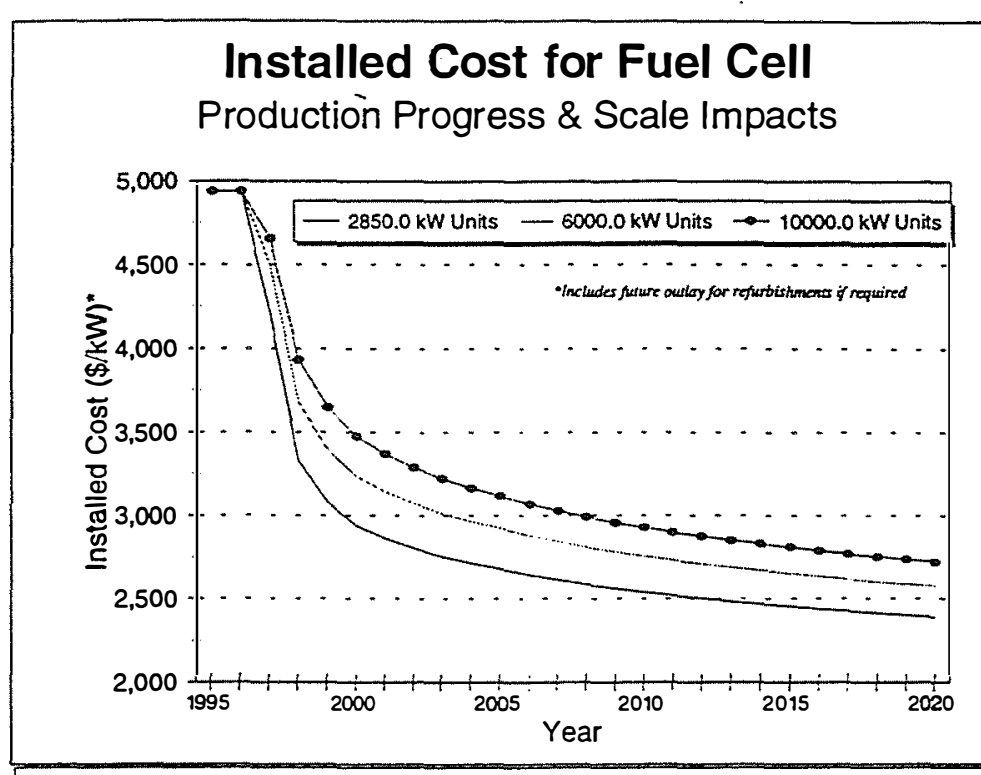

COST OF ELECTRICITY ANALYSIS

Fuel Cell

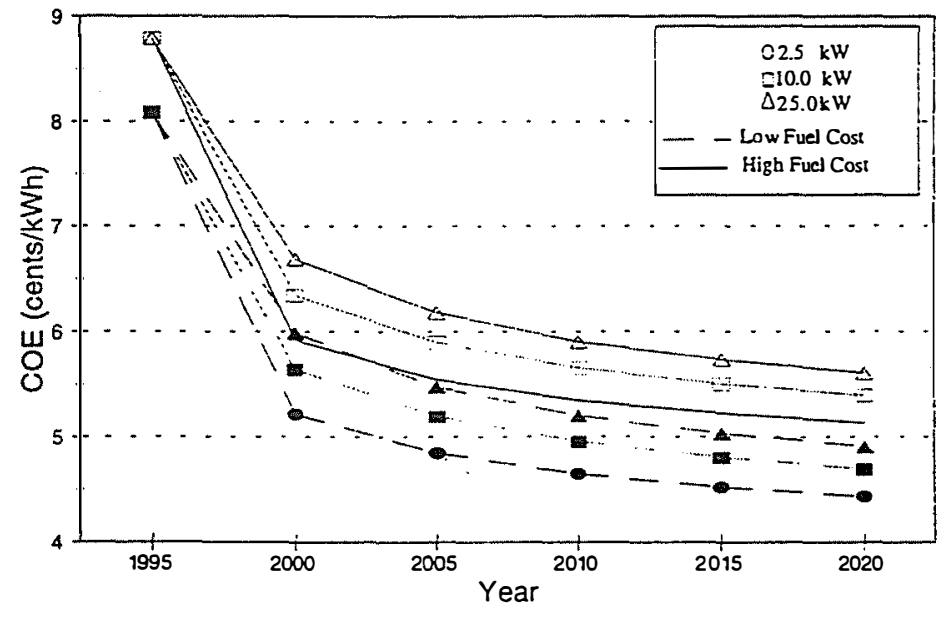

\begin{tabular}{|c|c|c|c|c|c|c|c|c|c|}
\hline \multirow[b]{2}{*}{ Year } & \multicolumn{9}{|c|}{ DATA SUMMARY TABLE } \\
\hline & $\begin{array}{l}\text { Units Year } \\
\text { Produced }\end{array}$ & $\begin{array}{l}\text { Cuml } \\
\text { Production }\end{array}$ & $\begin{array}{c}\text { Scale } 1 \\
\text { Installed } \\
\text { Cost }(\$ / k W)\end{array}$ & $\begin{array}{l}\text { Units/Year } \\
\text { Produced }\end{array}$ & $\begin{array}{l}\text { Cuml } \\
\text { Production }\end{array}$ & $\begin{array}{c}\text { Scale 2 } \\
\text { Installed } \\
\text { Cost (\$/kW) }\end{array}$ & $\begin{array}{l}\text { Units } / e a r \\
\text { Produced }\end{array}$ & $\begin{array}{c}\text { Cuml } \\
\text { Production }\end{array}$ & $\begin{array}{c}\text { Scale 3 } \\
\text { Installed } \\
\text { Cost (s/kW) }\end{array}$ \\
\hline 1995 & 0 & 0 & $\$ 4,937$ & 0 & 0 & $\$ 4,937$ & 0 & 0 & $\$ 4,937$ \\
\hline 2000 & 10 & 32 & $\$ 2,938$ & 4 & 15 & $\$ 3,235$ & 3 & 9 & $\$ 3,473$ \\
\hline 2005 & 8 & 70 & $\$ 2,679$ & 4 & 33 & $\$ 2,923$ & 2 & 20 & $\$ 3,119$ \\
\hline 2010 & 9 & 115 & $\$ 2.539$ & 4 & 55 & $\$ 2,754$ & 3 & 33 & $\$ 2,927$ \\
\hline 2015 & 9 & 162 & $\$ 2,453$ & 4 & $\pi$ & $\$ 2,651$ & 3 & 46 & $\$ 2,809$ \\
\hline 2020 & 10 & 214 & $\$ 2.388$ & 5 & 102 & $\$ 2.573$ & 3 & 61 & $\$ 2.721$ \\
\hline
\end{tabular}

\begin{tabular}{|c|c|c|c|c|c|c|c|c|c|}
\hline \multirow[b]{3}{*}{ Year } & \multirow{3}{*}{$\begin{array}{c}\text { Scale 1 } \\
\text { Carrying } \\
\text { Chrg }(\$ / k W)\end{array}$} & \multirow{3}{*}{$\begin{array}{c}\text { Scale } 2 \\
\text { Carrying } \\
\text { Chrg }(\$ / \mathrm{kW})\end{array}$} & \multirow{3}{*}{$\begin{array}{c}\text { Scale } 3 \\
\text { Carrying } \\
\text { Chrg }(5 / \mathrm{kW})\end{array}$} & \multicolumn{6}{|c|}{ Cost of Electricity Results (cents/kWh) } \\
\hline & & & & \multicolumn{2}{|c|}{ Scale 1 } & \multicolumn{2}{|c|}{ Seale 2} & \multicolumn{2}{|c|}{ Seale 3} \\
\hline & & & & $\begin{array}{c}\text { High } \\
\text { Fuel Cost }\end{array}$ & $\begin{array}{l}\text { Low } \\
\text { Fuel Cost }\end{array}$ & $\begin{array}{c}\text { High } \\
\text { Fuel Cost }\end{array}$ & $\begin{array}{l}\text { Low } \\
\text { Fuel Cost }\end{array}$ & $\begin{array}{c}\text { High } \\
\text { Fuel Cost }\end{array}$ & $\begin{array}{l}\text { Low } \\
\text { Fuel Cost }\end{array}$ \\
\hline 1995 & $\$ 533$ & $\$ 533$ & $\$ 533$ & 8.79 & 8.09 & 8.79 & 8.09 & 8.79 & 8.09 \\
\hline 2000 & $\$ 317$ & $\$ 349$ & $\$ 375$ & 5.92 & 5.22 & 6.35 & 5.65 & 6.69 & 5.99 \\
\hline 2005 & $\$ 289$ & $\$ 316$ & $\$ 337$ & 5.55 & 4.85 & 5.90 & 5.20 & 6.18 & 5.48 \\
\hline 2010 & $\$ 274$ & $\$ 298$ & $\$ 316$ & 5.35 & 4.65 & 5.66 & 4.96 & 5.90 & 5.20 \\
\hline 2015 & $\$ 265$ & $\$ 286$ & $\$ 303$ & 5.22 & 4.52 & 5.51 & 4.81 & 5.73 & 5.03 \\
\hline 2020 & $\$ 258$ & $\$ 278$ & $\$ 294$ & 5.13 & 4.43 & 5.40 & 4.70 & 5.61 & 4.91 \\
\hline
\end{tabular}




\section{BIGCC Projections \\ Production Progress and Scale Based Cost Reductions HIGH MARKET POTENTIAL SCENARIO}

Learning Curve Equation. $Y=K X^{\wedge} n$

$\mathrm{K}=$ Assembly time 1 st unit

$\mathrm{X}=$ Cuml no. of units produced

$n=-\%$ cost reduction per production doubling

Production Parameters

Initial assembly time constant for 1 st unit (K)

Percent decrease for doubling in cuml production

Variable Cost as \% of Total Manufacturing Cost

Initial Cost/Size Parameters

Scaling Data Point (Plant Size, kW)

Scaling Data Point (First Unit Cost)

Refurbishment Adjustment Factor

Scaling Exponent

Plant Capacity Factor

\begin{tabular}{lrrr} 
& $\begin{array}{c}\text { Plant } \\
\text { Size }(\mathbf{k W})\end{array}$ & $\begin{array}{c}\text { First Unit } \\
\text { Cost }(\mathbf{\$} / \mathbf{k W})\end{array}$ & $\begin{array}{c}\text { kWh per } \\
\text { Year }\end{array}$ \\
\cline { 2 - 4 } Scale 1 & $20,000.0$ & $\$ 1,359$ & $150,672,000$ \\
Scale 2 & $40,000.0$ & $\$ 1,313$ & $301,344,000$ \\
Scale 3 & $80,000.0$ & $\$ 1,268$ & $602,688,000$
\end{tabular}

\begin{tabular}{lll} 
O\&M Costs (cents/kWhr) & Hiah & Low \\
\hline O\&M w/o Fuel Cost & 0.693 & 0.693 \\
Fuel Costs & 1.200 & 0.520 \\
Transmission Costs & $\frac{2.00}{1.893}$ & 0.000 \\
Total O\&M Costs & 1.213
\end{tabular}

Carrying Charge Input Summary

Debt Interest Rate

$12.00 \%$

Debt Fraction

$75.00 \%$

Equity Cost

$22.00 \%$

Equity Fraction

$25.00 \%$

Construction Escalation Rate

$4.50 \%$

Construction Time

Book Life

Depreciation Life

Additional Capital Charges

Property Tax \& Insurance

Tax Rate

\begin{tabular}{r} 
\\
\\
100 \\
$-20 \%$ \\
$33.2 \%$ \\
\\
\\
$122,000.0$ \\
$\$ 151,481,300$ \\
1.00 \\
$95 \%$ \\
$86 \%$ \\
kWh per \\
Year \\
\hline $150,672,000$ \\
$301,344,000$ \\
$602,688,000$ \\
Low \\
\hline 0.693 \\
0.520 \\
$\frac{0.000}{1.213}$
\end{tabular}

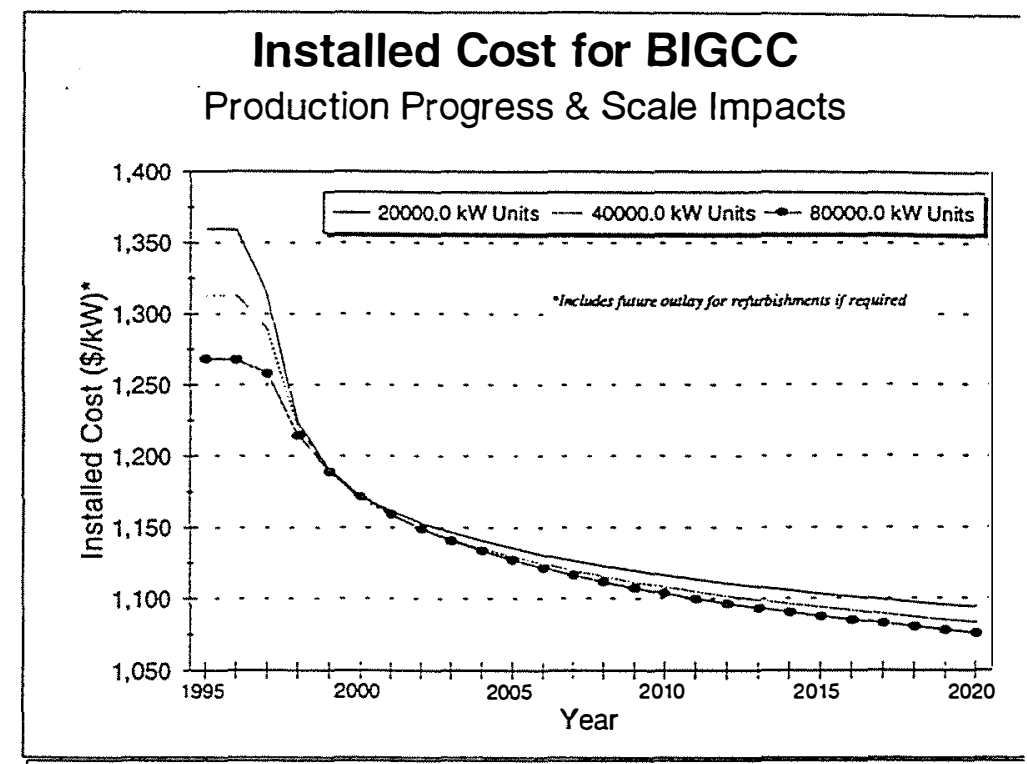

\section{COST OF ELECTRICITY ANALYSIS BIGCC}

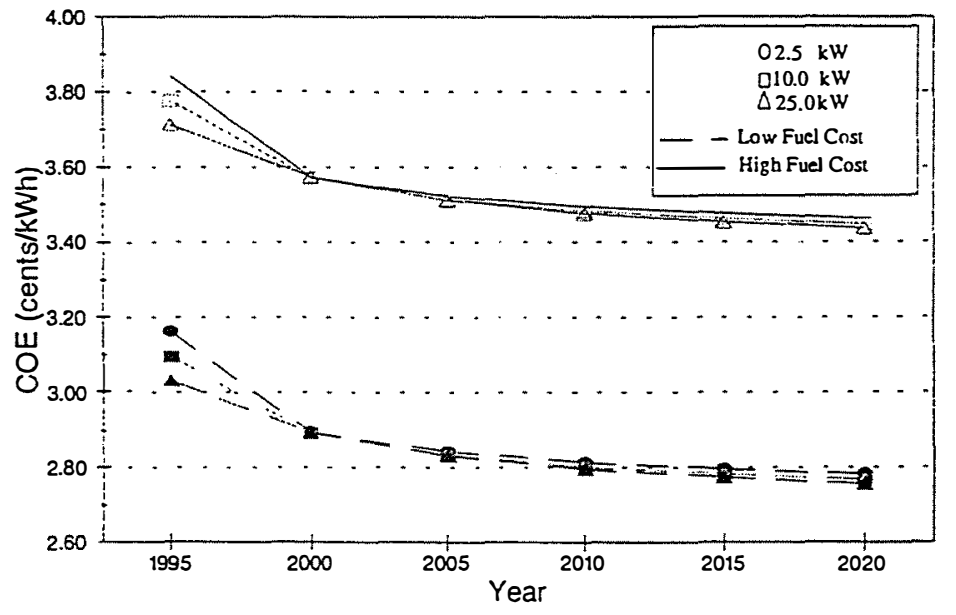

\begin{tabular}{|c|c|c|c|c|c|c|c|c|c|}
\hline \multirow[b]{2}{*}{ Year } & \multicolumn{9}{|c|}{ DATA SUMMARY TABLE } \\
\hline & $\begin{array}{l}\text { Units/Year } \\
\text { Produced }\end{array}$ & $\begin{array}{c}\text { Cuml } \\
\text { Production }\end{array}$ & $\begin{array}{c}\text { Scale } 1 \\
\text { Installed } \\
\text { Cost (\$/kW) }\end{array}$ & $\begin{array}{l}\text { Units/Year } \\
\text { Produced }\end{array}$ & $\begin{array}{c}\text { Cuml } \\
\text { Production }\end{array}$ & $\begin{array}{c}\text { Scale 2 } \\
\text { Installed } \\
\text { Cost }(\$ / k W)\end{array}$ & $\begin{array}{l}\text { Units/Year } \\
\text { Produced }\end{array}$ & $\begin{array}{c}\text { Cuml } \\
\text { Production }\end{array}$ & $\begin{array}{c}\text { Scale 3 } \\
\text { Installed } \\
\text { Cost }(\$ / k W)\end{array}$ \\
\hline 1995 & 0 & 0 & $\$ 1,359$ & 0 & 0 & $\$ 1,313$ & 0 & 0 & $\$ 1,268$ \\
\hline 2000 & 4 & 15 & $\$ 1,171$ & 2 & 7 & $\$ 1,169$ & 1 & 4 & $\$ 1,171$ \\
\hline 2005 & 3 & 31 & $\$ 1,135$ & 2 & 15 & $\$ 1,130$ & 1 & 8 & $\$ 1,127$ \\
\hline 2010 & 3 & 48 & $\$ 1,116$ & 2 & 24 & $\$ 1,108$ & 1 & 12 & $\$ 1,104$ \\
\hline 2015 & 4 & 66 & $\$ 1,103$ & 2 & 33 & $\$ 1,094$ & 1 & 16 & $\$ 1,088$ \\
\hline 2020 & 4 & 84 & $\$ 1.094$ & 2 & 42 & $\$ 1.083$ & 1 & 21 & $\$ 1.076$ \\
\hline
\end{tabular}

\begin{tabular}{|c|c|c|c|c|c|c|c|c|c|}
\hline \multirow[b]{3}{*}{ Year } & \multirow{3}{*}{$\begin{array}{c}\text { Scale } 1 \\
\text { Carrying } \\
\text { Chrg }(\$ / k W)\end{array}$} & \multirow{3}{*}{$\begin{array}{c}\text { Scale } 2 \\
\text { Carrying } \\
\text { Chrg }(\$ / k W)\end{array}$} & \multirow{3}{*}{$\begin{array}{c}\text { Scale } 3 \\
\text { Carrying } \\
\text { Chrg (S/kW) }\end{array}$} & \multicolumn{6}{|c|}{ Cost of Electricity Results (cents/kWh) } \\
\hline & & & & Seal & & 58 & & & \\
\hline & & & & $\begin{array}{c}\text { High } \\
\text { Fuel Cost }\end{array}$ & $\begin{array}{c}\text { Low } \\
\text { Fuel Cost }\end{array}$ & $\begin{array}{l}\text { High } \\
\text { Fuel Cost }\end{array}$ & $\begin{array}{l}\text { Low } \\
\text { Fuel Cost }\end{array}$ & $\begin{array}{l}\text { High } \\
\text { Fuel Cost }\end{array}$ & $\begin{array}{l}\text { Low } \\
\text { Fuel Cost }\end{array}$ \\
\hline 1995 & $\$ 147$ & $\$ 142$ & $\$ 137$ & 3.84 & 3.16 & 3.78 & 3.10 & 3.71 & 3.03 \\
\hline 2000 & $\$ 127$ & $\$ 126$ & $\$ 127$ & 3.57 & 2.89 & 3.57 & 2.89 & 3.57 & 2.89 \\
\hline 2005 & $\$ 123$ & $\$ 122$ & $\$ 122$ & 3.52 & 2.84 & .3 .51 & 2.83 & 3.51 & 2.83 \\
\hline 2010 & $\$ 121$ & $\$ 120$ & $\$ 119$ & 3.49 & 2.81 & 3.48 & 2.80 & 3.48 & 2.80 \\
\hline 2015 & $\$ 119$ & $\$ 118$ & $\$ 118$ & 3.48 & 2.80 & 3.46 & 2.78 & 3.45 & 2.77 \\
\hline 2020 & $\$ 118$ & $\$ 117$ & $\$ 116$ & 3.46 & 2.78 & 3.45 & 2.77 & 3.44 & 2.76 \\
\hline
\end{tabular}




\section{BIGCC Projections \\ Production Progress and Scale Based Cost Reductions \\ LOW MARKET POTENTIAL SCENARIO}

Leaming Cunve Equation. $Y=K X^{\wedge} n$

$\mathrm{K}=$ Assembly time 1 st unit

$X=$ Cuml no. of units produced

$n=-\%$ cost reduction per production doubling

Broduction Parameters

Initial assembly time constant for 1 st unit (K)

Percent decrease for doubling in cuml production

Variable Cost as \% of Total Manufacturing Cost

Initial Cost / Size Parameters

Scaling Data Point (Plant Size, kW)

Scaling Data Point (First Unit Cost)

Refurbishment Adjustment Factor

Scaling Exponent

Plant Capacity Factor

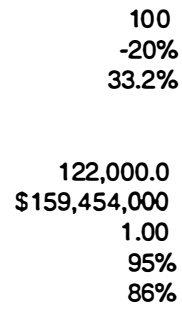

\begin{tabular}{lrrr} 
& $\begin{array}{c}\text { Plant } \\
\text { Size }(\mathrm{kW})\end{array}$ & $\begin{array}{c}\text { First Unit } \\
\text { Cost }(\$ / \mathrm{kW})\end{array}$ & $\begin{array}{c}\text { kWh per } \\
\text { Year }\end{array}$ \\
\cline { 2 - 4 } Scale 1 & $20,000.0$ & $\$ 1,431$ & $150,672,000$ \\
Scale 2 & $40,000.0$ & $\$ 1,382$ & $301,344,000$ \\
Scale 3 & $80,000.0$ & $\$ 1,335$ & $602,688,000$
\end{tabular}

O\&M Costs (cents/kWhr)

O\&M w/o Fuel Cost

\begin{tabular}{ll} 
High & Low \\
0.693 & 0.693 \\
1.200 & 0.520 \\
0.000 & 0.000 \\
\hline 1.893 & 1.213
\end{tabular}

Transmission Costs

Total O\&M Costs

$12.00 \%$

Carring Charge Input Summary

Debt Interest Rate

$75.00 \%$

$22.00 \%$

Equity Cost

$25.00 \%$

Construction Escalation Rate $\quad 4.50 \%$

Construction Time

0.5

Depreciation Life

Additional Capital Charges

Property Tax \& Insurance

Tax Rate

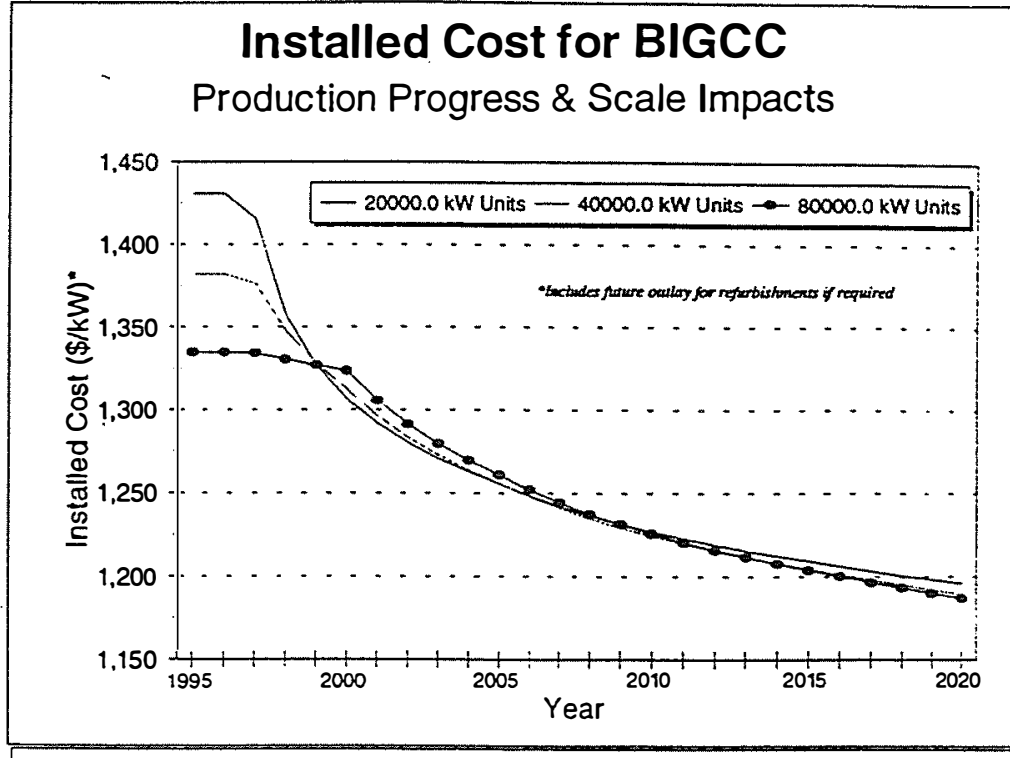

\section{COST OF ELECTRICITY ANALYSIS} BIGCC

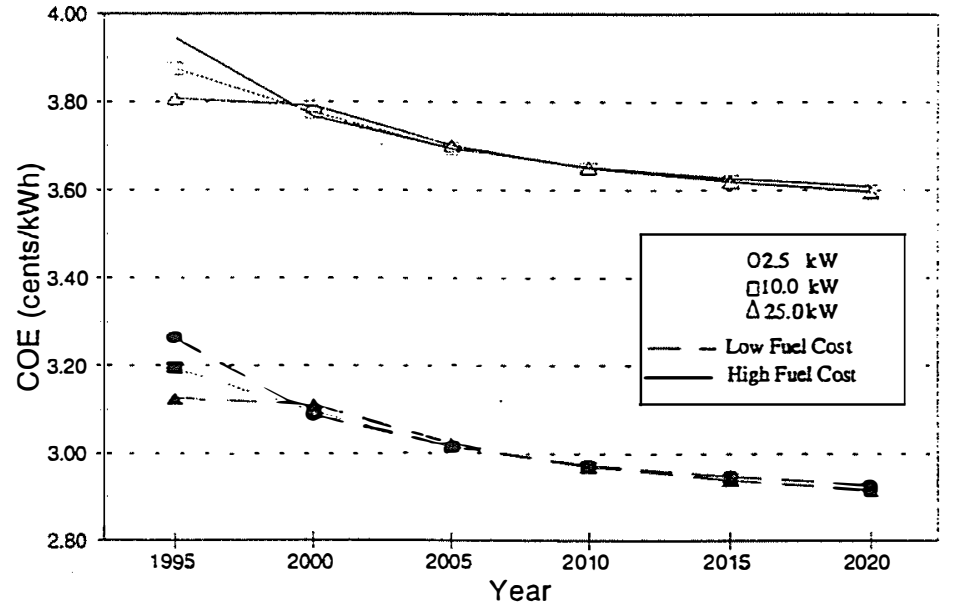

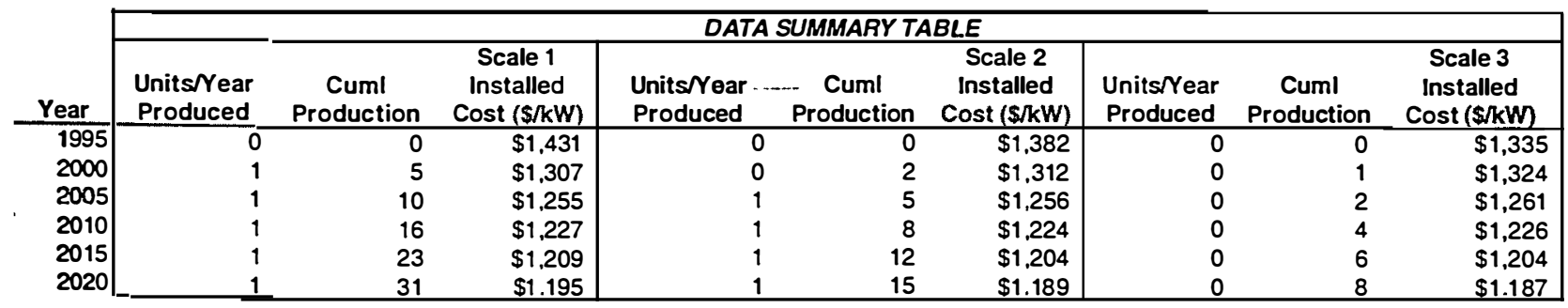

\begin{tabular}{|c|c|c|c|c|c|c|c|c|c|}
\hline \multirow[b]{3}{*}{ Year } & \multirow{3}{*}{$\begin{array}{c}\text { Scale 1 } \\
\text { Carrying } \\
\text { Chrg }(S / \mathrm{kW})\end{array}$} & \multirow{3}{*}{$\begin{array}{c}\text { Scale } 2 \\
\text { Carrying } \\
\text { Chrg }(\$ / k W)\end{array}$} & \multirow{3}{*}{$\begin{array}{c}\text { Scale 3 } \\
\text { Carrying } \\
\text { Chrg }(\$ / k W)\end{array}$} & \multicolumn{6}{|c|}{ Cost of Electricity Results (cents/kWh) } \\
\hline & & & & \multicolumn{2}{|c|}{ Scale 1 } & \multicolumn{2}{|c|}{ Seale 2} & \multicolumn{2}{|c|}{ Seale 3} \\
\hline & & & & $\begin{array}{c}\text { High } \\
\text { Fuel Cost }\end{array}$ & $\begin{array}{l}\text { Low } \\
\text { Fuel Cost }\end{array}$ & $\begin{array}{c}\text { High } \\
\text { Fuel Cost }\end{array}$ & $\begin{array}{l}\text { Low } \\
\text { Fuel Cost }\end{array}$ & $\begin{array}{c}\text { High } \\
\text { Fuel Cost }\end{array}$ & $\begin{array}{l}\text { Low } \\
\text { Fuel Cost }\end{array}$ \\
\hline 1995 & $\$ 155$ & $\$ 149$ & $\$ 144$ & 3.94 & 3.26 & 3.87 & 3.19 & 3.81 & 3.13 \\
\hline 2000 & $\$ 141$ & $\$ 142$ & $\$ 143$ & 3.77 & 3.09 & 3.78 & 3.10 & 3.79 & 3.11 \\
\hline 2005 & $\$ 136$ & $\$ 136$ & $\$ 136$ & 3.69 & 3.01 & 3.69 & 3.01 & 3.70 & 3.02 \\
\hline 2010 & $\$ 133$ & $\$ 132$ & $\$ 132$ & 3.65 & 2.97 & 3.65 & 2.97 & 3.65 & 2.97 \\
\hline 2015 & $\$ 131$ & $\$ 130$ & $\$ 130$ & 3.63 & 2.95 & 3.62 & 2.94 & 3.62 & 2.94 \\
\hline 2020 & $\$ 129$ & $\$ 128$ & $\$ 128$ & 3.61 & 2.93 & 3.60 & 2.92 & 3.59 & 2.91 \\
\hline
\end{tabular}




\section{Pulverized Coal Plant Projections \\ Transmission Cost Sensitivity}

- Plant Cost $(\$ / \mathrm{kW})$

Plant Size (kW)

Plant Heat Rate (Btu/kWh)

Capacity Factor

Generation (kWh/yr)

Fùel Costs (\$/MMBtu)

Levelized Capital Charges (\$)

Electricity theft

O\&M w/o Fuel Costs

Fuel Costs

Capital Charges

Total Busbar COE

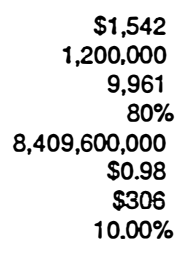

(cents/kWh)

0.435

0.976

0.044

1.455

\begin{tabular}{ccc}
$\begin{array}{c}\text { Line } \\
\text { Lenath }(\mathrm{km})\end{array}$ & $\begin{array}{c}\text { Cost } \\
\text { Sensitivity }\end{array}$ & $\begin{array}{c}\text { Delivered } \\
\text { Costs (cents/kWh) }\end{array}$ \\
\hline 0 & 0.00 & 2.587 \\
160 & 0.25 & 2.991 \\
360 & 0.50 & 3.395
\end{tabular}

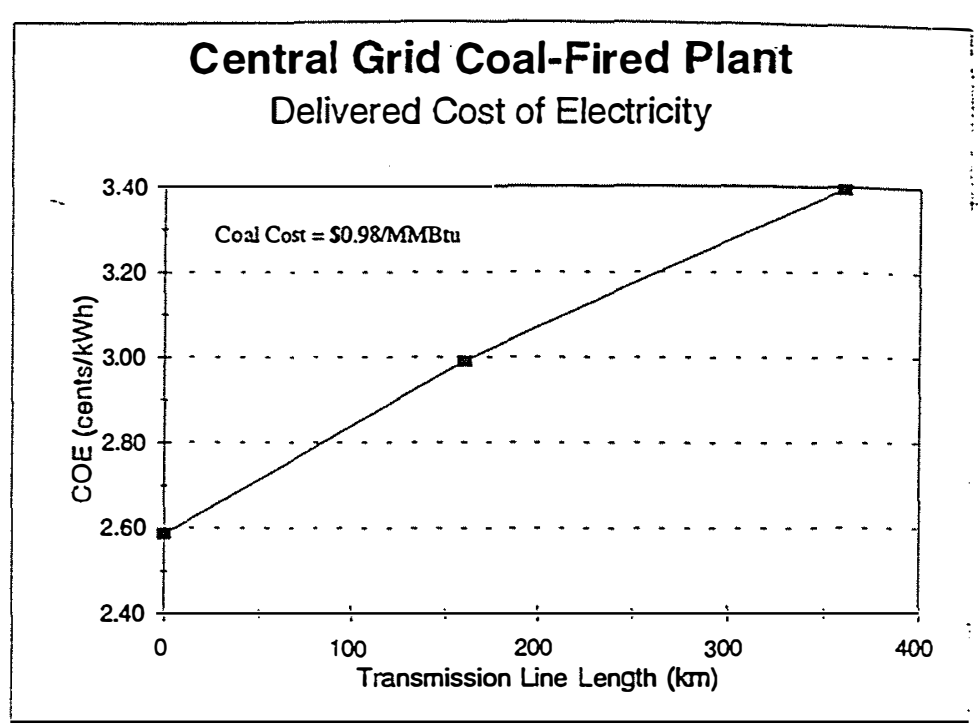

Carrving Charge Input Summary

Debt Interest Rate

Debt Fraction

Equity Cost

Equity Fraction

Construction Escalation Rate

Construction Time

Book Life

Depreciation Life

Additional Capital Charges

Property Tax \& Insurance

$12.00 \%$

$75.00 \%$

$22.00 \%$

$25.00 \%$

$4.50 \%$

0.5
30

Tax Rate

$2.00 \%$

$40.00 \%$ 


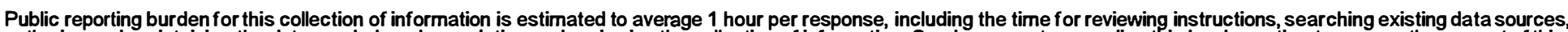

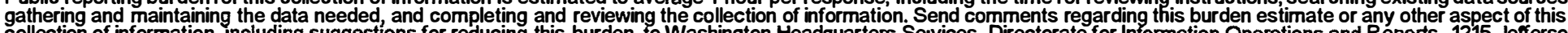

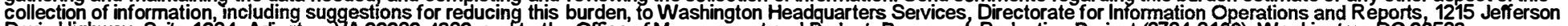

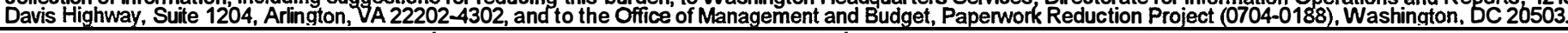
1. AGENCY USE ONLY (Leave blank)
2. REPORT DATE
May 1997

\section{REPORT TYPE AND DATES COVERED}
NREL Subcontract Report

\section{TITLE AND SUBTITLE}

Comparison of Large Central and Small Decentralized Power Generation in India
5. FUNDING NUMBERS

Task\#: BP711010

6. AUTHOR(S) C.P. Demeter, C.A. Lindsey,P.R. Shah

\section{PERFORMING ORGANIZATION NAME(S) AND ADDRESS(ES)}

Antares Group, Inc.

4351 Garden City Drive

Suite 301

Landover, MD 20785
9. SPONSORING/MONITORING AGENCY NAME(S) AND ADDRESS(ES)

National Renewable Energy Laboratory

1617 Cole Boulevard

Golden, CO 80401-3393
8. PERFORMING ORGANIZATION REPORT NUMBER

DE97000253

10. SPONSORING/MONITORING AGENCY REPORT NUMBER

NRELSR-430-22764

\section{SUPPLEMENTARY NOTES}

\section{2a. DISTRIBUTION/AVAILABILITY STATEMENT}

National Technical Information Service

U.S. Department of Commerce

5285 Port Royal Road

Springfield, VA 22161 12b. DISTRIBUTION CODE

UC-1310

13. ABSTRACT (Maximum 200 words) India is the second largest market in the world for new electricity capacity. Its total electricity consumption is expected to increase by $223 \%$ from 1995 to $2020 .^{\prime}$ In comparison, electricity consumption during the same period in the Organization for Economic and Cooperative Development Countries is expected to increase by only $58 \% .^{2}$ Currently, most of India's electricity consumers are in metropolitan areas; however, approximately $75 \%$ of the population lives in rural areas. This sector has benefited from the government's rural electrification programs, but most villages still face recurrent power shortages and some have no access to power. As a result, there is a substantial potential market for supplying reliable power to rural consumers.

\section{SUBJECT TERMS}

hydroelectric units, cogeneration units, power generation, central grid power
15. NUMBER OF PAGES 83

16. PRICE CODE

\section{SECURITY CLASSIFICATION OF REPORT}

\section{SECURITY CLASSIFICATION OF THIS PAGE}

19. SECURITY

CLASSIFICATION

OF ABSTRACT
NSN 7540-01-280-5500
Standard Form 298 (Rev. 2-85 Prescribed by ANSI Std. Z39-

${ }^{1}$ DRUMcGraw Hill, 1996, The Future of the Electric Power Industry, p. 112.

${ }^{2}$ EIA, 1996, International Energy Outlook 1996. 